\title{
MALAS PRÁCTICAS Y ACCIONES DE MEJORA EN EL TRIBUNAL DE DisTRITO DE LA INQUISICIÓN DE LLERENA
}

\author{
ISABEL MARTÍNEZ NAVAS \\ PROFESORA TITULAR DE HiSTORIA DEL DERECHO Y DE LAS INSTITUCIONES \\ UNIVERSIDAD DE LA RIOJA \\ isabel.mnavas@unirioja.es
}

SUMARIO: I. INTRODUCCIÓN. II. El CONTROL DE lOS TRIBUNALES DE DISTRITO. III. El TRIBUNAL DEL SANTO OFICIO DE LLERENA INSPECCIONADO. IV. RECOMENDACIONES, ADVERTENCIAS Y MEDIDAS PARA LA MEJORA DE LA PRAXIS INQUISITORIAL.

RESUMEN: Establecido en 1485, el Tribunal del Santo Oficio de Llerena fue objeto de diversas visitas de inspección en los siglos XVI y XVII. En ellas se determinaron y, en su caso, depuraron las responsabilidades en las que pudieron incurrir los integrantes del Tribunal por un incorrecto desempeño de sus funciones o por manifestar actitudes irreconciliables con las que debían acompañar a los servidores de la Inquisición. Al propio tiempo, las visitas de inspección arrojaron luz sobre posibles disfunciones y permitieron acometer las oportunas reformas con la vista puesta en corregir defectos de funcionamiento y procurar la deseada uniformidad en la práctica de los Tribunales de distrito.

Palabras Clave: Inquisición española, Santo Oficio de Llerena, Consejo de Inquisición, Visitas de inspección.

\section{Bad Practices and Corrective Measures in the Inquisition District TRIBUNAL OF LLERENA}

ABSTRACT: Established in 1485, the Tribunal of the Holy Office of the Inquisition of Llerena was the subject of numerous inspection visits in the 16th and 17th centuries; these inspections determined the accountability of the members of the Court for improper performance of their duties and/or for expressing attitudes irreconcilable with the morals and norms of the Office. With time, the inspection visits shed light on possible dysfunctions and led to the appropriate reforms with a view to correcting malfunctions and ensuring the desired uniformity in the practice of the District Courts.

KEYWORDS: Spanish Inquisition, Inquisition Council, Inspections visits, Holy Office of Llerena. 


\section{Introducción}

El estudio de los mecanismos de control de los Tribunales de distrito del Santo Oficio por parte del Consejo de Inquisición constituye un recurso imprescindible para reconstruir la historia de los diferentes Tribunales y sus protagonistas. Los minuciosos registros de los expedientes de visita general o particular, girados sobre aquellos en diferentes momentos, permiten obtener información muy precisa sobre el funcionamiento del Tribunal de que se trate y sus relaciones con otras instituciones. Buena prueba de las abundantes noticias que pueden extraerse a partir de las mismas es la atención prestada a las visitas por la historiografía inquisitorialista. Así, junto a los estudios monográficos atentos a los diferentes Tribunales, en los que constituyen, habitualmente, referencia obligada las visitas de que fueron objeto, han ido dándose a la luz un buen número de estudios particulares sobre uno o varios de esos expedientes de control de los Tribunales de distrito. Con todo, como se advertía hace más de treinta años ${ }^{1}$, son aún pocos los estudios de conjunto de la visita de los Tribunales inquisitoriales. A los publicados en los años de despegue del interés por el estudio del Santo Oficio, a cargo de Bennasar, Balancy o Alonso, poco se ha añadido después. Es por ello que, desde hace un tiempo, he centrado la atención en la conclusión de un estudio general de la visita inquisitorial, sobre su naturaleza, regulación, desarrollo y resultados, que exige la revisión de una ingente documentación correspondiente a visitas de cada uno de los Tribunales del Santo Oficio.

Si atendemos ahora en particular a la Inquisición de Llerena, es claro que, del mismo modo que en relación a otros Tribunales de distrito, los expedientes de visita no han pasado inadvertidos a los estudiosos del Santo Oficio extremeño. Junto a algunas noticias particulares que salpican los trabajos atentos al funcionamiento del Tribunal de Llerena, merece atención destacada, al objeto de lo que aquí me propongo, un trabajo, publicado hace cerca de dos décadas, en el que se aborda el estudio de las diferentes visitas de que fue objeto el Santo Oficio llerenense en los siglos XVI y XVII 2 . El análisis realizado por su autor, así como los datos extraídos de la aproximación a la amplísima documentación conservada en el Archivo Histórico Nacional, me permitirá abordar la redacción del apartado de este trabajo atento a las inspecciones giradas sobre el Tribunal de Llerena. De otra parte, el relativo a la visita en general -que no pretende ser más que una breve aproximación introductoria a la visita de los Tribunales de distrito del Santo Oficio- se ha construido, sobre todo, a partir de las diferentes aportaciones realizadas por la doctrina especializada. Finalmente, el último apartado, el que constituye el núcleo central de este trabajo, se construye fundamentalmente a partir de la voluminosa documentación que se conserva sobre estas visitas al Tribunal de Llerena.

\footnotetext{
${ }^{1}$ En este sentido, ALONSO, M.L., "La revisión del proceso inquisitorial según las visitas generales", en ESCUDERO, J A. (edit.). Perfiles jurídicos de la Inquisición Española, Madrid, Instituto de Historia de la Inquisición, 1983, pp. 323-343.

2 FERNÁNDEZ NIEVA, J., "Inquisición interactiva. Inquisición e inquisidores llerenenses en los siglos XVIXVII”, en Revista de Estudios Extremeños, 56, 1 (2000), pp. 161-192.
} 


\section{El control de los tribunales de distrito}

La visita constituye probablemente el más eficaz medio de control de los Tribunales por parte del Consejo de la Santa, General y Suprema Inquisición. Inquisidor general y Consejo disponen también de otros mecanismos que les permiten conocer $y$, en su caso, encauzar o redirigir si fuese necesario la actuación de quienes forman parte de la más cercana y visible Inquisición ${ }^{3}$. De este modo, a través de Instrucciones y Cartas acordadas, establecen el marco en el que deben moverse los diferentes Tribunales ${ }^{4}$. Ocasionalmente, además, se dirigen a uno o varios Tribunales de distrito -de los que se tiene noticia de que existe o podría llegar a existir algún problema- participándoles su voluntad de que tal situación se resuelva o no llegue a producirse y señalando la vía adecuada por la que debe discurrir la práctica del Santo Oficio. Por otra parte, la obligación que pesa sobre los Tribunales de reportar periódicamente al Consejo el estado en que se encuentra el despacho de las causas pendientes, o de que sus cuentas pasen por la correspondiente Junta de hacienda, permite a la cúpula inquisitorial conocer bien cómo discurre la actividad ordinaria del amplio número de Tribunales de distrito5. Con todo, la mala praxis $\mathrm{y}$, por ende, la responsabilidad de los que incurren en ella, no resultaría extraña si se escrutaba con detenimiento la actuación de un amplio grupo de personas dotadas de una posición privilegiada en el ámbito en el que desarrollan las funciones que se les han cometido. Y en estos casos era precisa la intervención de la cúpula inquisitorial. No siempre sería necesaria, claro está, una visita general del Tribunal. En ocasiones, el problema detectado, o la sospecha, se circunscribía a uno o varios de sus integrantes, recurriéndose entonces al traslado de un inquisidor, que se integraba o no en la planta del Tribunal por el tiempo que fuese preciso y cuya misión era averiguar qué ocurría e informar al Consejo ${ }^{6}$. En otros casos,

3 Sobre el control de los Tribunales de distrito en el período de mandato de los sucesivos inquisidores generales, GALVÁN RODRÍGUEZ, Eduardo, El Inquisidor General, Madrid, 2010.

${ }^{4}$ DOMÍNGUEZ NAFRÍA, J.C., "Las Instrucciones como fuente del derecho inquisitorial”, en ESCUDERO, J.A. (coord.), Intolerancia e Inquisición. Actas del Congreso Internacional de Intolerancia e Inquisición celebrado en Madrid y Segovia en febrero de 2004, 3 vols., Madrid, 2006, I, pp. 455-493; Sobre Cartas acordadas, provisiones y otras normas emanadas de la Inquisición española, PÉREZ FERNÁNDEZ-TURÉGANO, C., "Cartas acordadas de la Inquisición española", en Revista de la Inquisición, Intolerancia y Derechos Humanos, 21 (2017), pp. 13-34; CABEZAS FONTANILLA, S., "La carta acordada: nacimiento y consolidación de un documento inquisitorial", en Hidalguía, 294 (2002), pp. 713-726; GALENDE DÍAZ, J.C., "Documentación legislativa del Santo Oficio: las provisiones", en Littera scripta in honorem prof. Lope Pascual Martínez, 2 vols., Murcia, 2002, I, pp. 341-348.

5 Para H. Ch. LEA, esto habría llevado a que el número de visitas fuese disminuyendo. A mayor centralización, menor necesidad de inspección de los Tribunales inferiores, señalaba el historiador norteamericano en Historia de la Inquisición Española, 3 vols., Madrid, Fundación Universitaria Española, 1983, II, 89.

${ }^{6}$ En 1631, el Consejo dispuso que un inquisidor de Sevilla "vaya a residir en esa Inquisición [de Llerena] por algún tiempo y ha parecido que, aunque es más nuevo, tenga ahí el mejor lugar en todas las Juntas y actos públicos donde el Tribunal se juntare y que con él se observe este estilo mientras ahí estuviere". El mismo día, se había despachado comisión al inquisidor sevillano "para que hagáis en la Inquisición de Llerena las diligencias que en otra se os avisa y también una carta para los inquisidores de allí dándoles aviso de cómo vais a residir por algún tiempo en aquella Inquisición". Junto a la comisión se le remitieron además los memoriales que se habían recibido contra los ministros que resultaban sospechosos de excesos y de encuentros y diferencias entre ellos, AHN, Inquisición, lib. 593, ff. 50r-51r, "Forma de despacho cuando se envía a un Inquisidor que haga alguna averiguación o información en alguna Inquisición, fuera de visita". A las visitas y estas otras inspecciones particulares se refiere E. BALANCY, para quien estas últimas responden a situaciones de extraordinaria urgencia y que requieren máxima discreción. Menciona, en particular, la comisión otorgada, en 1581, a un inquisidor sevillano -a quien veremos después actuar también como visitador en Llerena- para inspeccionar a un 
sin embargo, se resolvía despachar una visita general. Era entonces cuando el visitador debía ocuparse en el análisis pormenorizado de lo hecho o dejado de hacer por inquisidores, fiscal, notarios y los restantes oficiales y personal al servicio del Santo Oficio en un determinado Tribunal ${ }^{7}$. La lente cercana aplicada con precisión sobre los mismos hacía aflorar defectos en su actuación de diferente gravedad y el Consejo procedía posteriormente a la depuración de las responsabilidades en las que se hubiere incurrido, reprendiendo, imponiendo multas, e incluso separando de su empleo a los que habían resultado culpados ${ }^{8}$.

La visita de los Tribunales del Santo Oficio no fue regulada en las Instrucciones, con la única excepción que representa el mandato, contenido en las conocidas como Instrucciones antiguas, de que se designasen anualmente dos visitadores cuya misión consistía en inspeccionar todos los Tribunales, dando cuenta al Consejo de la situación de los mismos ${ }^{9}$. De hecho, como ocurrió también con otros expedientes de control conocidos en relación a la Administración y oficiales reales, la visita del personal al servicio del Santo Oficio no llegó a tener un carácter periódico y regular ${ }^{10}$. Antes bien, respondió generalmente a la existencia previa de cierta sospecha, o de la evidencia, revelada por una denuncia, que afectase a un Tribunal en su conjunto o a algunos de sus individuos. No contamos, en todo caso, con una definición legal de estos mecanismos de control de carácter extraordinario ${ }^{11}$, pero es posible convenir que se trata, en efecto, de procedimientos de inspección del aparato del Santo Oficio, de carácter no regular y que tienen por objeto conocer el estado del Tribunal y detectar, en su caso, posibles disfunciones en su funcionamiento, estableciendo las medidas necesarias para su corrección.

En la visita intervienen, de una parte, la cúpula de la estructura inquisitorial, esto es, el inquisidor general y el Consejo, que actúan como órganos impulsor y decisor del procedimiento. En segundo término, los protagonistas de la misma y los llamados a testificar en el marco de la visita. Finalmente, los instructores del expediente: el comisionado por el inquisidor general para llevar a cabo la inspección y el secretario de la

inquisidor y un notario de la Inquisición de Córdoba, “L'Inquisition devant le miroir (1562-1648)", en Mélanges de la Casa de Velázquez, 27-2 (1991), Epoque moderne, pp. 33-34.

7 BENNASSAR, B., "Le controle de la hierarchie: les inspections des envoyes de la Supreme aupres des tribunaux provinciaux”, en PÉREZ VILLANUEVA, J., La Inquisición Española. Nueva visión, nuevos horizontes, Madrid, Siglo XXI ed., pp. 887-891.

${ }^{8}$ Buena parte de los estudios sobre las inspecciones de los Tribunales inquisitoriales coinciden en el escaso rigor con el que fueron sancionados los ministros y oficiales que resultaron culpados en las mismas. Así, por todos, ALONSO, M.L., "La revisión del proceso inquisitorial según las visitas generales", en Perfiles jurídicos de la Inquisición española, cit., pp. 329-330; GALVÁN, E., El Inquisidor General, cit., p. 339.

${ }^{9}$ Cito por la reciente edición a cargo de DOMÍNGUEZ NAFRÍA, J.C., "La «copilación» de las instrucciones inquisitoriales de Gaspar Isidro de Argüello", en Revista de la Inquisición, 12 (2006), pp. 137-276, p. 240.

10 Sobre la rendición de cuentas al término del empleo que representa el conocido juicio de residencia, o las inspecciones de determinados oficiales o instituciones en forma de pesquisas y visitas, GONZÁLEZ ALONSO, B., "Los procedimientos de control y exigencia de responsabilidad de los oficiales regios en el Antiguo Régimen (Corona de Castilla, siglos XIII-XVIII)", en Anuario de la Facultad de Derecho de la Universidad Autónoma de Madrid, 4 (2000), pp. 249-272. Por lo que se refiere a la naturaleza de la visita de inspección de los Tribunales inquisitoriales, García Cárcel y Moreno apuntan que se trata de un expediente de control calcado del modelo pontificio de los inquisidores apostólicos, GARCÍA CÁRCEL, R. y MORENO, D., Inquisición. Historia crítica, Madrid, 2000, p. 119.

11 En este sentido, en relación a las visitas de los oficiales reales, GARRIGA, C., La Audiencia y las Chancillerías castellanas (1371-1525), Madrid, Centro de Estudios Políticos y Constitucionales, 1994, p. 425. 
misma. En relación a los visitadores, las Instrucciones de 1498 -a las que me he referido antes- precisaban que debía tratarse de una "buena persona, de letras y conciencia, y edad, que visite todas las Inquisiciones y traya verdadera información de cada vna de ellas, del estado en que están, para que se pueda proeuuer lo que conuiniere”. La práctica posterior las muy numerosas visitas desarrolladas en los siglos XVI y XVII- permite establecer un perfil del visitador algo diferente. No se tratará ya de un inspector designado con carácter general para la visita de unos u otros Tribunales como el inicialmente descrito en las Instrucciones, sino de un buen conocedor de la organización y funcionamiento del Santo Oficio, al que se designa para llevar a efecto una inspección determinada ${ }^{12}$. Encontramos así al frente de estas inspecciones a miembros del Consejo o, en la mayor parte de los casos, a inquisidores que desempeñan su función habitualmente en distritos próximos al visitado, o que han formado parte de la planta del mismo en un momento anterior. Por lo que se refiere al secretario de la visita, el nombramiento recae en el notario del Santo Oficio propuesto por el visitador, primando probablemente la relación de confianza entre ambos como criterio de selección ${ }^{13}$.

La visita comienza en el momento en que por parte del inquisidor general y el Consejo de Inquisición se decide llevar a efecto la inspección y se procede al nombramiento del visitador. El inquisidor elegido recibe la correspondiente "carta de comisión", esto es, una provisión validada con la firma del inquisidor general y señalada por los miembros del Consejo, a través de la que se confiere al visitador el poder suficiente para llevar a cabo la inspección ${ }^{14}$. Designado asimismo el secretario y formalizada por ambos la aceptación de la comisión que se les ha conferido, se pondrían en camino hacia la sede del Tribunal que debían visitar. Llegados al lugar, previa la oportuna convocatoria, reunirían a los miembros del Tribunal y les darían a conocer la provisión de sus nombramientos, recabando su acatamiento por el Tribunal. A partir de ese momento tendría lugar el inicio del trabajo de inspección que se les había encomendado y que se articularía en tres fases: la inicial y generalmente más dilatada, correspondiente a la instrucción, la fase contradictoria y la de decisión.

En la fase de instrucción, el órgano impulsor del procedimiento es el visitador, quien, generalmente, cuenta con información previa que le permite organizar la investigación. La práctica establece de forma precisa cómo debe llevar a cabo las sucesivas actuaciones y

12 Como explicó LEA, las primeras noticias acerca de visitadores corresponden al período de generalato de Torquemada. Después, tras las Instrucciones de 1498 se conoce el nombramiento de algunos inspectores y en 1517 parece haberse recurrido, tanto en Castilla como en Aragón, a comisionar para la visita de varios Tribunales cercanos entre sí a un inquisidor de otro Tribunal asimismo próximo. Tras la reunificación de la Inquisición, la novedad advertida por este autor sería la designación de inspectores laicos a los que, según indica, se habrían ampliado sus facultades, Historia de la Inquisición Española, cit., pp. 86-87.

13 Acerca del papel asignado a los secretarios en las visitas, SANTIAGO MEDINA, B., La burocracia inquisitorial: escrituras y documentos. Tesis doctoral. Universidad Complutense de Madrid, 2016, pp. 111-117. Da cuenta también, de cómo se procede al nombramiento y aceptación por parte del secretario. Erróneamente indica que no era habitual que visitador y secretario procediesen del mismo Tribunal, ibídem, p. 114. Sin embargo -como después se verá en el caso de Llerena-, ésta parece ser una práctica frecuente.

14 Se trataba de documentos suscritos por el inquisidor general y sellados con su sello personal, según explican GALENDE DÍAZ, J.C. y SANTIAGO MEDINA, B., "La atípica visita a la Inquisición de Córdoba en 1597. Un ejemplo de la vigilancia de la Suprema sobre los Tribunales de distrito”, en Legajos, 11 (2009), f. 39. 
cómo deben documentarse cada una de ellas ${ }^{15}$. De este modo, visitador y secretario proceden al examen del Secreto del Tribunal, prestan especial atención a la situación de las causas despachadas y en tramitación, inspeccionan la cárcel, interrogan a los presos y al alcaide, y proceden al examen de los inquisidores y del resto del personal que desempeña su función al servicio del Tribunal. Esto último constituye, sin duda, el grueso de la visita. Ante el visitador y el secretario van desfilando los diferentes integrantes del Tribunal y sus servidores y un número más o menos amplio de testigos que concurren espontáneamente o son llamados por el visitador. Si lo estima necesario, el visitador recaba también la colaboración de otros individuos o instituciones a los que no es posible convocar a su presencia por encontrarse en otras localidades.

La fase de instrucción concluye con la formación del correspondiente pliego de cargos generales y particulares y con su traslado a los inicialmente inculpados. A partir de este momento, se desarrolla la fase contradictoria. Generalmente más breve, se circunscribe a la recepción por parte del visitador, dentro del término señalado por éste, de los descargos formulados por los inculpados y al examen de los testigos propuestos para su defensa. Asimismo, se practican las restantes pruebas propuestas, recabando, en su caso, documentación procedente del propio Tribunal o de fuera de éste. Esta segunda fase concluiría con la redacción de una suerte de informe general de la visita, en el que se detallarían los cargos generales y particulares y, en su caso, el resto de circunstancias que se hubieren conocido a partir de la inspección.

La fase decisoria arrancaría así con la recepción por parte del Consejo del expediente de la visita. A partir del mismo, a la vista de los hechos que resultaban probados, determinada la responsabilidad en la que habían incurrido los culpados, se procedía a señalar las sanciones disciplinarias correspondientes, dejándose abierta, en su caso, la vía penal ${ }^{16}$. Al propio tiempo, el resultado de la inspección permitía al inquisidor general y el Consejo emprender cuantas "acciones de mejora" de la institución reclamase la información obtenida acerca de sus disfunciones ${ }^{17}$. Y siempre sin estrépito. Las sanciones no eran, generalmente, muy rigurosas, prefiriéndose el traslado o la jubilación del que actuaba

15 Las diferentes actuaciones emprendidas por el visitador fueron apuntadas por LEA, H.Ch., Historia de la Inquisición, cit., II, pp. 88-89. Más extensamente, en relación a una “visita-tipo", BALANCY, E., "L'Inquisition devant le miroir (1562-1648)", cit., pp. 34-45.

16 La resolución adoptaba la forma de una Provisión del inquisidor general, señalada asimismo por el Consejo: "Nos el maestro fray Luis Aliaga, por la gracia de Dios, inquisidor apostólico general en los Reinos y Señoríos de Su Magestad, su confesor y de su Consejo de Estado, \&. A vos, los licenciados [...], inquisidores apostólicos contra la herética pravedad y apostasía en la Provincia de León y su distrito, en la Visita que en ese Santo Oficio hizo, por comisión nuestra, el doctor [...] y hauiéndose comunicado con nos, ha parecido que, para la buena administración de la Justiçia y breve expedición de los negoçios y causas que en esa Inquisiçión se trata y de aquí adelante se trataren; y para corregir y enmendar los cargos y culpas que de la dicha Visita resultan contra vos y algunos de los ministros y ofiçiales de esa Inquisiçión, conviene proveer en las cosas y cargos siguientes: [...] Por ende, por el tenor de la presente, encargamos y mandamos a vos los dichos inquisidores y a los ofiçiales de esa Inquisiçión, que veáis esta nuestra Provisión y los capítulos en ella contenidos y los guardéis, cumpláis, guarden y cumplan en lo que a cada uno de vos y de ellos toca y taña, en todo y por todo según y como en ellos se contiene, con apercibimiento que, si lo contrario se hiçiere, proveeremos cerca de ello [...] Dada en la çiudad de Madrid, a [...]Por mandado de su Ilustrísima, Hernando de Villegas. Señalada de los Señores del Consejo [...]”, AHN, Inquisición, lib. 592, ff. 202r y 262 vo.

${ }^{17}$ La decisión de modificar la estructura o funcionamiento de los Tribunales como resultado de lo observado en una visita podía adoptarse tiempo después. En forma de carta acordada, provisión o en su caso a partir de los llamados "capítulos de visita". Me ocupo de esto en el último apartado de este trabajo. 
incorrectamente a su suspensión del empleo. Tampoco el propio procedimiento debía causar inquietud o escándalo, por lo que en los casos de claros incumplimientos se procedía por vía de gobierno y en aquellos en los que resultaba imprescindible mayor averiguación se optaba por acotarla lo más posible. "La experiencia ha mostrado -señalará un informe remitido al inquisidor general Arce de Reinoso ${ }^{18}$ - que la [visita] general es medio ruidoso y, en perjuicio de la veneración del Oficio, da lugar a chismes y bandos".

\section{El Santo Oficio de Llerena inspeccionado}

El Tribunal del Santo Oficio extremeño tuvo su sede en Llerena desde 148519. Los expedientes conservados en el Archivo Histórico Nacional, que forman parte de la subserie "Visitas al Tribunal de la Inquisición de Llerena", corresponden a ocho visitas realizadas en los siglos XVI y XVII y una pesquisa llevada a cabo en la mitad de este último, en la que resultaron investigados los inquisidores y el fiscal llerenenses ${ }^{20}$. A éstas, debemos sumar otra visita girada en 1604 -de la que únicamente he localizado lo resuelto, en el año siguiente, por el Consejo en relación a los cargos por los que resultaron culpados los integrantes del Tribunal extremeño en la que será la primera de las numerosas inspecciones de que fue objeto durante el siglo XVII ${ }^{21}-\mathrm{y}$, asimismo, otras visitas particulares que tuvieron por objeto averiguar los excesos y diferencias habidas entre varios miembros del Tribunal del Santo Oficio de Llerena ${ }^{22}$.

De este modo, la primera de las visitas habría tenido lugar en 1565 y la última registrada lo habría sido entre 1696 y 1697, habiéndose desarrollado el grueso del conjunto de las inspecciones giradas sobre el Tribunal de Llerena en la primera mitad del siglo XVII, en la que se habrían sucedido las realizadas en 1604, 1619-20, 1623, 1633, 1639 y $1643-$ $44^{23}$. Buena parte de ellas han sido ya estudiadas -bien que de forma parcial-, de manera

18 BN, Mss. 7669, ff. 79vo-120r, cit. por GALVÁN, E., El Inquisidor General, cit., pp. 360-361.

19 El Tribunal del Santo Oficio extremeño comenzó su andadura, en 1484, en la villa de Guadalupe, estableciéndose, en el año siguiente en Llerena. GARRAÍN VILLA, L.J., “Orígenes del Santo Oficio de la Inquisición de Llerena", en Actas II Jornada de Historia de Llerena, Llerena, 2001, pp. 117-133.CASO AMADOR, R. y GARRAÍN VILLA, L.J., "Aportación al estudio de los orígenes del Tribunal de la Inquisición de Llerena”, en LORENZANA DE LA PUENTE, F., MATEOS ASCACÍBAR, F.J. e IÑESTA MENA, F. (coords.), Actas de las XIII Jornadas de Historia en Llerena, Llerena, Sociedad Extremeña de Historia, 2012, p. 285.

${ }^{20} \mathrm{http}: / /$ pares.mcu.es/ParesBusquedas/servlets/Control_servlet?accion=3\&txt_id_desc_ud=7014140\&fro magenda= $\mathrm{N}$ [consultado: 20/08/2019]

${ }^{21}$ La Provisión de resolución de la visita de 1605 se localiza en AHN, Inquisición, lib. 367, ff. 19r-72vo. Me he ocupado de su transcripción y estudio con ocasión de las Jornadas sobre la Inquisición Española, "El Tribunal inquisitorial de Llerena y su jurisdicción en Extremadura”, celebradas recientemente en Cáceres.

22 Por orden cronológico, "Pesquisa contra Francisco Ibáñez, receptor del Tribunal de la Inquisición de Llerena, 1577”, en AHN, Inquisición, leg. 1989, exp. 5; Comisión otorgada por el inquisidor general Pacheco a Agustín Ugarte Saravia, 1622, en AHN, Inquisición, lib. 592; Comisión al inquisidor Bernardo de la Cabra, inquisidor apostólico de la ciudad de Sevilla, para la averiguación de los excesos y desencuentros entre inquisidores y notarios del Secreto de la Inquisición de Llerena, año 1631, en AHN, Inquisición, lib. 593; y la ya mencionada antes -incluida en la subserie "Visitas" -, "Pesquisa contra los inquisidores D. Xtobal Serrano Osorio, D. Pedro Llerena Bracamonte, el Dr. Alonso Freyre, fiscal y D. Lorenço Balberde, notario del Secreto, 1643”, AHN, Inquisición, legs. 1990, 1991 y 1993.

${ }^{23}$ He localizado asimismo documentación relativa a una visita particular al fiscal del Tribunal de Llerena, correspondiente a los primeros años del siglo XVIII. 
que se conocen desde hace tiempo el contexto en el que tuvieron lugar, algunos datos significativos en relación a su despliegue y, en algún caso, el alcance de los cargos formados a los inquisidores que en cada momento conformaban el elemento dotado de jurisdicción dentro del Tribunal de Llerena ${ }^{24}$. La revisión que planteo ahora de las nueve inspecciones mencionadas persigue obtener una imagen dinámica -aunque necesariamente distorsionada ${ }^{25}$ - de la Inquisición de Llerena y de la ordenación de su funcionamiento.

\section{III.1. Las primeras visitas del Tribunal de Llerena}

La primera de las visitas documentada tuvo lugar en 1565. La razón de ser de la misma fue -a decir de la cúpula inquisitorial- la existencia de numerosas irregularidades en el Santo Oficio de Llerena: procesados que no debían haberlo sido por falta de competencia de la Inquisición, prisiones efectuadas sin dar cuenta de ello al Consejo "contra el estilo y costumbre e Instrucciones del Santo Oficio" y la celebración de un Auto de fe, el 8 de abril de 1565, "sin dar noticia alguna al Consejo de la General Inquisición". A esto debía sumarse como detallaba la información suministrada al visitador acerca de lo que debía tener presente en la Visita ${ }^{26}$ - el incumplimiento de órdenes expresas recibidas del Consejo, hasta en tres ocasiones, relativas a la obligación de llevar a cabo la visita por el distrito, en particular en lo tocante a la ciudad de Plasencia y su Obispado.

El designado para acometer la inspección del Tribunal de Llerena fue un inquisidor de Córdoba y buen conocer del Santo Oficio extremeño, en el que había ejercido como inquisidor dos décadas atrás ${ }^{27}$. La comisión para la visita fue formalizada, el 20 de abril de 1565, por el inquisidor general Valdés, comunicándose a las miembros del Tribunal de Llerena el 9 de mayo ${ }^{28}$. Aceptada la comisión por parte del visitador, designado como secretario un notario del secreto procedente asimismo de la Inquisición de Córdoba y formalizado el acatamiento de la provisión que se les había notificado por parte del personal al servicio de la Inquisición de Llerena, poco después comenzó a tomarse declaración a los investigados y a diferentes testigos que fueron llamados por el visitador en atención a la "relación que tuvo Su Merced de esto", o que comparecieron espontáneamente para declarar acerca de la actuación de unos u otros ${ }^{29}$. El interrogatorio de algunos testigos hizo precisa además la colaboración de otros Tribunales u oficiales, otorgándose al efecto el

\footnotetext{
24 FERNÁNDEZ NIEVA, J., “Inquisición interactiva...”, cit., p. 168 y 184.

25 Como advierte J. CONTRERAS, el resultado del escrutinio que representaba la visita ofrece una imagen de un Tribunal concreto que responde a una situación excepcional, no a la normal y cotidiana actuación del conjunto de los Tribunales, El Santo Oficio de la Inquisición en Galicia: 1560-1700. Poder, sociedad y cultura, Madrid, ed. Akal, 1982, p. 307.

26 "Las cosas a qe a de aduertir el Lizdo Villar, inquisidor apostólico de la ciudad de Córdoua, en la Vissita qe a de hazer de inquisidores y offiçiales de la prouinçia de León, en la villa de Llerena", AHN, Inquisición, leg. 1989, exp. 1, ff. $1 \mathrm{r}-2 \mathrm{r}$.

27 El Licenciado Martín Villar recibió comisión del inquisidor general Valdes para visitar el Santo Oficio de Llerena. Como secretario de la visita fue elegido Sebastián Camacho.

28 Un traslado de la provisión del inquisidor general Valdés, inserta en el acta de la diligencia de su comunicación al Tribunal de Llerena, en ibídem, ff. 3r-ํo.

${ }^{29}$ Compareció así, por ejemplo, espontáneamente un testigo que manifestó conocer la animadversión de los miembros del Tribunal hacia uno de los inquisidores, en ibídem, ff. 210r-211r.
} 
correspondiente poder por parte del visitador, al tiempo que facilitaba las preguntas por las que debían ser interrogado ${ }^{30}$.

Al propio tiempo se inspeccionaron, como marcaba el orden que debía seguirse en las visitas de los Tribunales inquisitoriales, el archivo o Secreto del Tribunal y sus cárceles. La visita de éstas implicaba, de una parte, la revisión del "Libro de visita de las cárceles", que debía custodiarse en la Cámara del Secreto y en el que quedaban reflejadas las diligencias de visita a que venían obligados los inquisidores ${ }^{31} \mathrm{y}$, de otro lado, la inspección del estado de los presos recluidos en las mismas y de la actuación de los oficiales que se encargaban de ellos. Con esta finalidad, fueron interrogados más de un centenar de personas -sesenta y un presos en la cárcel secreta y cincuenta y dos en la visita de la cárcel de penitencia-, adoptándose, seguidamente -como después se verá- decisiones que se consideraron inaplazables para favorecer la mejora de la situación en las cárceles. En la visita de la Cámara del Secreto, por su parte, se incidió fundamentalmente en la revisión de las causas despachadas por los inquisidores, sobre las que existían sobrados motivos de sospecha de haberse actuado incorrectamente ${ }^{32}$.

Al término de la inspección -que se extendió a lo largo de más de medio año-, los cargos formados a los integrantes del Tribunal de Llerena fueron muy numerosos y, en algún caso, de extraordinaria gravedad. Así, junto a las habituales llamadas de atención sobre incumplimientos varios relativos a la no lectura anual de las Instrucciones y Cartas acordadas, la no realización de la visita del distrito o de las cárceles, el retraso en el despacho de las causas, o la falta de asistencia o la existencia de tensiones entre los miembros del Tribunal que dificultaban su buen funcionamiento, el expediente remitido por el inquisidor-visitador al Consejo contenía otros extremos, de mayor gravedad, imputados a los inquisidores, tales como irregularidades en el despacho de los mandamientos de prisión, en el desarrollo de las causas y en la práctica del tormento. En particular, esto último debió causar gran alarma al Consejo, que no dudó en sancionar, por esta razón, con un rigor poco habitual, al inquisidor que finalmente resultó culpado, a pesar de la insistencia por parte del mismo en que constituía una práctica habitual en el Santo Oficio ${ }^{33}$. La resolución, fechada en 1566, suspendió de su empleo a uno de los inquisidores y al alguacil del Tribunal de Llerena ${ }^{34}$.

La segunda de las visitas giradas sobre el Tribunal de Llerena se llevó a efecto veinte años más tarde ${ }^{35}$. En esta ocasión se designó como visitador a un inquisidor del Santo Oficio

${ }^{30}$ A instancia del visitador, se requirió la colaboración de otros Tribunales, AHN, Inquisición, leg. 1989, exp. 1, ff. 647r-676r y 692r-694r. Asimismo recabó esa ayuda, más adelante, cuando fue preciso interrogar a algunos testigos propuestos por los inculpados en apoyo de su defensa, AHN, Inquisición, leg. 1989, exp. 4.

${ }^{31} \mathrm{AHN}$, Inquisición, leg. 1989, exp. 13.

32 En ibídem, pueden verse diversos traslados de documentos del Secreto utilizados por el visitador para documentar los cargos formados en la visita. Se trata de información extraída del "Libro de visitas de las cárceles" y de diferentes causas de fee.

33 Una minuta de la provisión de resolución de la Visita, en AHN, Inquisición, leg. 1989, exp. 3, ff.1-17. Sobre los excesos del inquisidor Del Moral, FERNÁNDEZ NIEVA, J., cit., pp. 176-179.

${ }^{34}$ AHN, Inquisición, lib. 575, ff. 389-400.

35 Entre ambas habrían tenido lugar, por una parte, la inspección particular llevada a cabo un inquisidor del Tribunal de Logroño, en 1574; y, tan sólo tres años más tarde, la que corrió a cargo de uno de los propios 
de Sevilla ${ }^{36}$, al que encontraremos, dos años más tarde, también ejerciendo esa función inspectora en Córdoba ${ }^{37}$. De esta segunda visita general al Tribunal de Llerena se han conservado dos voluminosos expedientes que permiten reconstruir la inspección desde el momento en que se toma la decisión de ponerla en marcha -comisión otorgada al visitador e interrogatorio general para la visita ${ }^{38-}$, hasta su conclusión por el visitador interrogatorios a miembros del Tribunal de Llerena y a otros testigos, índice de cargos y descargos, documentación correspondiente a la práctica de la prueba, descargos presentados por los inculpados, o relación enviada por el visitador al Consejo haciéndoles partícipe de los extremos que precisaban reformas en la Inquisición extremeña ${ }^{39}$-. No se ha conservado, sin embargo, la provisión de resolución de esta visita, debiendo servirnos tan sólo de la nada desdeñable información suministrada por la amplísima documentación de traslado de los cargos y los descargos que en su favor presentan los inculpados y con el interesante informe remitido al Consejo por el visitador al finalizar su trabajo ${ }^{40}$.

Nada indica la misiva con la que se remite su título al visitador, el 2 de marzo de 1585, que nos permita conocer la razón de ser de la visita: "Por algunos justos respectos a paresçido que conbiene embiar a visitar los Inquisidores y oficiales de la Inquisiçion de Llerena", se indica sin mayores precisiones. Tampoco consta que se pusiese a disposición del visitador información adicional al respecto. A tenor de la investigación realizada por el visitador y su secretario, en los más de seis meses que duró la visita, la conducta y ejercicio de los inquisidores y de los restantes miembros del Tribunal parecía, con alguna excepción, adecuada a los requerimientos de sus respectivos empleos. De este modo, a pesar de que, en efecto, al finalizar la instrucción se formularon diferentes cargos a buena parte de los servidores del Santo Oficio de Llerena, el propio visitador no ocultará la buena impresión que le han causado la práctica totalidad de ellos considerados individualmente. Las expresiones con las que se refiere a los mismos son suficientemente expresivas: "Hábil y entiende bien los negocios de Inquisición. Está bien instruido en los de la Inquisición de Llerena", dirá al hablar del fiscal; Honrados, bien compuestos y de buena condición para Inquisidores, señala al referirse a los dos inquisidores más antiguos del Tribunal; buen oficial, gran trabajador, "de muy buen pluma", "de todas buenas partes que para su oficio se requieren $y$, particularmente, en lo que es fidelidad, confianza, diligencia y recato", son algunas de las calificaciones que apunta en relación a los diferentes oficiales. Sólo algunos de los integrantes del Tribunal merecen su abierto reproche: Por una parte, el inquisidor

inquisidores de Llerena y que tuvo por objeto al receptor del mismo Tribunal. Respectivamente, en AHN, Inquisición, leg. 1989, exp. 7 y exp. 5.

36 El visitador Dr. D. Luis de Copones recibió su comisión el 12 de febrero de 1585, AHN, Inquisición, leg. 1989, exp. 2, s/f. Para secretario de la visita se eligió en esta ocasión a Antonio de Zarauz, quien le acompañó desde Sevilla, quien, poco después fue sustituido. Así, en septiembre del mismo año, se comunicaba al visitador que "para notario de la visita que tenéis començada, hauemos embiado a Joan de Vergara, con quien se podrá proseguir y acabar con la breuedad que significáis", AHN, Inquisición, lib. 361, f. 394r.

37 En 1587 continuaba desempeñándose como inquisidor en Sevilla, ibídem.

38 AHN, Inquisición, leg. 1989, exp. 2, s/f. Junto a la comisión otorgada al visitador se encuentra también el formulario para el interrogatorio general seguido en estas visitas de inspección.

${ }^{39}$ Ibídem, exp. 2 y 11.

40 Ibídem, exp. 11, doc. 1. 
más moderno, quien -a juicio del visitador- ha querido "gobernar él todo", mostrándose, sin embargo, poco trabajador, falto de práctica en el estilo del Santo Oficio y tendente a "discordar con sus colegas" y a hacer de menos a los oficiales, granjeándose así la animadversión de todos ${ }^{41}$. De otro lado, uno de los notarios del Secreto, cuya habilidad en su oficio destaca, pero al que se había imputado algún hecho escandaloso y algunos "descuidos suyos muy notables y gruesos" que "son de culpar en un oficial" 42.

La visita puso de manifiesto asimismo algunos problemas en las dependencias destinadas a cárcel de familiares y en las que albergaban la documentación correspondiente al Juzgado de bienes, que trataron de solventarse de inmediato. Se intervino también muy rápidamente al observar ciertos defectos en algunos de los "papeles del notario de secuestros". Otros extremos observados por el visitador, requerían, sin embargo, la intervención de la cúpula inquisitorial, a la que aquél trasladó no sólo su opinión acerca de las sanciones disciplinarias que podían imponerse a los culpados en la visita -reprensión, en la mayor parte de los casos; suspensión de empleo en el caso del inquisidor y el notario del Secreto ya mencionados ${ }^{43}$-, sino también sus recomendaciones para mejorar algunas prácticas que generaban conflictos con los autoridades concejiles del amplio distrito de la Inquisición de Llerena, entre los propios miembros del Tribunal, o que dificultaban el perfecto desarrollo de la actividad del Santo Oficio de Llerena ${ }^{44}$.

\section{III.2. Visitas de la Inquisición de Llerena en el siglo XVII}

A lo largo del siglo XVII se contabilizan hasta ocho inspecciones del Santo Oficio de Llerena. La primera tuvo lugar durante el breve Generalato de Juan Bautista de Acevedo ${ }^{45}$ . Su probable desarrollo fue apuntado por Fernández Nieva en atención a alguna noticia aislada en la que se mencionaba la existencia de una visita, quizá en curso, pero que no permitía concluir si se trataba de la preceptiva visita del distrito o, en efecto, de una visita de inspección ${ }^{46}$. Poco se conoce, en todo caso, en relación a esta visita. Como antes señalé, la única documentación relativa a la misma que he podido localizar es un traslado de la

41 El visitador redactó, en este caso, un extenso informe en el que daba cuenta, de la evaluación que le merecían las circunstancias personales, conducta, forma de conducirse en el desarrollo de sus funciones de cada uno de los miembros del Tribunal y la forma en que se relacionaban entre sí, ibídem.

42 Un resumen de los cargos formalizados a los inquisidores, señaladamente al más moderno, Bernardo de Olmedilla, en FERNÁNDEZ NIEVA, J., “Inquisición interactiva...”, pp. 181-184.

43 En relación a este último, el visitador Copones propone que se le suspenda por un año, porque su actuación ha causado escándalo, pero que, al poco, sea recuperado para el oficio pues es buen trabajador y ha servido a la Inquisición durante muchos años, AHN, Inquisición, leg. 1989, exp. 11, doc. 1.

44 “Relaçión de las cosas generales que han resultado de la Visita de la Inquisiçión de Llerena hecha por el doctor Luis de Copones, inquisidor de Sevilla, para el Illmo y R ${ }^{\mathrm{mo}}$ señor Carl de Toledo, inquisidor general”, en AHN, Inquisición, leg. 1989, exp. 11, núm. 2; "Pareçer del Sr Inquor doctor Luis de copones sobre la visita que a hecho de los inquisidores y oficiales de la Inquisiçión de Llerena”, en ibídem núm. 1.

45 El obispo de Valladolid fue nombrado inquisidor general en 1603 y falleció en julio de 1608. En su breve mandato se interesó por la mejora de las retribuciones que percibían los miembros de los Tribunales de distrito con la vista puesta en adecuarlos a "la variedad de los tiempos [...] y a que con eso cesan otros inconvenientes que se podrían temer". GALVAN, E., El General, cit., pp. 234-240.

46 La referencia a la visita en una carta en que se da cuenta de la conducta inapropiada de uno de los notarios del Secreto, en AHN, Inquisición, leg. 1989, exp. 14. Sobre el particular, FERNÁNDEZ NIEVA, J., "Inquisición interactiva...", cit., pp. 168 y 184. 
Provisión de resolución de la visita, fechada en Valladolid, el 25 de octubre de 1605, algunos documentos que se acumularon a los de la visita y que permiten aproximarse al tiempo en que habría concluido la investigación ${ }^{47}$ y otros que se refieren al abono de sus retribuciones al equipo encargado en esta ocasión de visitar el Santo Oficio de Llerena ${ }^{48}$.

El motivo de la visita bien pudo ser el que ya parecía un problema instalado de forma irremediable en el Tribunal de Llerena. Esto es, la desafortunada relación entre sus miembros, que repercutía negativamente en el funcionamiento del Tribunal. En esta ocasión, el problema podría haber sido el trato poco respetuoso que los oficiales dispensaban a los inquisidores y el fiscal y que incomodaban a éstos. Así se pone de manifiesto por parte de uno de los inquisidores, en junio de 1605, haciendo referencia a la existencia de quejas en ese sentido remitidas anteriormente al inquisidor general. Con esa ocasión, se apunta la existencia de una visita girada sobre el Tribunal de Llerena, que, señala, no ha mejorado una situación que menoscaba la autoridad de los inquisidores ${ }^{49}$. En ese momento, probablemente la visita estaba ya concluida -aun cuando del tenor de lo manifestado por el inquisidor de Llerena no se deduzca con claridad-, toda vez que en la capa de la carta aparece anotado que debe "juntarse con lo que le toca a Vergara de la visita". La anotación está fechada el 28 de junio de 1605. Cuatro meses más tarde, la cúpula del Santo Oficio resolvía en relación a la visita que habría comenzado un año atrás, en 160450.

A partir de la extensa provisión despachada para resolver esta visita podemos conocer quiénes fueron designados como visitador y secretario de la misma, quiénes fueron los inspeccionados, qué cargos se formularon a algunos de ellos y qué decidieron el inquisidor general y el Consejo al respecto. El visitador fue, de nuevo, un inquisidor del Santo Oficio de Sevilla, que, como venía siendo habitual, propuso como secretario de la visita a uno de los notarios del Secreto de esa misma Inquisición. Conformaban la planta del Santo Oficio de Llerena en ese tiempo tres inquisidores, el fiscal, seis notarios del Secreto, el alguacil, el juez de bienes, el notario de secuestros, el receptor, el alcaide, el portero, etc. Tras la investigación, la mayor parte de ellos recibieron cargos de diferente entidad que comportaron, en el mejor de los casos, la reprensión. En otros, reprensión y la restitución de lo que se había percibido indebidamente. Aún en otros, la grave reprensión y la privación por tiempo determinado o a perpetuidad de llevar a cabo determinadas tareas especialmente apetecibles para algunos oficiales. A estas se sumaría, en los casos más

${ }^{47}$ Se trata de una carta remitida por un inquisidor de Llerena al inquisidor general y de los testimonios de las declaraciones efectuadas por él mismo y otros de los miembros del Tribunal en lo que parece ser una investigación de las irregularidades denunciadas al inquisidor general. Pueden verse en AHN, Inquisición, leg. 1989, exp. 14.

48 AHN, Inquisición, lib. 367, ff. 10vo-11r; 57vo-58r; 63vo-64r; 87r-vo․

49 "Antes que V.S. mandara haçer la Visita en esta Inquisición -apunta el inquisidor Simón Gaztelu- estavan los animos de muchos de ella tan ynquietos y desasosegados como V.S. habrá bien visto y después acá, no allo ninguna mejoría, ni parece ser esta Inquisición ni Santo Oficio sino vn campo de enemigo,s porque como con tales es necesario andar muy prevenidos de paciencia y de armas que nos defiendan y es de tal suerte que, en no haciendo lo que el oficial quiere, somos los más malos del mundo y se descomponen de manera que nos obligan a muy grandes pesadumbres", AHN, Inquisición, leg. 1989, exp. 14.

50 En septiembre de 1604 se abonaba al visitador y al secretario la ayuda de costa, por importe de 500 ducados, que se les habían señalado, por una sola vez, a cargo del receptor de la Inquisición de Llerena, por razón de la visita, AHN, Inquisición, lib. 367, 87r-vo. 
graves, la suspensión del oficio. Algunos de ellos se vieron además incursos en causas criminales, proseguidas en la Inquisición, que el Consejo ordenó se le remitiesen antes de su ejecución. Los cargos de los que fueron encontrados culpables tenían que ver con la ya mencionada falta de decoro con que algunos oficiales trataban a los inquisidores, con el "campo de enemigos" de que hablaba uno de los inquisidores al referir la situación del Tribunal. Pero también con otros graves excesos en los que habían participado, en diferente medida, inquisidores y oficiales. Me refiero ahora a las disfunciones detectadas por el visitador en lo tocante a las informaciones de limpieza de los servidores del distrito, o en las cuentas de los secuestros de bienes efectuados, o en las retribuciones percibidas por el abogado de presos ${ }^{51}$.

La segunda de las visitas se pondría en marcha tres lustros más tarde. El visitador procedía en este caso de la Inquisición de Zaragoza, Tribunal del que formaba parte también, en calidad de notario, el elegido para "asentar en la visita que hiciéredes -se recuerda al visitador-, por el notario ante quien pasare, todo lo que viéredes y entendiéredes ser necesario"52. La decisión fue tomada por el inquisidor general Aliaga a los veinte días de haber accedido al generalato ${ }^{53}$ y las razones apuntadas responden a las habituales en una visita general en la que se trata de tomar el pulso al Tribunal y sus servidores: "Sauer el estado de ella y si los negocios del Santo Oficio se hacen y exercitan con la rectitud y diligençia que conbiene al servicio de Nuestro Señor y buena administración de la Justicia y proueher lo que fuere necesario para descargo de nuestra conciencia", rezará la comisión otorgada al visitador, en Madrid, el 20 de febrero de 161954. Para Fernández Nieva, serían, una vez más, las desavenencias entre inquisidores y entre éstos y los oficiales lo que motivó la nueva visita. Refiere así los "encuentros grandes y pesadumbres" que pesaban sobre los dos inquisidores y a cómo éstos derivaban en el entorpecimiento de su trabajo. Apunta además que la mala relación entre ellos habría trascendido los muros del Tribunal, causando mucho escándalo en la villa de Llerena y siendo también conocida en otras partes del distrito. Habla así de caos y decadencia, de calamidad y desventura, al describir el estado del Tribunal con el que iba a encontrarse el visitador ${ }^{55}$. No cabe duda de que esto fue el detonante de la decisión de enviar un visitador a Llerena. De hecho, junto a su comisión, recibió amplía documentación relacionada con los "antecedentes de la visita", es decir, con las medidas que se habían adoptado con carácter previo para tratar de solventar el problema y que pasaron por la información a cargo de otro inquisidor y que habría dado ocasión de señalar ciertas sanciones a algunos de los investigados ${ }^{56}$.

\footnotetext{
51 Ibídem, ff. 19r-72vo.

52 El elegido por el inquisidor general es el Licenciado Miguel Santos de San Pedro, inquisidor apostólico del Reino de Aragón, el 20 de febrero de 1619. Para ejercer las funciones de secretario de la visita, fue designado Pedro Pérez de San Vicente, uno de los notarios del Secreto del Santo Oficio de Zaragoza, AHN, Inquisición, lib. 592.

53 GALVÁN, E., El Inquisidor General, cit., p. 270.

54 AHN, Inquisición, lib. 361, ff. 350r-351r.

55 “Inquisición interactiva...”, cit., pp. 184-185.

56 AHN, Inquisición, leg. 1990, exp. 1.
} 
La visita, como no podía ser de otro modo, fue en todo caso más allá. Se investigaron en efecto las razones y consecuencias del mal ambiente reinante en el Tribunal, pero no se descuidaron el resto de extremos a considerar a la hora de inspeccionar con carácter general una Inquisición. Fueron así examinados sus miembros y cuantos testigos se estimó preciso. Se revisaron las causas de fe despachadas por el Tribunal desde 1607 en adelante. Se examinaron, asimismo, los procesos criminales contra comisarios y familiares que estuviesen pendientes, formándose la oportuna relación de los mismos que se envió al Consejo. Se analizó el grado de cumplimiento del deber de realizar la preceptiva visita del distrito, formando una lista con las realizadas desde el año 1589 en adelante. Asimismo, se visitaron las cárceles y se interrogó a los presos. Con toda la información obtenida durante la instrucción, el visitador se formó una idea cierta de las presuntas irregularidades en que habían incurrido algunos miembros del Tribunal. Formados los cargos contra los mismos y recibidas y prácticas sus defensas, concluyó su informe para el Consejo. El resultado fue un voluminoso expediente de la visita, en el que quedaron documentadas todas las actuaciones del visitador y los resultados que se desprendían de las mismas ${ }^{57}$. Formando parte de la documentación remitida al Consejo, el visitador, en cumplimiento de lo que se había advertido en su nombramiento, remitió también su propio parecer sobre los diferentes miembros del Tribunal, de la que se desprende la "condición áspera" de un inquisidor, el carácter libertino y escandaloso de otros dos y la falta de cumplimiento de sus obligaciones por parte de todos ellos ${ }^{58}$. Los cargos fueron, en esta ocasión, acordes a la mala impresión general obtenida por el visitador: más de un centenar se formularon a dos de los inquisidores, en tanto el tercero recibía sesenta y cinco. Al resto de los miembros del Tribunal -juez de bienes, notarios del secreto, receptor, notario de secuestros, alcaide y su ayudante de las cárceles secretas- se les imputaron asimismo un total de ciento treinta y seis cargos por los que fueron efectivamente sancionados, en diferente grado, por sus superiores ${ }^{59}$.

Las irregularidades e incumplimientos eran en esta ocasión muy numerosas y afectaban tanto a la conducta personal de inquisidores y otros oficiales, como a su actividad profesional. Así, al grave cargo de incumplimiento de las Instrucciones y de las órdenes recibidas del Consejo, debían añadirse las ausencias o el hecho de dedicar el tiempo de asistencia al Tribunal a otros menesteres, lo que provocaba retrasos y perjudicaba a terceros, así como la grave falta de cumplimiento de la obligación de guardar secreto, o el hecho de haber procedido a la provisión indiscriminada de comisarios y familiares, por mencionar tan sólo algunos de los muchos formados a los inquisidores. En la faceta tocante a su moral personal, el amancebamiento y otras conductas indignas de su condición de clérigo y del oficio que desempeñaba en la Inquisición, completaban el cuadro de

\footnotetext{
57 Ibídem.

58 Ibídem, "Parecer dado por el visitador sobre los distintos miembros del Tribunal y relación de las causas que motivaron la visita".

${ }^{59}$ AHN, Inquisición, lib. 592, ff. 200r-262r, "Provisión de resolución de la visita que hizo el Dr. Miguel Sanctos de San Pedro, inquisidor de Aragón, de los inquisidores y oficiales de la Inquisición de Llerena”, Madrid, 28 de noviembre de 1620 .
} 
irregularidades puesto de manifiesto por el visitador60. A juicio del visitador, los tres inquisidores y algún otro oficial debían ser apartados del oficio que desempeñaban, siendo suspendidos, jubilados o, cuando menos, trasladados a otros Tribunales. Solicitó asimismo sanciones de índole pecuniario para varios de ellos. En su resolución, dictada dos meses después de haberse concluido la vista del expediente ${ }^{61}$, el Consejo acordó privar de su empleo, en efecto, al menos a dos de los inquisidores y uno de los notarios del Secreto, acerca de los que nos constan diferentes circunstancias en los meses siguientes. Así, el notario del Secreto habría suplicado la resolución, formulando de nuevo descargos en su favor, confirmándose por el Consejo la sanción de privación de empleo que se le había impuesto ${ }^{62}$. Por su parte, en relación a uno de los inquisidores, asimismo separado de su empleo, será el Concejo de Llerena el encargado de hacer llegar al Consejo la solicitud de su retorno, extremo éste que será considerado también para otro de los inquisidores llerenenses, que había sido trasladado a otro Tribunal. Finalmente, al inquisidor que resultó más culpado y al que se privó igualmente de empleo lo encontramos asimismo desempeñando esa misma función en la Inquisición de Cuenca unos años más tarde ${ }^{63}$.

Concluida la visita de 1619 y por lo que se refiere a los años inmediatamente siguientes, la documentación conservada en el Archivo Histórico Nacional apunta a la existencia de diferentes inspecciones que se suceden en un corto espacio de tiempo. Me refiero ahora a las catalogadas como "Visita del inquisidor Isidoro de San Vicente al Tribunal de la Inquisición de Llerena", "Visita del inquisidor Gabriel de Briones Ayala..." y "Visita del inquisidor Agustín de Villavicencio...", fechadas, respectivamente en 1623, 1633 y 163964 . No creo, sin embargo, que la primera pueda incluirse entre las visitas de alcance general que me ocupan, tratándose, en cambio, de una de esas pesquisas, visitas particulares, o inspecciones más o menos complejas, encomendadas a un inquisidor del propio Tribunal, o enviado a él desde otro por el inquisidor general. Este sería, a mi juicio, el caso de la investigación de algunos oficiales acometida en 1622 y en la que habrían intervenido, sucesivamente, dos inquisidores: el primero, un inquisidor del Tribunal de Cartagena de Indias, aunque residente en Sevilla, a quien se habría encargado, en agosto de ese año, encaminarse a Llerena, "con secreto" y con la asistencia de un notario del Secreto hacer averiguación acerca de ciertas denunciadas sobre dos de los inquisidores y el fiscal del Santo Oficio extremeño ${ }^{65}$. El segundo en intervenir fue, en efecto, el inquisidor Isidoro de San Vicente, inquisidor de Zaragoza, a quien se envía a Llerena como inquisidor y se le encarga

60 Los numerosos cargos, la documentación reunida por el visitador para sustentarlos, así como los descargos realizados por los inculpados, en AHN, Inquisición, leg. 1990, exp. 1.

61 "El lunes pasado se acabó de ver la visita de la Inquisición de Llerena y nos parece que el visitador no es menester aquí para otra cosa", se advierte en el Conejo el 10 de septiembre de 1620, AHN, Inquisición, lib. 591, ff. 11r-12o; Un mes antes se había advertido

62 Ibídem, ff. 57r-58r.

63 Ibídem, ff. $124 \mathrm{v}^{\mathrm{o}}-125 \mathrm{r}$.

64 http://pares.mcu.es/ParesBusquedas/servlets/Control_servlet [consultado: 20/08/2019].

65 La comisión extendida a Agustín Ugarte Saravia precisaba que se había recibido un memorial del Ayuntamiento de Llerena y varias cartas, una de ellas remitida por el Juez de bienes de aquél Santo Oficio, en la que apuntaba "los malos procedimientos de los dichos dos inquisidores Adam y Santos y del fiscal", AHN, Inquisición, lib. 594, f. 299r-300r. 
que, tan pronto como tome posesión de su nuevo destino, se apresure a ver los resultados de las averiguaciones realizadas poco tiempo antes, también por comisión del inquisidor general ${ }^{66}$. La pobre documentación que se ha conservado sobre esta investigación consiste en dos reducidos expedientes en los que constan los testimonios prestados ante el secretario Argüello por diferentes personas que, habiendo sido señaladas como testigos en su descargo por los respectivos inculpados -el fiscal y el alguacil del Santo Oficio de Llerena, no fueron, en su día, examinados por el responsable de la investigación, probablemente por residir fuera de la villa extremeña. De estos se desprende, tan sólo, información relativa a los cargos que se habían formulado por el inquisidor de Llerena a ambos oficiales y que éste debió enviarlos al Consejo. No consta, sin embargo, qué resolvió hacer la Suprema con los testimonios tomados por su secretario, ni, en todo caso, la resolución adoptada en relación a los cargos formulados. Tampoco es posible saber, claro está, si otros oficiales resultaron asimismo culpados como resultado de la investigación llevada a cabo por el inquisidor San Vicente. Parece probable que así fuera, si atendemos a las comisiones remitidas a los dos inquisidores que intervinieron en la misma, a tenor de las cuales debían averiguar qué había de cierto en la incorrecta actuación de los dos inquisidores, del fiscal y de uno de los notarios del Secreto. Un negocio -a decir del Consejo- "de tanta importancia" y en el que se advierte es preciso tener cuidado en evitar que en la documentación se reseñen nombres de personas señaladas de la localidad, precaución que en el Consejo se ha tomado al remitir la información a los comisionados para la investigación ${ }^{67}$. Secreto se recomendó al primer comisionado, que no debió tener suerte en la elección del notario que debía asistirle, lo que quizá retrasó su trabajo. San Vicente habría heredado así un expediente inconcluso, que debió despachar, eso sí, en poco tiempo, haciéndose cargo simultáneamente de la dirección del Tribunal de Llerena.

El siguiente registro, en orden cronológico, corresponde a una visita iniciada en 1633, que habría corrido a cargo del inquisidor Gabriel de Briones Ayala68. Siendo relevantes las lagunas existentes en la documentación que se ha conservado, es posible apreciar que la investigación alcanzó a un buen número de oficiales, aun cuando, probablemente, no se trató tampoco de una visita general ${ }^{69}$. Con todo, se trata de un interesante expediente en el que se aprecia de nuevo el trasfondo de malas relaciones entre los miembros del Tribunal. El resultado de la investigación implicó la formación de numerosos cargos a tres notarios, al fiscal y a los inquisidores llerenenses. Ciertamente, no todos de la misma gravedad, ni tampoco tan numerosos ${ }^{70}$. El que resultó más culpado fue el inquisidor Cristóbal Serrano Osorio, al que se acumularon cerca de un centenar de cargos y

${ }^{66}$ Ibídem, lib. 592, f. 317.

67 Ibídem, ff. 310v-311r.

68 AHN, Inquisición, leg. 1989, exp. 10.

${ }^{69}$ Así pareció entenderlo el visitador llegado a Llerena en 1643, que requirió información acerca de todos los servidores del Santo Oficio de Llerena -estuviesen o no en el mismo en ese momento- "desde la Visita general que hizo en ella el Doctor Don Miguel Santos de San Pedro, Inquisidor de Aragón, el año de 1620". En otro momento se refiere a ésta como "la última visita general", AHN, Inquisición, leg. 1993, exp. 1.

70 Los cargos formados por Briones a los miembros del Tribunal culpados en la visita, en AHN, Inquisición, leg. 1989, exp. 10, ff. 1r-64r. 
que fue sancionado con privación de su empleo por cuatro años ${ }^{71}$ y al que se permitió, no obstante no caber suplicación de este tipo de sentencias, alegar ante el Consejo lo que estimase conveniente para tratar de obtener una revocación o minoración de su condena ${ }^{72}$. En apoyo de su defensa, el Concejo de Llerena no dudó en expresar su sentimiento por el trato dispensado a un inquisidor del que decían "tener largas experiençias de las muchas partes de entereça y rectitud y justificaçion que concurren" en él "y de sus loables y virtuosas costumbres y buenos procedimientos en administrar Justiçia quieta y pacíficamente, procurando en todas ocasiones evitar competencias, con mucha cordura y prudençia"73. No faltaron tampoco muestras de la opinión que merecía a sus colegas la actitud personal y el desempeño profesional del inquisidor Serrano Osorio, que se hicieron llegar al Consejo y que éste dispuso, que se uniesen con los de la visita, antes de proceder a resolver sobre la misma $^{74}$. La defensa del inquisidor se basó justamente en la indefensión que se le había procurado al no admitir la tacha de numerosos testigos claramente resueltos a deponer contra él por enemistad 75 . No consta en el expediente si la apelación a que, entendiendo su situación, se le concediese la gracia de reintegrarlo al Santo Oficio llegó o no a prosperar.

La que no ofrece dudas acerca de su condición de visita general del Tribunal de Llerena es la ordenada por el inquisidor general Antonio de Sotomayor y el Consejo de Inquisición, en septiembre de 1639. Se conserva, en este caso, un rico expediente cercano a las cuatro mil páginas, en el que resultan de especial interés sendos informes emitidos por el visitador. Dirigidos al Consejo de Inquisición, en uno de ellos describe con gran precisión cada uno de los pasos seguidos en la visita. El segundo, contiene su parecer sobre aquellos extremos que debían ser objeto de atención por parte de la cúpula inquisitorial ${ }^{76}$. Este segundo documento, de valor muy apreciable, es el preceptivo memorial que debía remitirse al Consejo al finalizar una visita y del que me he servido ya en relación a inspecciones anteriores. Más o menos rico, dependiendo claro está del modo de hacer del visitador de turno, contiene una suerte de compendio de los cargos formulados, a los que se añade la propia opinión del visitador acerca de su posible sanción y, en algunos casos, advertencias o recomendaciones acerca de las medidas a adoptar para corregir las malas prácticas detectadas en el curso de la visita. El primero de los informes que he mencionado no es, sin embargo, habitual. En buena medida viene a ser una suerte de autoinforme dirigido al Consejo con el que pretende trasladar el satisfactorio trabajo que ha realizado en la visita. De hecho, el memorial incluye también la referencia somera a su trayectoria anterior. El objeto del mismo sería así granjearse el reconocimiento del Consejo y obtener,

71 "En la villa de Madrid aviendo se visto los dos cargos por el Ilmo Sr. Ob. de damasco, inq. gl y ss del consejo y votado el fin de los dichos cargos, condenaron al dho inq don Xpoval serrano Osorio por la culpa que de ellos resulta en quatro años de suspensión del exercicio de inquisidor, los quales se quenten desde el día de la notificación de esta sentencia", 27 agosto 1634, ibídem, f. 67r.

72 El decreto, fechado el 26 de octubre de 1634, se le notificó dos días más tardes, ibídem, f. 81 r.

73 Ibídem, ff. 79r-vo.

74 Ibídem, ff. 67r-78r.

75 Ibídem, ff. 62r-83r.

${ }^{76}$ Ambos informes en AHN, Inquisición, leg. 1993, exp. 1. 
en lo posible, alguna compensación a sus muchos desvelos ${ }^{77}$. Con independencia de la motivación de su autor, lo cierto es que el informe sobre lo actuado en la visita ofrece al lector una primera aproximación muy detallada al conjunto de las actuaciones, del que me sirvo para la breve referencia a esta inspección que me propongo.

El elegido, en 1639, para actuar como inspector fue el inquisidor Agustín de Villavicencio, procedente, una vez más, del Santo Oficio de Sevilla. Se hizo acompañar en la visita por uno de los notarios del Secreto de esta misma Inquisición ${ }^{78}$. Llegados ambos a Llerena, el primer auto que proveyó el visitador -tras haber comunicado su comisión a inquisidores y resto de ministros y obtenido de ellos el acatamiento debido- fue requerir que se le facilitase una nómina de todos los ministros y oficiales que serían examinados, esto es, todos aquellos que habían ejercido sus empleos en ese Santo Oficio desde la conclusión de la última visita general en 1620. A partir de ahí, comenzaron las citaciones, interrogatorios y las listas de contestes. Un total de ciento cuarenta y nueve testigos fueron examinados. Se dirigieron las comisiones precisas a comisarios del distrito y a otras inquisiciones, para obtener la declaración de los que no estaban presentes en la villa de Llerena. Otro dato significativo a tener en consideración en esta visita, es la inclusión, en el interrogatorio general del que se daba traslado a los visitadores junto a su comisión, de nuevas preguntas que tenían por finalidad sacar a la luz aspectos concretos que habían sido revelados por las denuncias recibidas en Madrid o por los testimonios obtenidos en el curso de la visita 79 . Algunas de las cuarenta y nueve cuestiones habituales fueron así alteradas para acomodarlas a las circunstancias que debían investigarse. A finales de marzo de 1640 se había concluido la fase de instrucción en lo que tenía que ver con los interrogatorios al staff del Tribunal y a los testigos. Comenzó entonces la visita de la Cámara del Secreto, en la que apreció algunos defectos relevantes en el concierto y confusión de los papeles. Una situación igualmente preocupante -describe nuestro inspector- fue la que halló en el Juzgado de bienes, en el que, a su juicio, resultaba muy complicado conocer los censos y las rentas que devengaban y se detectaban graves incumplimientos en la obligación de remitir puntualmente al Consejo las cuentas de los depósitos de pretendientes y otros tantos documentos. Formalizó finalmente centenar y medio e cargos, de los que se dio traslado a los interesados y el preceptivo plazo para argumentar en su defensa. Abierta ya así la fase contradictoria del procedimiento, se procedió al examen de ciento sesenta y siete testigos propuestos por los inculpados en apoyo de sus defensas. Al propio tiempo se examinaron

77 Refiere, por ejemplo, "el desinterés y aliento con que, en el discurso de tantos años de Inquisidor, he gastado de mi renta eclesiástica y temporal más de treinta mil ducados en servicio de V.A., no hauiéndome valido quatro mil los gajes que gozo desde el de 1636", ibídem.

78 Agustín de Villavicencio -a decir de él mismo- había prestado servicios por espacio de veinte y dos años en la Inquisición de Sevilla, en la que había comenzado a servir como comisario de Cádiz, en donde era a su vez deán de la Catedral. La comisión para la visita general de la Inquisición de Llerena se le entregó el 16 de septiembre de 1639. Dos meses más tarde, habiendo cerrado los asuntos que tenía pendientes, se puso en camino hacia Llerena, instalándose provisionalmente en el Convento de San Francisco de esa villa, de donde pasó después a las conocidas como casas viejas de la Inquisición. Por su parte, el designado, el 7 de octubre de 1639, como secretario de la visita, Bernardo de Azme, desempeñaba la tarea de notario del Secreto en el Santo Oficio de Sevilla.

${ }^{79}$ AHN, Inquisición, lib. 1993, exp. 1, ff. XVIr-XXIvo. "Por las preguntas siguientes se examinarán los testigos que testificaren en la Visita de los Inquisidores y oficiales de la Inquisición de Llerena”. Los capítulos que resultaron alterados fueron el 1, 6-8, 17, 24, 36, 50-52 y 54 . 
causas y otros papeles en los que aquellos decían fundamentar sus descargos. A partir de ahí -pero de esto no nos habla Villavicencio en su informe- se elevarían los cargos a definitivos y se daría traslado de los mismos al Consejo para la resolución de la visita ${ }^{80}$. Al respecto, había recibido la indicación expresa de que acudiese él mismo a la Corte, llevando consigo los autos ${ }^{81}$.

Si la investigación de Villavicencio concluía en 1640, apenas tres años más tarde se otorgaba comisión al Doctor Bartolomé Paravicino San Vicente, fiscal del Tribunal de Toledo con residencia en la Corte, para investigar algunas denuncias llegadas al Consejo. La inspección que debía realizarse tenía un alcance limitado ${ }^{82}$. Hasta el Consejo habían llegado denuncias relativas a ciertas irregularidades cometidas por los inquisidores, el fiscal y uno de los notarios llerenenses ${ }^{83}$. La comisión otorgada a Paravicino, en la que se señalaba como secretario a uno de los de la Inquisición de Barcelona, refería escuetamente que se trataba de "los excesos y otras cosas que se hicieron" en las pruebas para familiar del Santo Oficio de un vecino de la propia villa ${ }^{84}$. En cumplimiento de la misma, examinó a cerca de noventa testigos y formó los cargos que se desprendían de la investigación a algunos miembros del Tribunal. Al propio tiempo, Paravicino, al que se había urgido desde el Consejo para que concluyese a la mayor brevedad sus averiguaciones, daba cuenta al Consejo de la existencia de irregularidades en el Tribunal que bien merecerían atención y a los que no podía prestarla "por quedar fuera de la comisión que se le había extendido"85.

La investigación realizada por el fiscal de la Inquisición de Corte por espacio de ochenta y cinco días -que se amplió, después, a algunos de los extremos que había apuntado-, constituiría el punto de partida de la una nueva visita a cargo del inquisidor del Tribunal de Barcelona, Francisco Antonio Díaz de Cabrera, penúltima de las giradas sobre el Santo Oficio de Llerena en el siglo XVII86. La intervención del inquisidor barcelonés está profusamente documentada, habiéndose conservado testimonio de numerosas actuaciones que, juntamente con las ya realizadas por Paravicino, concluyeron con la presentación de cargos contra los inquisidores llerenenses, el fiscal, el alguacil mayor, tres de los notarios

\footnotetext{
${ }^{80}$ Los cargos y resoluciones sobre los mismos en AHN, Inquisición, legs. 1990, 1991 y 1993.

81 El Consejo de Inquisición al visitador de Llerena, 27 de marzo de 1640, AHN, Inquisición, leg. 1993, exp. 1.

82 En este sentido, el propio Paravicino indicará en diferentes momentos que no puede seguir esa línea de investigación "por no llevar orden", AHN, Inquisición, leg. 1991, exp. 1.

${ }^{83}$ Las denuncias recibidas en el Consejo, algunas de ellas formuladas por miembros del propio Tribunal de Llerena, en AHN, Inquisición, leg. 1993, exp. 4.

${ }^{84}$ La comisión está fechada el 18 de noviembre de 1643 y puede verse en AHN, Inquisición, lib. 592 y en AHN, Inquisición, leg. 1991, exp.1.

85 En una comunicación al Consejo, fechada el 4 de diciembre de 1643, refiere que ha advertido y tenido que omitir "muchas cosas, de que no llevaba comisión, muy dignas de remediar, de que haré relaçión siendo necesario", ibídem.

86 FERNÁNDEZ NIEVA se refiere confusamente a una visita realizada en los años cuarenta del siglo XVII en la que habrían intervenido sucesivamente el inquisidor sevillano Villavicencio y Paravicino, al que sitúa asimismo en el Tribunal de Sevilla. Sobre los resultados de la investigación realizada por ambos, tan sólo indica que la mayor culpa -"la oveja descarriada"- recayó sobre el entonces ya inquisidor de Llerena, Pedro Llerena Bracamonte. No menciona tampoco la inspección llevada a cabo por Francisco Antonio Díaz de Cabrera, señalando que existe un vacío documental hasta finales de siglo, “Inquisición interactiva...”, cit., pp. 187-189.
} 
del Secreto, el receptor y el contador del Santo Oficio ${ }^{87}$. Concluida la compleja investigación, que Díaz de Cabrera dice iniciada en junio de 164488, el Consejo habría resuelto imponer graves sanciones a algunos de los miembros del Tribunal que resultaron apartados de su empleo por tiempo determinado, señalándose, en algún caso, que, transcurrido ese tiempo, no pudiesen regresar al Tribunal de Llerena ${ }^{89}$.

Las disfunciones detectadas tenían que ver en esta ocasión no sólo con las difíciles relaciones entre los miembros del Tribunal, que en este caso parecieron centrarse en cierto conflicto con ocasión de la elección de oficios de la Cofradía de San Pedro Mártir, sino también con graves irregularidades en las informaciones de limpieza como era la alteración intencionada de los Libros de genealogías, el incorrecto desarrollo de alguna causa de fe que habría dado lugar a que se resolviese la revisión del proceso, o las conductas manifiestamente escandalosas de algunos de los integrantes del Tribunal ${ }^{90}$.

La última de las visitas corrió a cargo de nuevo de un inquisidor procedente del cercano Tribunal del Santo Oficio de Sevilla, al que acompañó un notario del Secreto del mismo Tribunal ${ }^{91}$. La visita, de la que desconozco el punto de partida, esto es, la decisión de designar visitador y secretario, debió comenzar en 1696, dictándose las correspondientes sentencias en el verano del año siguiente. De la documentación conservada se desprende sin lugar a dudas el carácter de visita general de esta inspección. La comisión extendida en su momento al visitador debía incluir la fórmula habitual en estos casos, haciendo referencia a que se le cometía la "visita de la Inquisición de Llerena y de sus ministros". A partir del poder que se le otorgaba, la investigación se centraría en la averiguación del correcto o incorrecto funcionamiento del Tribunal, resultando algunas disfunciones y los consabidos cargos contra algunos de sus miembros. En esta ocasión, llama la atención el desigual volumen de documentación relativa a la inspección realizada a uno de los inquisidores, si se compara con el resto de la conservada. En efecto, conformaban la planta del Tribunal en ese momento -según certificación expedida por el secretario Diego de Ribera ${ }^{92}$ - tres inquisidores, el fiscal, seis notarios del Secreto y un notario de secuestros, un contador, un notario del Juzgado, el alcaide, el nuncio, el portero, un abogado y un procurador del fisco, un cirujano, un médico, dos capellanes, un ayudante del alcaide y un proveedor para los presos. Recibieron cargos derivados de su incorrecta actuación, o por

${ }^{87}$ Se han conservado, junto con los antecedentes de la visita, la extensa documentación correspondiente a los cargos, su notificación a los inculpados, tachas de testigos, pruebas propuestas, etc. Asimismo, testimonios sacados por el secretario de la visita de diferentes documentos obrantes en el Secreto, sobre determinados procesos, o relativos al secuestro de bienes, AHN, Inquisición, legs. 1990, 1991 y 1993.

88 No he localizado la comisión otorgada al visitador, ni el nombramiento del secretario de la visita, que resultó ser un notario del Secreto de la Inquisición de Barcelona, Damián de Fonolleda. Sobre el comienzo de las actuaciones, el propio Díaz de Cabrera, en AHN, Inquisición, leg. 1990, exp. 6, núm. 2.

${ }^{89}$ Así sentenció el Consejo, el 21 de octubre de 1647, en relación al notario del Secreto, Lorenzo Gutiérrez de Valverde, a quien se condenó a dos años de suspensión y a no poder ejercer de nuevo en el Tribunal llerenense, AHN, Inquisición, leg. 1991, exp. 39.

90 Los cargos en AHN, Inquisición, legs. 1990-1993; la resolución recaída en cada caso en AHN, Inquisición, leg. 1990, exp. 3; leg. 1991, exps.6, 15, 16, 29, 34 y 39; leg. 1993, exp. 2.

91 El Licenciado Fabián Díaz de Cabrera y Mateo de Ondategui, respectivamente. AHN, Inquisición, leg. 1994, exp. 1, f. 3r.

92 AHN, Inquisición, leg. 1994, exp. 1, ff. 200r-208r. 
causar escándalo por llevar una vida desordenada, cuatro de los notarios, el portero y los nuncios, el ayudante del alcaide -a quien, debido a su extrema pobreza, no se sancionó con las penas pecuniarias que le habrían correspondido-, uno de los numerosos comisarios del extenso distrito y también los inquisidores. Y es, en particular, a uno de éstos, el inquisidor Pedro de Eslava y Zayas, a quien se formuló el mayor número de imputaciones -hasta cincuenta y cinco, muy dispares, eso sí- y las más graves sanciones. De él dice Fernández Nieva que era cura y provisor y que le conocían como "Pedro mentiras"93. "Mentiroso, tramposo y mala cabeza" -recuerda Alonso ${ }^{94}$ - eran algunos de los calificativos de la opinión pública sobre este ministro.

Pedro de Eslava y Zayas había ejercido previamente como fiscal en la Inquisición de Llerena, de donde pasó a la de Murcia ya como inquisidor, en 1686. De regreso a Llerena, en el tiempo en que se inicia la visita general del Tribunal del Santo Oficio de esta ciudad, era el inquisidor más antiguo del Tribunal. En otoño de 1696, el inquisidor general Rocabertí le concedió licencia para ausentarse de su empleo por espacio de un mes ${ }^{95}$. Apenas medio años después sería desterrado de Llerena. Previamente se había dispuesto su reclusión en un convento, alejado asimismo de la ciudad y en el que recibiría la notificación de la resolución de la visita. Fue, sin duda, el más duramente sancionado de todos los servidores del Santo Oficio de Llerena que habían sido inspeccionados en la misma visita y también en las realizadas con anterioridad a ésta. Los cargos que se le imputaron resultaban ciertamente muy graves: quebrantamiento del Secreto, contravención de algunas Instrucciones y Cartas acordadas, nepotismo, retrasos e incumplimientos en perjuicio del fisco de la Inquisición, incumplimiento de obligaciones derivadas de su empleo como la visita de las cárceles, mala praxis en la tramitación de la causas de fe, prevalencia de su empleo para obtener beneficios personales y otros tantos que tenían que ver asimismo con diferentes faltas u omisiones de sus obligaciones. A estos se sumaban un carácter iracundo, una forma de hablar obscena y un relajo moral, que le permitía mantener, a la vista de todos, una relación con su ama.

No es de extrañar que el grueso del expediente de la visita se refiera a este inquisidor y sus múltiples responsabilidades. De este modo, a pesar de que también otros fueron culpados y severamente sancionados como resultado de la visita, es la resolución dictada en el caso de Pedro de Eslava la que llama la atención por lo inhabitual de su rigor: De una parte, se le condena a cuatro años de destierro de Llerena y seis leguas en su contorno, de los que los dos primeros deberá cumplirlos recluso en un convento en la provincia de San Pedro de Alcántara, "sin salir de él ni de su clausura y esparcimiento que en él tienen sus religiosos, sin expresa orden y licencia del inquisidor general". Por otro lado, se le impone la suspensión y privación de su empleo tanto en Llerena como en otros Tribunales de distrito,

\footnotetext{
93 No ofrece, sin embargo, ningún dato de interés acerca de la visita, más allá de la breve referencia a lo que podría haber sido, según este autor, la razón de ser de su inicio: una suerte de conjura urdida contra el abogado del fisco del Tribunal de la Inquisición de Llerena. FERNÁNDEZ NIEVA, J., “Inquisición interactiva...”, cit., p. 190.

94 Se refiere a este como una muestra de que "el tribunal de Llerena funcionaba muy deficientemente" y se detiene en el análisis de los cargos y la sentencia recaída al inquisidor Pedro de Eslava y Zayas. ALONSO, M.L., “Vías de revisión de la sentencia en el proceso inquisitorial”, en Cuadernos de Historia del Derecho, 2 (1995), pp. 151-187.

95 La información genealógica de Pedro de Eslava y Zayas, en AHN, Inquisición, leg. 1555, exp. 5; Sobre su trayectoria en el Santo Oficio, AHN, Inquisición, leg. 1994, exp. 1, ff. 2r-vo․
} 
dejando únicamente en manos del inquisidor general la posibilidad de absolverle. Por último, acumula un sinfín de amonestaciones, apercibimientos, graves apercibimientos y cuantiosas penas pecuniarias.

Finalmente, a otra circunstancia reseñable en este caso estriba en el hecho de que es el propio visitador, el inquisidor sevillano Fabián Díaz de Cabrera quien resuelve en relación a cada uno de los imputados, dictando "autos definitivos, en fuerza de sentencia" y disponiendo su notificación por el secretario de la visita ${ }^{96}$. Y Eslava, que se siente -como él mismo apunta- agraviado e injuriado, reclamará la posibilidad de apelar la sentencia, ofreciendo deducir sus defensas ante la nueva instancia ${ }^{97}$. El Consejo, por su parte, a la vista de lo resuelto por el visitador acordó, un mes más tarde, confirmar la sentencia, al tiempo que tomaba cuidadosa nota de aquellos aspectos en los que era necesario intervenir para evitar la mala praxis en adelante ${ }^{98}$.

\section{Recomendaciones, advertencias y medidas para la mejora de la práxis inquisitorial}

La naturaleza del poder conferido a los visitadores de los Tribunales inquisitoriales no ha interesado especialmente, conviniéndose en que la comisión que se les otorga les faculta para llevar a cabo la instrucción de un procedimiento en el que la resolución corresponde al inquisidor general y la Suprema ${ }^{99}$. Siendo esto así con carácter general, en ocasiones -como acabo de apuntar al tratar de la visita del Santo Oficio extremeño de finales del siglo XVII-, el visitador recibía "jurisdicción especial” del inquisidor general, de suerte que podía, en efecto, resolver en forma de sentencia definitiva:

En la Villa de Fuente de Cantos, a Veinte y tres días del mes de Junio de mil seiscientos y noventa y siete años, el señor Inquisidor Lizenciado Don Fabián de Cabrera, Inquisidor Apostólico del Reyno de Seuilla, electo Fiscal del Consejo Supremo de la Santa General Inquisición, Visitador de la Inquisición de la Villa de Llerena y sus Ministros por comisión del Excelentísimo Señor Arzobispo de Valencia, Inquisidor General, y Señores del dicho Consejo Supremo de la Santa General Inquisición, hauiendo pasadao a esta Villa y en vista de los cargos que en esta Visita se han hecho y sacado contra [...] y culpa que contra él de ellos resulta, y usando de la Jurisdicción, que para Sentenciarlos y determinarlos le está concedida por el Excelenstísimo Señor

96 Así, en el caso del inquisidor Pedro de Eslava y Zaras, AHN, Inquisición, leg. 1994, exp. 5; también en los de Sebastián de Valencia, ayudante del alcaide de las cárceles secretas, que fue amonestado y apercibido de privación de empleo si volvía a conducirse de igual manera, ibídem, exp. 9; o el del portero, Pedro de la Pila y los nuncios Esteban Guerrero, el mayor y Esteban Guerrero, el mozo, AHN, Inquisición, leg. 1994, exp. 11; o el del inquisidor Francisco Montero de Obregón, ibídem, leg. 1994, exp. 13; el comisario Juan de Carvajal, ibídem, exp. 14; el notario del Juzgado de bienes, Alonso Gordillo, ibídem, exp. 15; o los notarios Aguilar y Fernández Rangel, ibídem, exp. 16 y el notario Lorenzo Gutiérrez Valverde, a quien se apartó por dos años de su empleo, ibídem, exp. 39, núm. 2.

97 Ibídem, exp. 1, ff. 333 r y voo.

98 Ibídem, exp. 51, ff. 15r-19vo .

${ }^{99}$ En este sentido, por ejemplo, para J. CONTRERAS, el visitador carece de facultades resolutivas y se limita a realizar "un trabajo exclusivamente informativo", El Santo Oficio de la Inquisición en Galicia: 1560-1700. Poder, sociedad y cultura, Madrid, ed. Akal, 1982, p. 305. 
Arzobispo de Valencia, Inquisidor General y Señores del Consejo, por su carta de nuebe de Mayo próxime pasado y de nuevo por la de diez y ocho de dicho mes, visto todo, con lo nuebamente actuado y nueba culpa que contra él ha resultado después de sus defensas con las de nuevo hechas. Dixo que le debía condenar y condeno en la forma siguiente: [...] ${ }^{100}$.

Resultando, pues, excepcional que el visitador no concluyese la visita con su informe exhaustivo de los cargos y la propuesta de sanciones que, a su juicio, podrían imponerse, de lo que no cabe duda, en todo caso, es de que el poder otorgado al visitador le permitía, casi siempre, ir más allá de la mera instrucción y formación de la "sumaria". Si atendemos así a uno cualquiera de los títulos despachados a los numerosos inquisidores elegidos para desarrollar esa función en el siglo XVI, es claro que se requiere de ellos algo más:

y mandamos que las informaciones y deposiciones y otras qualesquier diligençias que por vos se hizieren y resçibieren en la dicha uisitaçion, nos las traygáis o enviéis con el nuncio del dicho offo o con otra persona de confiança y firmadas de vro nonbre y signadas del dho notario ante quien passaren y cerradas y selladas con vro paresçer, para que por nos visto se haga y prouea mediante justicia. Y es nra voluntad que, si entre tanto que nos vemos la dicha uisitaçion y proueemos en las cosas en ella contenidas lo que hazer se deua y vos paresçiere que se deue proueer y mandar hazer en la dha inquisiçion algunas cosas neçessarias a la buena administraçion de la Justicia y exerçiçio del Santo offó, lo podáis hazer y proueer, lo qual mandamos que se guarde y cumpla como si por nos fuere proveydo y mandado, para lo qual todo que dicho es y cada cosa y parte dello con todas sus inçidençias y dependencias, anexidades y connexidades, vos damos poder cumplido y cometemos mas vezes fasta a nos especial y expresamente las aduoquemos ${ }^{101}$.

El inquisidor designado para llevar adelante una visita general está facultado para adoptar, sobre la marcha, cuantas decisiones estime necesarias para favorecer un mejor funcionamiento del Tribunal ${ }^{102}$. Y en efecto, de estas actuaciones de los visitadores tenemos sobradas muestras en el caso de las inspecciones de que fue objeto el Santo Oficio extremeño ya en el siglo XVI. Así, puede mencionarse, en primer lugar, la intervención del visitador Martín Villar, como resultado de la inspección que llevó a cabo en las cárceles en 1565. La inspección ocular y los interrogatorios a los presos y al personal a su cuidado le permitieron hacerse una idea cabal de la situación en las cárceles, decidiéndole a adoptar algunas medidas para remediar aquellos extremos que consideró más urgentes. Por una parte, llamó la atención de los inquisidores sobre la necesidad de agilizar el despacho de las

100 Con todo, la intervención del Consejo se produjo a continuación -como se ha visto-, revisándose cada uno de los cargos y penas señaladas y anotándose cuidadosamente al margen de los mismos el parecer de la cúpula inquisitorial, AHN, Inquisición, leg. 1994, exp. 5, f. 16r.

101 "Poder de Inquisidor y visitador del Lizenciado Martín de Villar", expedido en Madrid, el 20 de abril de 1565, AHN, Inquisición, leg. 1989, exp. 1, ff. 3r-voo.

102 Sobre la excepcional autoridad ejecutiva de que se dotaba a los visitadores de los Tribunales ultramarinos y la falta de ella, en general, en los restantes casos, LEA, H.Ch., Historia de la Inquisición, cit., II, p. 89. 
causas, argumentando que "ha abido mucha dilaçion y están afligidos" los presos ${ }^{103}$. El principal problema observado, no obstante, tenía que ver, por una parte, con la "estrechez de la cárcel perpetua", que -a decir del visitador- no solo provocaban falta de comodidad, calor y apretura y enfermedades, sino que daba ocasión a disensiones y riñas entre ellos " $y$ otras cosas inhonestas que podían suceder". Por otro lado, el visitador había detectado graves incumplimientos en la gestión de los miembros del Tribunal responsables de la cárcel perpetua. Para remediar la primera de las cuestiones apuntadas y lograr cierto alivio en las cárceles secretas, el visitador, en concurso con inquisidores llerenenses, dispuso que se diese licencia para que algunos de los penitentes, que pudiesen permitírselo, alquilasen casas en las que cumpliesen su penitencia y que otros únicamente pernoctasen en la cárcel de penitencia, debiendo todos ellos acudir los domingos y días de fiesta de guardar para asistir en compañía del alcaide de la cárcel perpetua a la misa ${ }^{104}$, lo que pareció llamar la atención al visitador llegado a Llerena apenas quince años más tarde ${ }^{105}$. En cuanto a las irregularidades en lo tocante a la atención a los penitentes, la decisión del visitador fue tajante: requerir a los inquisidores para que removiesen al alcaide de la cárcel perpetua "luego sin esperar a la resolución de esta visita"106. No sería, sin embargo, ésta la única ocasión en la que la situación de algunas de las dependencias del Tribunal de Llerena preocupó seriamente a los visitadores. Con ocasión de la inspección realizada en 1585, el visitador constató asimismo que la cárcel de penitencia o perpetua ocupaba una casa alquilada, "buena y acomodada", con cargo al fisco del Tribunal. En peor estado halló las dependencias que servían como cárcel de familiares y las habitaciones destinadas al Juzgado de bienes y al notario de secuestros. Consideró entonces que debía procederse de inmediata a la habilitación de un espacio al que pudiese trasladarse los papeles custodiados por el notario de secuestros "donde se pudiesen poner con seguridad, así éstos, como los del Juzgado [de bienes] y, si pudiese ser, huuiese también lugar para carçel de familiares, que al presente no la ay, y es de muy grande inconveniente". Un auto del visitador dispuso que se tomase de inmediato una nueva casa que resolviese la situación en tanto el inquisidor general y el Consejo resolviesen otra $\operatorname{cosa}^{107}$. El propio visitador se ocupó de inspeccionar

103 AHN, Inquisición, leg. 1989, exp. 1, f. 252v.

104 Ibídem, f. $297 \mathrm{v}$.

105 El visitador Luis de Copones parece inicialmente escandalizado por la laxitud con que se cumple la penitencia, refiriendo al Consejo la situación: "A algunos de los reconciliados que están condenados a hábito y carçelería en la casa de la penitencia o cárcel perpetua, se an acostumbrado de mucho atrás los Inquisidores de esta Inquisición dar liçençia o permitirles que biuan con el hábito en casas propias de sus moradas, con que todos los domingos y fiestas acudan a la carçel perpetua y de allí, con los demás penitentes, vayan con el alcaide a la iglesia mayor y de esta manera hay oy en esta Villa tres reconçilidos, el uno mesonero y los dos çapateros". Conviene, seguidamente, en que quizá sea la mejor de las soluciones en esos tres casos, al tratarse de individuos con familias a su cargo, que carecerían de otro sustento. Esto le lleva a firmar: "Por stas razones no he querido alterar cosa ninguna, ni mandar a estos tres que biuen en sus moradas que se recogiesen a la carçel perpetua, por concurrir en ellos todas las qualidades referidas, sino dar cuenta de ello a Vuestra Señoría Ilustrísima para que mande lo que sea seruido y parece se podría ordenar a los Inquisidores no diesen, de aquí adelante semejantes liçençias sin orden de Vuestra Señoría Ilustrísima o del Consejo, o a lo menos que fuesen muy raras vezes y en casos de muy preçisa y urgente necesidad", AHN, Inquisición, leg. 1989, exp. 11, ff. 16r-vo.

106 Auto de 22 de julio de 1565, en AHN, Inquisición, leg. 1989, exp. 1, f. 306r.

107 Auto de 23 de septiembre de 1585, en AHN, Inquisición, leg. 1989, exp. 2, ff. 355r-356r. La inspección realizada con anterioridad, en ff. 352r-o․ 
la casa seleccionada y siguió de cerca las obras que fue preciso acometer, adoptando asimismo las necesarias resoluciones para su amueblamiento ${ }^{108}$. Concluida la visita, las cuestiones ya atendidas y otras muchas que, a su juicio, debían remediarse fueron puestas en conocimiento del Consejo.

En efecto, el Consejo insta a los visitadores a proponer las reformas que estimen pertinentes. No en vano, la visita general cumplía -a decir del entonces príncipe Felipe en referencia a las relativas al Consejo real y oficiales de la Corte, como recuerda Garriga ${ }^{109}$ dos finalidades:

Presuponese que en estas visitas se pretenden dos cosas: la vna saber cómo los oficiales se han auido en el vso de sus oficios, para castigar a los que se hallaren culpados y hazer merced a los que bien han servido; y la otra hordenar para adelante lo tocante a estos tribunales y oficios, dem anera en ellos aya el bueno y breue despacho que combenga.

La doble finalidad también en el caso de la visita inquisitorial es apuntada con carácter general, concretándose, en algún caso, el segundo de los objetivos apuntados en el "reconocimiento y revisión de los procesos tocantes a las causas examinadas por el tribunal visitado"110. En efecto, el visitador -como antes apunté- prestaba singular atención al estado de las causas fenecidas y pendientes de despacharse. Pero no cabe duda alguna de que la inspección del funcionamiento ordinario del Tribunal iba más allá.

De este modo, los informes emitidos por los visitadores permitían al Consejo tomar el pulso, en nuestro caso del Tribunal de Llerena, y percibir las necesarias medidas a emprender para mejorar su funcionamiento. Podían hacerse llegar a la Suprema durante la visita o, a su término, conjuntamente con el generalmente voluminoso expediente de la misma.

Pongo en noticia de V.A. que ya llegó el caso de concluir esta Visita -afirma Fabián de Cabrera en 1697- y que en este correo remito a la Secretaría de Cámara del Ex ${ }^{\text {mo }}$ Sr. Arzobispo de Valencia, Inquisidor General, todo el material que hauía quedado, que son los procesos [...] refiere seguidamente la documentación que adjunta y que no se había enviado previamente por haberse reconocido más tarde, y prosigue- También remito a $S$. Exa el quaderno de los autos de mi Comisión y cartas que me remitió S. Ex a tocantes a la visita, como también remito a V.A.el quaderno de Cartas que he reciuido en este tiempo, que se compone de 16 foxas, porque por acá no quede en el Secreto noticia de cosa alguna de lo que se ha obra en esta Visita ${ }^{111}$.

\footnotetext{
108 Auto de 17 de octubre de 1585, en AHN, Inquisición, leg. 1989, exp. 2, ff. 358r. El visitador había inspeccionado los nuevos aposentos ese mismo día y recibido las oportunas solicitudes por parte del notario de secuestros. Acerca de las diferentes sedes de la Inquisición de Llerena, GARRAÍN VILLA, L.J., "El Tribunal del Santo Oficio de la Inquisición de Llerena. Nuevas aportaciones", en XV Jornadas de Historia en Llerena, cit., pp. 311-329.

109 GARRIGA, C., “Los capítulos de la visita de Don Francisco Sarmiento a la Chancillería de Valladolid (1577)”, en INITIUM, 7 (2002), p. 964.

110 ALONSO, M.L., "La revisión del proceso inquisitorial según las visitas generales”, cit., p. 324.

111 Carta de Fabián de Cabrera de 26 de julio de 1697, en AHN, Inquisición, leg. 1994, exp. 18.
} 
En los expedientes de las visitas encontramos informes más o menos extensos, redactados a propósito con esa finalidad de trasladar al Consejo los problemas detectados, o con la de que se adopten urgentes medidas de mejora hasta en tanto pueda proveerse por parte de la Suprema:

[...] estando el señor Licençiado Villar, visitador, en la audiencia del Santo Ofiçio de la Inquisiçión, dixo que por quanto de la Visita que a fecho resulta auer necesidad de proueer algunas cosas para la buena expediçion de los negocios de este Santo Ofiçio, entre tanto que el Reverendísimo Señor inquisidor general y señores del Consejo de la General Inquisiçión proueen otra cosa, que mandaua y mandó que los señores inquisidores y los demás ofiçiales, según que a cada vno toca y tocar puede, guarden y hagan guardar los capítulos siguientes: Primeramente...112.

Se conservan también similares propuestas insertas en el informe general sobre la visita, aquel en el que el visitador repasa los cargos y traslada, al tiempo, su propia propuesta de sanción para los mismos. En otros casos, el visitador trata de trasladar su percepción acerca de la personalidad y forma de conducirse de los ministros del Tribunal de Llerena:

En cumplimiento de lo que V.S.I. y Rma me manda que, acabada la Visita de esta Inquisición de Llerena, la lleue o la embíe dando en ella mi pareçer, diré aquí lo que así de lo scripto, como de ynformaçion particular de personas graues de este lugar y del trato y comunicaçion que en seys meses que me he ocupado en hazerla he tenido con los inquisidores y oficiales de esta Inquisición, he colegido y me pareçe de las personas y modo de proceder de cada vno de ellos ${ }^{113}$.

Esos informes, que no son infrecuentes, adoptan la forma de "advertencias", "recomendaciones", "proposiciones", que es el título que he dado a este apartado en el que, para concluir, centraré la atención en algunas de las medidas o acciones de mejora trasladadas por "nuestros visitadores", o de otro modo resultantes de las visitas del Tribunal de Llerena. Para conocer el estado del Tribunal es de gran utilidad la información suministrada directa o indirectamente por los protagonistas de las visitas. Esto es, de una parte, por los visitadores -directamente en forma de memorial, o indirectamente como breves apuntes que se deslizan en otros informes, o mediante la adopción de medidas urgentes-; en segundo lugar, aunque en muy menor medida, por los inspeccionados y algunos testigos -que, en sus declaraciones ante el visitador dejan ver, en ocasiones con gran rotundidad, lo que a su juicio requiere mejorarse; finalmente, por la propia cúpula inquisitorial, a la que corresponde adoptar las medidas conducentes a las reformas que la visita ha evidenciado como necesarias. Esas medidas adoptarán en ocasiones la forma de decretos, cartas acordadas y, frecuentemente, se expresarán como "capítulos de visita", constituyéndose en una de las manifestaciones del derecho propio del Santo Oficio que se

112 Propuestas de mejora formuladas por el visitador Martín Villar el 28 de noviembre de 1565, en AHN, Inquisición, leg. 1989, exp. 1, ff. 783r-voo.

113 "Parecer del Inquisidor doctor Luis de Copones, sobre la visita que a hecho de los Inquisidores y oficiales de la Inquisiçión de Llerena”, en ibídem, exp. 11, núm. 1. 
incorporan a las extensas recopilaciones normativas elaboradas, fundamentalmente, en el siglo XVII 114 .

Los conocidos como "capítulos de visita" podían ser remitidos al Tribunal inspeccionado con antelación o, en ocasiones, tiempo después de haberse concluido la visita y dictado la correspondiente resolución. En otras muchas, no llegan a formularse tales advertencias, pero las recomendaciones que el Consejo hace llegar a los miembros del Tribunal conjunta o individualmente, se desprenden sin dificultad de los propios capítulos dedicados a cada uno de aquéllos en la Provisión de resolución de la visita, disponiéndose por el Consejo -del mismo modo que en los otros casos- que sean leídos y observados en lo que a cada uno corresponda por parte de los integrantes del Tribunal:

Por ende, por el tenor de la presente, encargamos y rogamos a uos, los dichos inquisidores y a los oficiales de esa Inquisiçion que ueáis esta nueba Prouisión y los capítulos en ella contenidos y los guardéis y cumpláis, guarden y cumplan, en lo que a cada uno de uso y de ellos toca en todo y por todo, según y cómo en ello se contiene y contra su tenor y forma no bays ni bayan en manera alguna, con apercibimiento que si lo contrario se hiçiere proueheremos cerca de ello lo que conuniere a la buena administración de la Justicia y mandamos que esta nuestra Prouisión y los capítulos de ella sean leydos y publicados en la Sala de la audiencia de esa Inquisición: lo que toca a uos, los inquisidores, en uuestra presencia y del fiscal y notarios del Secreto tan solamente y lo demás en la presencia de todos los demás oficiales y la lectura y notificación se asentará por el orden que se hiçiere como de suso ua declarado, para que ninguno pueda pretender ignorancia y se guarde y ponga en la Cámara del Secreto a buen recaudo juntamente con las Instruçciones, para que la persona que fuere a uisitar la uea y sepa si lo que por ella se mandó se ha guardado y cumplido y embíese testimonio al Consejo de la lectura, cumplimiento y execución de esta nuestra Carta ${ }^{115}$.

En relación al Tribunal de Llerena disponemos de abundante información, aunque desigual en volumen y entidad en cada caso, acerca del parecer manifestado por los sucesivos visitadores como resultado de la inspección realizada y asimismo procedente de las decisiones adoptadas por el Consejo en relación a algunas de las visitas. De las mismas se desprende, que se produjo un elevado número de intervenciones tanto de los visitadores como de la Suprema referidas a cuestiones de muy diversa índole. Aunque a primera vista pueda parecer que buena parte de las propuestas de reforma o recomendaciones dirigidas al Santo Oficio extremeño podrían catalogarse como medidas de mejora tocantes a sus ministros y oficiales, toda vez que estos son los responsables, en una u otra medida, de su correcta puesta en práctica, como lo son también de las malas prácticas que pretenden corregirse, el grueso de las medidas propuestas tiene que ver sobre todo con defectos en los

\footnotetext{
114 MARTÍNEZ NAVAS, I., "Recopilaciones de normas inquisitoriales. El Diccionario de las Leyes de la Inquisición de la British Library”, en International Journal of Legal History and Institutions, 2 (2018), pp. 101138.

115 "Prouision de la Resolucion de la Visita que hiço el licençiado Don Juan Çapata Osorio, Inquisidor de Seuilla, de los Inquisidores y ofiçiales de la Inquisiçion de Llerena”, en AHN, Inquisición, lib. 367, f. 72ํo.
} 
procesos, con la mala situación de algunas de las dependencias del Tribunal de Llerena como las cárceles o la Cámara del Secreto, o con su delicada situación financiera.

Sin pretensión, en ningún caso, de efectuar ahora una revisión del conjunto de recomendaciones que se formulan a los ministros y oficiales llerenenses a partir de las disfunciones detectadas en las visitas, las siguientes páginas se destinan a la transcripción de los informes, advertencias, recomendaciones o capítulos que se hicieron llegar en diferentes momentos al Tribunal de Llerena.

Se trata de seis documentos bien diferentes entre sí. El primero de ellos, fechado el 28 de noviembre de 1565, incluye aquellas medidas para la mejora del Tribunal de Llerena que su visitador ha considera imprescindible adoptar, sin perjuicio de que posteriormente el Consejo pueda resolver otra cosa. Es un documento suscrito por uno de los notarios del Santo Oficio extremeño que da fe de haberse procedido a la lectura de los doce capítulos formados por el visitador, tal como éste había dispuesto. El segundo de los documentos tiene su origen en el Consejo y está datado apenas dos años más tarde. Se trata en este caso de una carta dirigida a los inquisidores de Llerena en la que se trasladan diferentes consideraciones "en razón del buen gobierno y administración de las cosas del Santo Oficio". Su razón de ser no es la visita de 1565, o no sólo lo es esa visita. Se hace así referencia a unos apuntes remitidos por el fiscal llerenense a los que se da respuesta por parte del Consejo. Tanto la estructura como el contenido son muy diferentes a los de los restantes documentos transcritos. No se trata de una serie de capítulos numerados y/o ordenados, sino de respuestas a cuestiones concretas tan dispares como la mala situación de las dependencias destinadas a cárceles de la Inquisición de Llerena, la falta de suficientes notarios del Secreto o de un oficial encargado de la práctica del tormento, o la no demasiado buena relación entre los ministros que deriva en falta de coordinación en algunas de las tareas que se les corresponden por sus oficios. El tercero de los documentos, sin duda el más valioso, contiene las reflexiones del inquisidor que, en 1585, había visitado el Santo Oficio de Llerena, acerca de todos y cada uno de los problemas detectados en el mismo, así como las medidas a adoptar para resolverlas. El cuarto documento procede de nuevo del Consejo y está fechado en 1620. Se trata de más de una treintena de capítulos derivados de la visita realizada en ese año. Finalmente, el quinto de los documentos que transcribo contiene las propuestas de mejora a introducir en Llerena, trasladadas al inquisidor general y al Consejo por el visitador enviado a aquel tribunal a finales del siglo XVII.

En cuanto a las pautas seguidas en la transcripción, se han desarrollado las abreviaciones de palabras y eliminado las consonantes dobles; se ha regularizado el uso de mayúsculas y minúsculas; se han insertado entre corchetes aquello que no formaba parte del texto original; se han marcado diferentes párrafos, normalizado el uso de acentos y signos de puntuación, tratando de adaptarlos a las modernas reglas y, fundamentalmente, de facilitar su lectura.

IV.1. Medidas de mejora introducidas por el visitador Villar en 1565

En Llerena, veinte y ocho días del mes de nouiembre de mil e quinientos y sesenta y cinco años, estando el señor licençiado Villar, visitador, en la audiencia del Santo Ofiçio de la Inquisiçión, dixo que, por quanto de la Visita que a hecho, resulta auer 
necesidad de proueer algunas cosas para la buena expedición de los negocios de este Santo Ofiçio, entre tanto que el $\mathrm{R}^{\mathrm{mo}} \mathrm{S}^{\mathrm{r}}$ inquisidor general y señores del Consejo de la General Inquisiçion no proueen otra cosa, que mandaua y mandó que los señores inquisidores y los demás ofiçiales, según que a cada vno toca y tocar puede, guarden y hagan guardar los capítulos siguientes.

Primeramente, que guarden las Instrucciones y todo lo que por prouisiones y cartas particulares de los Superiores les está mandado. Y ansí lo cumplan y lo hagan leer dos vezes cada año en la audiencia, en presencia de todos los ofiçiales que para ello sean llamados. Y el fiscal enbíe al Consejo cada vez testimonio de cómo ansi se a fecho dentro de veinte días.

[2] Yten que los inquisidores no den tormento con vinagre, ni de otra manera nueua que no se aya vsado antiguamente en esta Inquisiçión. Y si se diere, que qualquiera de los notarios ante quien pasare, sea obligado, so pena de excomunión, de auisar luego de ellos al fiscal, para que lo tome por testimonyo y lo enbíe al Consejo.

[3] Yten que no permitan que el alcayde tenga companya con el despensero en las prouysiones de los presos, ni él por sí, ni persona de su casa, venda ni dé algunos mantenimientos ni otras cosas de su prouisión a los dichos presos.

[4] Yten que los inquisidores visiten las cárçeles cada quinze días sin faltar y siempre se ynformen de los presos si el alcayde cumple lo suso dicho y de lo demás que conuiniere. Y tengan mucho cuydado de proueerlos de lo necesario que ovieren menester y de proueer que no aya comunicación entre ellos.

[5] Yten den horden cómo combiene se resçiban las defensas que los reos tienen presentadas, de manera que sus causas no se dilaten, ni ellos tengan causa de quexarse.

[6] Yten que pongan edictos y llamen a los que conuiniere llamar a la defensa de la memoria y fama de los presos que han muerto dentro en las cárçeles, porque es justo que en sus causas se proçeda y porque, de no se hazer ansí, con la dilaçión podría ser que sus haciendas se consumiesen entre sí en alimentos y otros gastos.

[7] Yten que luego que se pone la acusación al preso, o se le diere la publicación de sus testigos, los inquisidores le manden dar y den treslado, para que él lo vea y pueda mostrar a su letrado y decir y allegar sobre ello lo que le paresçiere que le conuiene. [8] Yten que todo lo que proueyeren o mandaren pagar de los secrestos de los presos, o traer de ellos para sus alimentos, asiente en los dichos secrestos, quedando allí registrados los mandamientos que por la dicha razón manda prendar con día, mes y año.

[9] Yten que los notarios del Secreto, en las audiencias que escriuen en los procesos, asienten si es de la mañana o de la tarde, especialmente en las que se resçibe a prueua, o se ratifica algún testigo. Y en las del tormento el qual declare a qué hora comiença y se acaba y a qué hora se ratifica el reo de lo que dixo en él y declare la quantidad de la agua que se le echa y todas las otras cosas que allí pasan, lo más claro y specificado que ser pueda.

[10] Yten que el dispensero tenga libro en el qual, por mandado de los inquisidores, asiente vno de los notarios del Secreto el hordinario que mandan dar a cada vn preso 
y el acresçentamiento si lo mandaren hazer y lo demás que extraordinariamente se le mandare dar y proueer. Todo claro, con día, mes y año.

[11] Yten los inquisidores tengan cuydado que sus criados ni otras personas no entren ni anden en el huerto de la Inquisiçión, donde salen ventanas de las cárçeles, si no estando ellos presentes. Y las llaues de las puertas de las cárçeres que salen a la audiencia y capilla estén siempre en la Cámara del Secreto y de allí se tomen quando fuere menester.

[12] Yten que ni médico, barbero, partera, aluañiz, carpintero, peón, ni otra persona alguna entre en las cárceles sin hazerlo saber primero a los inquisidores, los quales les resçiban juramento primero de ellos que guardarán secreto y fidelidad, so las penas que ellos les pusieren. Y si se pudiere hazer, entre uno de los notarios del Secreto con ellos. Y el alcayde no los meta sin liçençia de los inquisidores por la dicha horden, so pena de excomunyón.

Los quales capítulos fueron leydos estando presentes los señores inquisidores liçenciado Arteaga y Moral, el bachiller Zanbrano, fiscal, Antonyo de Amezqueta y Françisco Yañes, notarios del Secreto, y Fernando Logroño, alcayde, a todos los quales el dicho señor visitador encargó mucho lo que en los dichos capítulos y les aduirtió de otras cosas necesarias, todo lo qual pasó ante mí, Sebastián Camacho, notario.

[AHN, Inquisición, leg. 1989, exp. 1, ff. 783r-vo]

\section{IV.2. Advertencias del Consejo en 1567}

A los inquisidores de Llerena en respuesta de unos apuntamientos que el fiscal presentó en el Tribunal en razón del buen gobierno y administración de las cosas del santo Oficio.

$\mathrm{R}^{\text {dos }}$ Sres: Por vuestras cartas de último del pasado y primero de éste y por la petición que ante vosotros presentó el liçençiado Serrano, fiscal de ese Santo oficio y de su relación, auemos entendido la mucha necesiad que ay de cárceles en esa Inquisiçión y los ynconuenientes que, de no averlas, se han seguido. Y, consultado todo con el $\mathrm{R}^{\mathrm{mo}} \mathrm{Sr}$ inquisidor general, a paresçido que, pues dezis ser vtiles las casas de don Luis Çapata para el remedio de la necesidad presente, se tomen por vn año, pagando por ellas de alquiler cinquenta mil maravedíes, como se a comunicado acá con doña Leonor de Ribera, mujer del dicho don Luis. Conuerná que luego deis orden cómo los presos se pasen a las dichas casas y se acomoden con mucha seguridad, y con el menos daño de las casas y costa del Oficio que ser pueda. Y hecho esto, si oviere aposento para vosotros señores todos tres, os pasaréis a biuir a ellos y si no, vos el $\mathrm{R}^{\mathrm{do}}$ licençiado Saluatierra podréis estar en ellas para tener quenta con el recado y guarda de las cárçeles y presos. Y las casas donde aora está el oficio se arrendarán. [2] Para la falta que dezis que ay en esa inquisición de notarios del secreto, su Sa $\mathrm{R}^{\mathrm{ma}}$ a proueydo dos que yrán con breuedad.

[3] De la Visita que ay hizo el licenciado Villar el año pasado de 65, resultó que en esa Inquisición no se auían visto las Instrucciones Nuevas, ni guardádolas, de lo qual, demás de algunos inconvenientes que se siguieron, vbo mucho aviso en el orden del 
proceder, en especial el poco recato que vbo en el secreto. Y conuiene que, de aquí adelante, pues los negocios son tantos y de tanta ynportancia, aya mucho recato y secreto. Y que fuera de los oficiales de él, nadie entienda ni sepa lo que en el audiencia y en el tormento y en otras partes pasa con los reos y presos por el crimen de la heregia, porque el secreto es lo principal para semejantes negocios. Y de la misma ymportançia es que estéis señores preuenidos en dexar libertad al ordinario y consultores de ese Santo Oficio para dar sus paresceres y votos en los negocios que vieren, porque de lo contrario se podrían seguir ynconuenientes y diferencias, como lo veréis por la Prouision que de la dicha visita se os enbio.

[4] Y por ella misma se os dio a entender quanto ymportaua que ouiese toda conformidad entre los Inquisidores y oficiales, por lo que ymporta a la expediçion de los negocios y al exercicio de Oficio tan sancto, porque aunque se entiende que hasta ahora la a auido y ay, se os aduierte para adelante y quando escriuieredes al Consejo firmaréis todos las cartas y, si alguno estuuiere de contrario parescer, le porna en la carta y lo firmará, porque el hazer lo contrario no se a de permitir.

[5] También conuiene aya mucho recato en el examen de los reos, quando començaren a confesar, en llamarlos y tener siempre audiencia con ellos hasta que ayan acabado sus confesiones. Y quando asi fuere confesando, se diferirá el ponerles la acusación, porque quanto a éstos no se entiende la Ynstrucción Nueva que dize que, hechas las moniciones, se les pongan a los reos las acusaciones, que ésto se entenderá con los negativos y no con los que van confesando.

[6] Aquí se a entendido que para las diligencias de los tormentos que en ese Santo Oficio se dan a los reos, se trae cada año vn verdugo de la ciudad de Mérida, el qual oye y saue lo que allí pasa, de que se pueden seguir muchos inconvenientes. Y consultado con su $S^{a} R^{m a}$, paresce que, para adelante, deueis señores proueer que el portero o el nuncio o un familiar de ese Santo Oficio, se ynstruya para que dé los dichos tormentos, asignándole por ello algún salario, como se haze en otras Inquisiciones. Y de lo que hiziésede, nos daréis auiso. Y porque los presos que al presente ay en esa Inquisición son muchos y casi todos tratantes, ocurrren muchas personas a tratar de deudas y tratos que tienen con ellos, será bien para el breue expediente de los negocios uno de los dichos tres señores, por meses, fuera de las oras de la Audiencia, se ocupe en ver las particulares que vinieren a ese Sancto Oficio y las prouea.

[7] Y quando el alguacil y oficiales de esa Inquisición fueren a hacer algunas prisiones de personas en número fuera de esa villa de Llerena, lleuarán dos o tres personas que sean familiares nombrados por vosotros señores, para que los ayuden, porque con esto se excusa mucha parte de costa y de otros yconvenientes que, enbiando los presos con personas naturales de los mismos lugares donde son vecinos los presos, se podrían seguir, pues el alguacil auiendo de hazer muchas capturas, no puede venir con todos.

[8] Días a tenemos auiso que en esa villa de Llerena ay falta de letrados que tengan las partes que se requieren para ser consultores y que al presente no ay mas de dos. Y por vuestros antecesores estaua recibido por consultor el bachiller Gómez 
Zambrano, hijo del licenciado Zambrano, que siruió muchos años el oficio de fiscal en ese Santo Oficio, del qual tenemos buena relación. Y consultado con su Sría Ilma, a parescido que, concurriendo en el dicho bachiller Zambrano las qualidades necesarias, le llaméis y admitáis por consultor. Y ansi mismo llamaréis por consultores a las Justicias de esa dicha villa, auiendo en ellos las partes que para ello convengan.

[9] Por carta del Consejo se os ordenó, en días pasados, hiziésedes recoger todas las cédulas de familiares del districto, para que se diesen en lista a las Justicias. Y después se os mandó hiziésedes boluer las cédulas a los dichos familiares, sin hazerles nuevas ynformaziones de su limpieza. Y porque se entiende ay entre ellos algunos infamados, consultado con su Sría Ilma, paresce que se hagan sus informaciones de nuevo y se reduzgan al número que, conforme a la Cédula de concordia de Su Magestad, a de aver. Los quales se den en lista a las Justicias de los lugares y staréis, de aquí adelante, muy aduertidos de no proueer familiatura, sino fuere la que vacare.

[10] Quanto al Breue que ay en ese Santo Oficio para comutar a los reconciliados la cárcel y hábito perpetuo en galeras, a parescido que se de noticia del dicho Breue al ordinario y consultores que han de votar sus causas. Y que en la sentencia que contra ellos se pronunciare, se ponga el tiempo en que van condenados a las dichas galeras. Y ternéis señores mucha consideración en la condenación de las dichas galeras quando los reos han dicho de cómplices y no están ratificados en sus dichos, cerca del orden que se deue tener con ellos, para que, de embiarlos a ellas, no se sigan ynconuenientes. Y en esto no se os puede dar más cierta regla, sino dexarlo a vuestra discreción y prudencia.

[11] Lo que toca a la prisión de algunos reos que se absentaron y pasan a Portugal, cuyas testificaciones serían de mucha importancia para los negocios de la fee, se a consultado con su Sría $\mathrm{R}^{\mathrm{ma}}$, y parece que se guarde la Concordia y orden que en esto ay en la Inquisición de Portugal. Y hazer se han las diligencias acostumbrdas quando sucedieren semejantes negocios. Y porque tenemos auiso que vn notario de la dicha Ynquisición de Portugal a estado ay, nos daréis auiso de lo que con él os resoluistes. Y porque se entiende que en poder de los inquisidores de Portugal está un Libro y memorial de todos los judíos que en estos Reynos y en aquéllos contribuyen para hazer una sinoga general en Salonique, escreuirles eys que, si es ansi que lo tienen, os embíen copia de lo que toca a estos Reynos. Y de lo que respondieren nos daréis auiso con toda breuedad.

[12] Vimos la respuesta que el prior de San Marcos de León dio a la Cédula Real que se le notificó para que no se entrometiese en negocios tocantes a la fee. Y si el dicho prior en algo ynnovare, darnos eis luego auiso, para que se prouea lo que convenga. [13] A Gerónimo de Salca se a notificado que, dentro de xx días, nombre y enbíe persona con su poder para que, en su nombre, se fenezca y acabe las quentas que tiene con Lorenço Ángel, preso en esas cárceles. Conuerná que no yendo la dicha persona a entender en las dichas quentas dentro del dicho término, deis señores 
orden cómo el receptor de ese Santo Oficio las fenezca y acabe. Y auisarnos eys de lo que de ellas resultare.

Guarde Nuestro Señor vuestras Rdas personas, en Madrid xxi de octubre 1567. Los señores don Ro de Castro, Busto de Villegas, doctor Gaspar de Quiroga, Francisco de soto Salazar, Juan de Ovando.

[AHN, Inquisición, lib. 576, ff. 115r-128r]

IV.3. Apuntamientos para los inquisidores de Llerena tocantes al modo de proceder con los reos

Unos apuntamientos tocantes al modo de proceder con los reos para los inquisidores de Llerena.

$\mathrm{R}^{\text {dos }}$ Sres: Receuimos vuestra carta del xx pasado y al Ilmo $\mathrm{Sr}^{\mathrm{r}}$ cardenal inquisidor general auemos significado lo que por ella decis, de que ya su Ilma tenía relación por la que el Consejo le a hecho y así a ofrecido de suplicar a Su Magd y a su Sa Ilma en las ocasiones que se ofrecieren:

Primeramente, que muchos reos son preguntados yn especie en lo que están dados por contestes y diminutos en sus confesiones, nombrándos les las casas y personas en particular, de lo qual se siguen ynconbenientes.

[1] Al primero capítulo parece que, estando los reos dados por contestes, precediendo primero las preguntas generales, sean preguntas yn especie, que los inquisidores traten y confieran primero lo que se deuiere preguntar a los tales reos. [2] Yten en las audiencias que se tienen con los reos se les hacen algunas preguntas no con el recato que se requiere y en los tormentos que se les dan todos los ynquisidores preguntan a los reos y asi el notario no puede escriuir lo que se les pregunta.

[3] Al segundo capítulo parece que así, de aquí adelante, si en las audiencias que se tubieren con los reos, como en las diligencias de tormento que se ouieren de hacer con ellos, solo el ynquisdior más antiguo pregunte al reo y que ninguno de sus colegas, ni el hordinario, puedan hacer pregunta. Y quando a alguno de los inquisidores o al hordinario pareciere se deue hacer más preguntas al reo, aduertirán con recato y secreto al ynquisidor más antiguo, para que él aga. Y si no la hiciere, después confieran los inquisidores sobre ello para ber si conviene se haga y lo que la mayor parte acordare aquello se executará.

[4] Yten en el dar de las publicaciones que se sacan en esta Ynquisción, quando algunos testificados de delictos cometidos en casa del reo se lo declaran diciéndole que hiço las ceremonias de la Ley de Moysen en su casa con otras personas, yendo contra la Ynstrucción y estilo del Santo Oficio.

[5] Al tercero capitulo parece que de aquí adelante se guarde lo dispuesto por la Ynstrucción nueua que es que no se dé lugar.

[6] Yten en esta Ynquisición está hordenado por el Consejo que las publicaciones de los que estubieren testificados de cosas tocantes a la Ley de Moysen se acuerden con el hordinario y consultores. 
[7] Al quarto capítulo, parece aquí adelante los inquisidores solos, sin el hordinario y consultores, voten las capturas de los que estuvieren testificados de la Ley de Moysen, con que antes de las executar embíen los procesos al Consejo, como está hordenado.

Madrid, 12 de hebrero de 1571.

[AHN, Inquisición, lib. 577, f. 208r]

IV.4. Malas prácticas y su remedio, según el visitador Luis de Copones

Relación de las cosas generales que han resultado de la Visita hecha por el doctor Luis de Copones, Inquisidor de Seuilla en la Inquisición de Llerena, el año de mil y quinientos y ochenta y çinco que pareçe tiene necesidad de enmienda y remedio.

1. Primeramente, por muchas ynformaçiones y otros recaudos que se han visitado en la Cámara del Secreto, que embían al Tribunal los comisarios del distrito ante quien pasan los negocios del Santo Oficio, ha parecido y pareçe que, en las más de ellas, ay faltas y defectos notables, así en las testificaciones como en las confesiones, ratificaciones y defensas, faltando a las vezes la hedad, otras el juramento, otras el reconocimiento del reo, pudiéndose hazer y siendo necesario para la substançia del proceso por no nombrado el testigo por su nombre. Todas estas faltas y otras proçeden de no tener los comisarios orden del Tribunal y Instruçión del estilo que en él se guarda y ellos están obligados a guardar para que todo vaya conforme.

Para el remedio de esto, se ha ordenado vna Instruçión de todo lo que común mente pasa y puede pasar ante los dichos comisarios, que se embía junta mente con esta relación y en ella se les da muy particular y puntual orden de todo lo que han de hazer conforme al estilo del Tribunal.

Esta Instruçión se a ordenado a los inquisidores que luego la embíen a todos los comisarios del distrito y que, de aquí adelante, quando se nombrare algún comisario, al tiempo que se le tomare el juramento y se le entregare el título de su comisión, se le entregue junta mente una semejante Ynstruçión. Y para que en esto no aya falta, remisión, ni descuydo, se manda al notario del Secreto ante quien pasare el despacho y refrendare el título, que no se le pueda entregar al comisario sin que junta mente le entregue también la dicha Ynstruçión y que de ello de fee y lo asiente en el libro donde se asientan los nombramientos de los comisarios para que conste, y no pueda el comisario decir que no se le dio para excusa de las faltas que hiziere. Y que el notario que en esto cometiere descuydo, de más de las penas en que incurren los ofiçiales que contravienen la Instrucçión, pague por cada vna vez quinientos maravedíes para ornamentos de la capilla y otros gastos extra ordinarios del oficio.

2. Vna de las mayores preeminençias y comodidades que esta Inquisición tiene es que los inquisidores y ofiçiales pueden sacar de los montes y dehesas comarcanas a esta villa toda la leña que, para el seruiçio de sus casas, han menester, la qual es muy buena, toda de enzina.

De esta prehemineçia y comodidad se ha venido a vsar en tanta manera que ay grandísimas quexas y contínuas exclamationes de todos los Conçejos cuyas son las 
dichas dehesas, quexándose que se las tienen del todo arruinadas y sin monte y abrigo para los ganados, cortando muchas vezes las mejores ençinas y talándolas por el pie, sacando sin comparación mucha más leña de la que para el seruiçio de sus casas es menester y avn vendiéndola alguna vez públicamente en la plaza.

Este tan gran desorden ha proçedido y procede de que, de algunos años a esta parte, los dichos inquisidores y ofiçiales, para aorrar la costa de la traída de la dicha leña, buscan leñadores cosarios y les dan çédulas y mandamientos para que, cada vn día, con dos vestias, saquen leña de las dehesas, ha partido. El qual es que de seys cargas que sacan, las quatro son para el leñador y las dos las pone, sin costa ninguna, en casa del inquisidor o oficial, de manera que, si al año son menester para seruiçio de casa del inquisidor çient cargas de leña, se sacan de las dehesas treçientas y a este mismo respecto si más son menester.

Y demás de esto dan muchas cédulas juntas y para diferentes dehesas, hallende de que los leñadores, como son cosarios, a sombra de las dichas çédulas, sacan mucha más quantidad de leña de lo que por las dichas cédulas se les permite.

Todo lo qual, es muy gran cargo de conçientia y a dado ocasión a los Conçejos de hauerse quexado en el Consejo Real de Su Magestad y pedido prouisión para que esta comodidad se quite a la Inquisición, la qual ymporta muchísimo conserualla. Y el medio para ello es quitar los abusos y deshórdenes y poner orden qual conuenga para que ellos y las quexas cesen.

El que pareçe sería conueniente es que las cédulas y mandamientos de sacar leña se den sola mente para las casas de los inquisidores y ofiçiales que tienen título del Ilmo Sor inquisidor general y no para otras personas algunas, como se entiende se a hecho. Y que éstas se den sola mente para lo que cada vno huuiese menester para el seruiçio de su casa, tasando esto de una vez en el Tribunal conforme al gasto que cada vno tuuiere. Y que ninguna de estas çédulas ni liçençia la pueda dar ni dé ninguno de los inquisidores particularmente, sino que se aya de despachar y despache por el Tribunal en forma, firmada de todos los inquisidores, o de los que residiesen y refrendada por vno de los notarios, el qual no la pueda despachar ni refrendar sino con acuerdo de todos, o de los que residieren y hauiendo la primero asentado y registrado en el libro y quaderno particular que para estas çédulas ay en el Secreto, para que por él se vea si alguno exçede de la quantidad de leña que para su casa se le a tasado. Y que cada vno de los inquisidores y ofiçiales esté obligado a hazer traer la leña con sus bestias propias y criados si los tuuiere y con vestias y criado alquilado y pagado a dinero y no en alguna manera a trueque de leña, para que no se pueda sacar más de la que cada vno huuiere menester.

Y que de esta orden se de notiçia a los Conçejos cuyas son las dehesas, para que tengan cuydado que se guarde, con lo qual se entiende estarán muy contentos y darán de buena gana toda quanta leña fuese menester y avnque le cortarán y harán traer a su casa, lo qual podían los inquisidores tratar en los Conçejos y asentarlo con ellos de manera que sea çierto y perpetuo, antes de poner en execuçion lo contenido en este capítulo y que para la guarda de esto, o de lo que con los Conçejos se 
concertare, se les pongan a los inquisidores notarios y otros ofiçiales las penas que a V.Sa IIma, le pareçiere.

3. En los años que son estériles y ay falta de pan, acostumbra la Inquisición, conforme a las Çédulas Reales, dar mandamientos para que saque de los labradores del distrito el pan que es menester para la prouisión de los inquisidores, ofiçiales y presos, a la tasa de Su Magistad. Y ansí como esto es forçoso se haga, porque de otra manera, según vienen a ser en semejantes años exçesiuos y desaforados los preçios del pan, sería imposible poderse substentar. Es también muy necesario que en esta saca de pan aya orden y conçierto y no se de ocasión a las muchas quexas que, en estos años atrás, acerca de esto ha hauido, en los quales se entiende se a exçedido muy notablemente, asi en sacar mucha quantidad más de la que hera menester y hauer se amasado y hecho grangería de ello, como en hauerse sacado para personas fuera del Oficio y mercaderes confesos, de lo qual a auido murmuración y resultado nota al Oficio. Y ansimismo de que, demás del mandamiento, o mandamientos generales que por el Tribunal se han despachado para prouisión del Oficio, sean despachado otros mandamientos en nombre de él por vn sólo inquisidor, o por los dos sin comunicarlo con el terçero. Y con semejantes mandamientos se a sacado mucha quantidad de pan de más de la que para prouisión de las casas de los inquisidores y ofiçiales se ha sacado por virtud del mandamiento general.

El remedio y orden que en esto pareçe puede auer es que quando la disposición del año pidiere que, en nombre y con mano del Oficio, se aya de sacar trigo para la prouisión de él, que al tiempo de hazerla, se haga en el Tribunal lista y memoria de todo el pan que fuere menester, señalando y tasando a cada vno de los inquisidores y ofiçiales lo que conforme a las personas y gasto que en su casa tienen pueden gastar. Y asi mismo el que verisimílmente fuere menester para los presos, señalando persona que reçiua todo el dinero y de toda esta quantidad junta se despache por el Tribunal mandamiento dirigido a la persona o personas que les pareçiere conuenir para que lo saquen donde con más comodidad y menos pesadumbre se pudiere. $Y$ que de todo lo que sacaren ayan de tomar fee y testimonio y presentarlo en el Tribunal para que se vea y entienda si se ha sacado ninguna más quantidad de la contenida en el mandamiento y paresçiendo se castigue con mucho rigor y que no se pueda dar ni despachar otro ningún mandamiento en nombre del Tribunal, sino fuere en caso que, por hauer sobreuenido muchos presos, parezca ser necesario sacar más quantidad para sus alimentos, lo qual se haga con toda moderaçión y límite y sólo lo que para ellos fuere menester. Y que estos mandamientos ayan de yr firmados de todos los inquisidores o de los que residieren y que, de otra manera, no pueda ninguno de los notarios refrendarlos ni despacharlos, so las penas puestas por Instrucçiones y demás de ellas pague, por cada vez que lo contrario hiziere, dos mil maravedíes para gastos del Ofiçio.

4. Como el distrito de esta Inquisiçión es muy grande y ay en él muchos familiares, son muchas las causas criminales de ellos que de ordinario se tratan y penden en el Tribunal. Estas se alargan mucho, en muy gran perjuicio y costa de las partes y embaraçan demasiadamente los negocios y causas de fee y padesçen los presos en 
las cárçeles secretas, porque se ocupan todos los tres inquisidores por lo menos vna hora o más en el principio de las audiencias y muchas vezes toda la audiencia entera y hartas vezes naçe entre ellos discordia sobre el probeher el término o dilaçión y otras cosas semejantes de poca ymportançia. Y por esto y por otras ocasiones no se probehen las peticiones de las partes, sino que las mandan poner en el proceso y ansi se queda sin que la vna parte ni la otra sepa que es lo que a de hazer o pedir. Y asi mismo, muchas vezes, avnque se prouean las peticiones, no se da no se da [sic.] notiçia a las partes hasta la fin de la audiencia y han de estar allí perdiendo el tiempo y las más se las dexa el notario en el Secreto con lo probeydo, de manera que en esto ay mala orden y poco estilo.

Pareçe podría ser conueniente remedio para el breue y buen despacho de estas causas, si V.S. Ilma mandase que éstas y semejantes las oyese y tratase solo un inquisidor en audiencia de por sí, por su turno, quatro meses del año cada uno, començando el más antiguo y después consecutivamente los demás ante vno de los notarios del Secreto, ansimismo por su antigüedad y turno para que a todos les cupiese parte de esto. Y faltando, por enfermedad u otro impedimento, le subçediese el siguiente y que este inquisidor sólo proveyese las peticiones luego allí en la audiencia, mandando dar traslado a la parte en lo que conuiene dárselo y substanciando todo el proceso hasta concluirle, consultando con sus colegas, si en algunas cosas se le ofresçiese dubda. Y concluso difinitiuamente, le votasen todos juntos en el Tribunal. Y que en cada audiencia estuuiese obligado el notario despachar todas las peticiones y dar luego notiçia de lo probeydo a las partes, porque de esta manera, seguir se han con buen estilo las causas. Y criando vno sólo el proceso y tratándose cada el día estará muy bien en lo que se ha de probeer y no como agora que cada vez es menester hazer relación de nueuo qué proceso es el que se trata y en qué estado está y no se açierta a probeher lo que conuiene.

5. En las causas de apelación fiscales de hazienda de duizientos ducados abaxo que vienen del juez de bienes al Tribunal, a hauido y ay grandísima remisión y negligencia y en llegando a él se hazen ynmortales y nunca se terminan. Y las vezes que se a de probeher alguna cosa en ellas, se ocupa en ello todo el Tribunal lo que es de mucho yncombeniente para los demás negocios y podría se con mucha facilidad remediar por la misma forma del capítulo precedente, mandando V.Sa Ilma que el dicho inquisidor sólo en su audiencia, substançiase todos estos proçesos hasta concluyrlos deifinitiuamente y conclusos los determinasen juntos los inquisidores en el Tribunal.

6. En estas mismas causas de apelación que vienen del Juzgado de bienes al Tribunal se a yntroduçido en esta Inquisición vna costumbre que pareçe fuera de razón. Y es que reçeuida la causa en grado de apelación en el Tribunal, las partes para presentar las peticiones en ella trahen consigo al escriuano del Juzgado de bienes que es ante quien pasó el proceso de la primera ynstançia. Y ante él presentan en el Tribunal las peticiones. Y los inquisidores las probehen y hazen ante él, los auctos y otras vezes los hazen ante uno de los notarios del Secreto, de lo qual resulta mucha confusión y poco despacho en las causas y es cosa muy fuera de todo Derecho y estilo de otras 
Inquisiçiones que, reçeuida la causa en el Tribunal superior, se hagan los auctos con otro scriuano que no sea del Tribunal y más que sea con el scriuano del juez inferior y haga auctos en el Tribunal en presencia de los notarios del Secreto.

Pareçe conuendría que V. Sa Ilma mande se guarde aquí lo que en esto se guarda en la Inquisición de Seuilla y es que al tiempo que se presenta alguna parte en grado de apelación en el Tribunal se reçiue el apelación y se manda al scriuano del Juzgado que trayga el proceso y haga relación de él en suma en el Tribunal y hecha entregue el proceso al notario del Secreto que asiste en la audiencia y de allí adelante no se entremete más en el negocio. Y todo lo que en él se haze y provee es ante los notarios del Secreto y del Tribunal, que pareçe buen orden.

7. Ansimismo, por muchos proçesos que se han visitado del Juzgado de bienes, de causas que en él penden de hazienda del fisco, se ha visto que ha hauido y ay tan gran descuydo y negligencia en los ministros que las tratan, especialmente en el procurador del fisco, que quasi en todos ellos se halla que se pasan dos años y año y medio, y por menos siete y ocho meses, sin que se dé petición ninguna, ni se haga diligençia. Y como las mas causas son de cosas menudas, viene se a perder con tanta dilation y se pierde también la ocasión de hazer las prouanças y por falta de ellas quedan los proçesos sin substançiar y la Hazienda perdida.

Para remedio de esto y para que las causas se vayan de ordinario siguiendo sin estas ynterruptiones, pareçe conuiene que V. Sa Ilma mande que dos días cada semana, el lunes y jueues, se junten el abogado del fisco y el procurador en el aposento donde estuuieren los papeles del Juzgado, u otro que sea a propósito para esto. Y allá, por el memorial de todas las causas pendientes que está obligado a traer el procurador del fisco, se ordene en cada proceso, según el estado en que estuuiere, lo que conuenga y lo lleue el procurador para presentarlo ante el juez de bienes. teniendo cuydado de que se hagan las notificationes luego a la parte. Y para que se entienda lo que en esto se haze, sean obligados el dicho abogado y procurador, o el vno de ellos, cada día de estos después de acauada la Junta, dar quenta de todo lo que en ella se huuiere hecho al inquisidor más antiguo, el qual vea si se ha hecho lo que conuiene y les ordene lo quele paresçiere faltar por hazer.

8. En todas las Inquisiçiones es estilo y costumbre conforme a Derecho, Instruçiones y Cartas Acordadas que, residiendo todos los Inquisidores en el Tribunal y lugar de él, ninguno de ellos particularmente y por su sóla authoridad proçeda a prender ni castigar ni reprehender persona alguna, ni hazer otros auctos tocantes al Tribunal, sino juntos todos los Inquisidores que residen. Y de no hauerse esto guardado en esta Inquisición ay mucha quexa y se han seguido ynconuenientes y el Tribunal ha venido a perder mucha authoridad y los Inquisidores a ser tenidos en poco, por querer cada vno particularmente y en su casa vengar y castigar las ofensas que a sus personas o de criados suyos se han hecho, haziendo prender algunos y castigándolos sin acuerdo ni conmunication de sus colegas. Y aunque esto les está vedado por las dichas Instrucciones y cartas, como no se han guardado ni guardan, conuiene que V.S Ilma $^{-}$de nueuo, con censuras y graues penas, mande a los Inquisidores que en 
esto no exçedan ni pasen de lo que les está ordenado y que no se prenda ni castigue ninguno sin que proçeda legítima información.

9. De hauer algunos de los notarios del Secreto despachado mandamientos y otras cosas en nombre del Tribunal, por orden y firmados de solo vn inquisidor, o de dos sin cominication y acuerdo de los demás colega o colegas, se a dado muchas vezes ocasión a diferençias y discordias entre los inquisidores y a que se ayan hecho algunas cosas yndeuidas de que a auido mumuraçion y nota. Conuiene para remedio de esto que se mande a los notarios del Secreto que no refrenden ni despachen mandamientos, ni otros despachos ningunos en nombre del Tribunal que no sean comunicados y acordados y firmados de todos los inquisidores que residieren en el lugar del Tribunal, so pena de dos mil maravedíes para gastos del Santo Oficio, por cada vna vez que lo contrario hizieren, los quales se les lleuen y executen con rigor, saluo en los casos y negocios en que, lo que la mayor parte de los inquisidores determinan, se ha de executar y despachar, sin embargo de la discordia y contradition del terçero, porque en estos casos el notario ante quien pasare despachará los mandamientos y otros recaudos que la dicha mayor parte le mandaren, firmados de los que lo determinasen, avnque el que huuiere discrepado no quiera firmarlos, con que en los proçesos o auctos que se a sentado el voto y contradition del que huuiese discordado y no de otra manera, so la dicha pena.

10. Muchas vezes los comisarios, familiares y otras personas, embían al Tribunal despachos o cartas con auisos de cosas de fee y otras importantes, çerradas y selladas, dirigidas al Tribunal. Y han acostumbrado algunos de los inquisidores y ofiçiales reçeuirlos y abrirlos. Y tocando a algunos de ellos, o parientes y amigos suyos, pueden fácilmente encubrirlo y se queda sin remedio, ni castigo, como se sospecha se ha hecho algunas vezes. Y otras, viniendo despachos de la Corte, hauerse tornado cartas y recaudos que venían para algunos del Oficio y escondídolos, de manera que nunca han parecido.

Para remedio de todo esto, conuiene que se mande, con graues penas, que ninguno de los inquisidores ni ofiçiales pueda reçeuir ni reçiua pliego, despacho, ni carta que venga çerrado y sellado para el Tribunal, sino mandar al que lo trahe lo lleue al Tribunal y en él se avra por ante vno de los notarios del Secreto, siendo día de audiencia. Y siendo fiestas o vacaciones, se lleue y entregue al inquisidor más antiguo y no a otra persona alguna, el qual le tenga çerrado y sellado para le lleuar al Tribunal, para que allí se avra en la forma dicha, si ya no se ofreciesen dos o tres o más fiestas, o fuese tiempo de vacaciones y se entendiese, o se presumiese verisimilmente que el negocio podría ser de ymportançia, como si fuesen despachos del IImo Sor Inqor general, o Consejo y se temiese que en la dilaçión podría hauer peligro, o daño, que, en qualquiera de estas cosas, el inquisidor más antiguo a quien, como dicho es, se an de entregar los despachos, podrá, si le paresçiere, llamar con el portero a su casa el colega, o colegas que residieren y juntos, por ante vno de los notarios del Secreto, abrir los despachos y excusando se los colegas, el dicho inquisidor antiguo, por ante el dicho notario, y ordenar y probeher lo que conuiniere. 
11. Entre los inquisidores a hauido algunas vezes diferençias y alteraciones sobre si las confesiones de los que voluntariamente se vienen a deferir, se han de reçeuir y scriuir en el Libro de las testificaciones, o en papel de por sí. Y por que, en lo vno y en lo otro, se pueden ofreçer yncombenientes, porque scriuirse en el Libro de testificaciones pareçe mal orden y poca claridad y ocasión de que façilmente se oluiden entre las testificaciones y scriuiendose en papel de por sí, no siguiéndose luego la causa con el reo y haziéndose proceso con él, las más vezes al tiempo que se busca, no se halla en tanto número de papeles sueltos como acuden y cargan.

Y para remedio de lo uno y de lo otro, pareçe conuiene que se haga vn quaderno con su abecedario, intitulado de confesiones espontáneas, en el qual se reçiuan y scriuan todas las semejantes confesiones y no otra cosa alguna mezclada y luego se saque el nombre del reo al abecedario y quando se hubiere de hazer proceso con él, sacarse ha del quaderno la confesión y, mientras no se haze, quedará en lugar çierto y seguro y se hallará siempre que fuere menester.

12. Los legajos de los proçesos determinados, que están en la Cámara del Secreto, que son en mucho número, no pareçe que están con el deuido orden, ni con la seguridad que conuiene, porque, en cada vno de los dichos legajos, está mucho número de proçesos y todos sueltos, que solamente tiene un pedaço de pergamino por arriua y otro por auaxo, liados con cordeles delgados. Y quando se ha de buscar un proceso, es menester reboluer casi todo el Secreto y va muy a la ventura topar con él, por no tener los dichos legajos repertorio, al principio de cada vno de ellos, de los proçesos que en el ay. Y está muy en la mano de cada vno de los ofiçiales del Secreto sacar de él y desaparecer los proçesos que él quisiere, pues estando como están sueltos, aguardando la ocasión, lo puede hazer en vn ynstante, sin que jamás se pueda caer en ello, lo qual es negocio muy peligroso y tiene necesidad de remedio. Este podría ser mandando que cada vno de los dichos legajos se enquaderne en muy buenos pergaminos con todos los proçesos que en él ay y de manera que se correspondan con el repertorio general y por él se puedan hallar y en cada principio del legajo se ponga repertorio de todos los proçesos que en él ay, el qual bastará sea por números vno, dos, tres, etc, porque en ningún legajo se juntan tantos que, avnque no sea el repertorio por abecedario, no puedan por el número fácilmente hallarse. Y con esto çesará también el peligro de sacarse ni rehundir ningún proceso. 13. Están en la Cámara del Secreto dos libros grandes enquadernados que son registros de los sanbenitos que están puestos en esta villa y por todo el distrito de esta Inquisición. Estos están en tan mala orden y tan confusos y mezclados los vnos con los otros, que, con gran dificultad, se pueden hallar los que se buscan. Porque demás de esta confusión, en los más de ellos, no ay razón de qué lugares son, ni quándo, ni con qué orden se pusieron. Y esto conuiene se remedie con breuedad, porque, enbejeçiendose de esta manera, vendrá a faltar del todo la razón de ellos y quedar ynútiles y sin que puedan hazer fee los registros. Y así, se ha mandado que estos libros se desenquadernen y se tornen a poner de nueuo en buena orden, de manera que todos los sambenitos que se han puesto en esta Villa estén consecutiuamente y por sus tiempos y sin mezcla ninguna de otros lugares y lo 
mismo sea en cada vno de todos los demás lugares del distrito donde se huuieren puesto sambenitos, poniendo la razón de qué lugar son y por qué tiempo se pusieron y por quién y con qué orden. Y estén los dichos libros foliados y en el principio de cada vno de ellos su repertorio por abecedario de todos los lugares de que en el libro ay sambenitos y en qué folio cae cada lugar, lo qual tenga a cargo de hazer el fiscal, con vno de los notarios, dentro de ocho meses siguientes.

14. En el Libro de penas y penitencias ay muchas partidas asentadas en que no parece si de ellas se a dado notiçia al receptor o no y otras muchas en que, avnque el notario del Secreto que la asienta dize en el cuerpo de la partida, o en la margen de ella, diose notiçia al receptor, no asienta el día, ni tiempo en que se le dió, lo qual es necesario para que, en las quentas que se le toman, se vea si a tenido negligencia en la cobrança y se le pueda hazer cargo.

Pareçe conuiene que se mande a los notarios del Secreto que tengan muy particular cuydado, en asentando la partida de pena o penitencia en el Libro, de dar fe cómo se dio notiçia al receptor o al que hiziere el oficio, juntamente con el día en que se le da. Y que, el que en qualquiera de estas cosas cometiere descuydo, cayga por cada vna vez en pena de duzientos maravedíes para gastos extraordinarios del Ofiçio.

15. De mucha ymportançia sería que en el Secreto se truxese vn Libro de registro general donde quedasen registradas las cartas que se scriuen y auctos que se probehen en cosas de la fee y otras de substançia tocantes a negocios del Tribunal, porque, de no hazerse, resulta mucha ceguedad en los negocios y como no ay memoria de los pasados, ni exemplo de lo que en ellos se a hecho, cada vez que subçeden vienen muy de nueuo y acontece hazerse determinaciones muy diferentes y contrarias de las que en otros casos semejantes se han fecho, que causa nota en el Tribunal. Y acontece también hauerse de scriuir a los comisarios y a otras Inquisiciones dos y tres vezes sobre vn mismo negocio y no se tiene notiçia de lo que escriuió, ni de quánto tiempo ha, de lo qual resulta darse diferentes órdenes en una misma cossa. Y avnque esto de este registro sería muy necesario y lo es en qualquier Tribunal, pero como forçosamente abría de hauer para ello sólo un oficial y tendría bien en que entender.

Pareçe que, a lo menos, conuiene que se prouea que, todas las cartas que se scriuieren a otras Inquisiciones, o comisiones, o otras personas en negocios de fee y otros graues y de ymportançia, el notario del Secreto que las scriuiere registre la data y la substançia de lo que se scriue en vn Libro de registro que para esto se trayga, para que siempre que sea necesario se sepa a dónde se a de acudir para sauer lo que en el negocio se a scripto y quánto há que se scriuió.

16. Por Instruçión está ordenado y mandado al fiscal que asista en el Tribunal a las consultas a la vista de los proçesos y es de mucha ymportançia, para que, como quien ha criado los proçesos, pueda aduirtir en ellos de muchas cosas que, los que solamente los oyen relatar, fácilmente pueden dexar de caher en ellas. El fiscal de esta Inquisiçion nunca a asistido ni asiste a ellas y lo mismo entiendo es en las demás Inquisiçiones, por ocasión de que por la Ynstruçión se le manda al fiscal que tenga el vltimo lugar en la consulta después de todos los consultores. Y como en todos los 
demás actos del Tribunal suele tener el lugar ynmediato después de los inquisidores, hagásele muy de mal esta mudança. En esta Inquisición pareçe podría esto fácilmente remediarse, porque el ordinario y consultores se sientan todos consecutiuamente a la mano derecha del Tribunal y en la signiestra no se sienta alguno y aquella mano sería lugar conueniente donde el fiscal, en su silla, asistiese, porque estando sólo en aquella mano, sin concurrir con otra persona alguna, no pareçe lugar ynferior a los demás, pues él no ha de dar voto.

17. He hallado también en esta Inquisición costumbre que el fiscal asiste en el Tribunal en su silla a los principios de las audiencias por la mañana y por la tarde, todo el tiempo que se leen y proueen las peticiones de las partes que trahen pedimentos y otros negoçios que se ofreçen, en lo qual de ordinario se gasta vna hora o más cada audiencia y muchas vezes todas ella entera. Y demás que esto no toca al oficio del fiscal y quando ay cosas, de que se le aya de dar notiçia, se le manda dar traslado y se le notifica por los notarios del Secreto, a sido algunas vezes de yncombeniente, viniéndose atrauesar con los inquisidores, o alguno de ellos, sobre el proueer de las peticiones por ayudar y fauoreçer algunos amigos. Y lo que es mayor y más çierto daño, que todo el tiempo que en esto gasta el fiscal, lo pierde en lo es su oficio y negocios de fee, a que a de asistir en el Secreto. Y así conuiene que en esto se ponga orden y que V.Sa Ilma mande que el fiscal, acauada de oyr misa por la mañana y por la tarde, en viniendo y abriendo el Secreto con su llaue, se entre en él y entienda en las cosas de su oficio y no asista en el Tribunal, ni salga a él sino quando los inquisidores le llamaren para los auctos que huuiere de hazer, o quando tuuiere que presentar denunçiaçiones o acusaciones y cosas de su ofiçio.

18. También he notado que los notarios del Secreto, quando asisten en el Tribunal a las audiencias con los inquisidores, se sientan a la caueçera de la mesa, a la mano yzquierda de ella, junto al Inquisidor más nueuo. Y el asiento que tienen es silla de respaldo y delante sobre la mesa vn atril alto en que scriuen, en lo qual pareçe ay dos yncombenientes. El vno, que estar el notario en el Tribunal sentado en silla de cuero con respaldo y scriuiendo con atril alto, es poco respecto del Tribunal y contra lo que V.Sa Ilma y el Consejo, por Carta Acordada, tienen mandado que los dichos notarios en el Tribunal no puedan sentarse sino en banquillos. El otro, que estando en la caueça de la mesa está desacomodadamente en respecto de los dos inquisidores más antiguos y de los reos con quien se haze audiencia, que está muy lexos enfrente del medio de la mesa.

Pareçe conuiene que en esto V.S Il $^{\text {ma }}$ mande que los notarios en el Tribunal se sienten en medio de la mesa, en frente del inquisidor más antiguo, teniendo a su lado siniestro y muy cerca al reo con quien se haze audiencia y que escriuan en la mesa, sin atril ninguno, y estén sentados en banquillos como V.S Ilma $^{\text {ma }}$ tiene mandado y se guarda en la Inquisición de Seuilla y entiende que en las demás.

19. Asimismo conuiene que V.S Ilma mande a los inquisidores que, estando en el Tribunal, ninguno de ellos se descubra ni quite el bonete a los notarios del Secreto, ni a otro algún oficial, ni los traten de merced, sino al fiscal y juez de bienes, porque demás que es descompostura y desauthoridad del Tribunal, a sido y es muy de 
ordinario ocasión que, como en esto no ay orden çierta, y vnos inquisidores tratan en el Tribunal a los ofiçiales con diferente cortesía que los otros, naçe entre ellos y los ofiçiales rancores y diferençias y discordias, lo qual todo çesará sauiendo los ofiçiales que es ordenada por V.Sa Ilma al Tribunal.

20. Avnque por Ynstruçiones está mandado que sólos los inquisidores, fiscal y notários del Secreto entre en la Cámara de él y no otra persona alguna, en esta Inquisición no se puede esto guardar, como conuendría, por estar dentro de ella y entre los papeles el arca del dinero de las tres llaues y ser forçoso, cada vez que se ha de meter o sacar dinero, que entren en el Secreto el receptor y el notario de los secrestos y, con esta ocasión, algunas vezes el alcaide y portero, lo que es de ynconueniente, por poder con facilidad ver papeles algunos de cosas secretas y alguna vez, o de industria o descuydo, lleuar alguno de ellos, como se dize haya aconteçido.

Pareçe se puede remediar con que, o en la segunda audiencia, o en otro lugar a propósito, se acomodase vn aposentillo donde, con ygual seguridad y sin estos ynconuenientes, estuuiese puesta y guardada el arca del dinero.

21. Los más de los familiares que los inquisidores nombran, los amiten sin conoçerlos ni verlos, de que muchas vezes resulta ser personas desauthorizadas y totalmente ynvtiles para el seruiçio y Ministerio del Ofiçio. Y muchas vezes embían a sus lugares los títulos y orden al comisario más çercano que les tome el juramento. Y lo mismo se haze también con muchos de los comisarios, que es de mucho más peligro. Y así, conuiene que V.Sa Ilma mande y encargue muy estrechamente a los inquisidores que, sino fuere teniendo ellos, o alguno de ellos, muy particular notiçia y conocimiento de la persona que pretendiese ser familiar o comisario y seguridad de que tiene las partes que para ello se requieren, no admitan a oficio ninguno de estos a persona que no parezca personalmente en el Tribunal, para que le vean, traten y conozcan. Y asimismo, que sino fuere con muy preçisa y vrgente causa, no se embíen ni den los títulos, ni se cometan los juramentos de familiares, ni comisarios, fuera del Tribunal, sino que vengan a prestar el juramento y reçebir el título e Instruçión al Tribunal, donde sean aduertidos de lo que han de hazer y del término que han de tener. Y que también los inquisidores aduiertan a todos los comisarios del distrito que tengan mas cuydado de lo que hasta agora han tenido y tienen en hazer las ynformaçiones de las limpieças, porque ay hartos familiares por el distrito que ellos, o sus mugeres, o entrambos, están muy notados e infamados de tener raças de judíos o moros.

Açerca de lo qual queda mandado al fiscal y inquisidores que hagan las ynformaçiones y diligencias que conuengan para la aueriguación y con su parecer, conforme a la Carta Acordada, las embíen al Consejo para que se prouea lo que conuenga. Y que pues la experiencia muestra que se puede tener poca confiança de los comisarios en esto, que las vezes que a los inquisidores les pareçiere y no tuuieren entera satisfaçion del comisario o comisarios, embíen persona del Oficio de confiança a hazer las ynformaçiones. 
22. Las ynformaçiones que se huuieren de hazer para consultores y abogados y otras personas que tratan las cosas del Secreto, pareçe que conuiene se hagan por alguno de los notarios del Secreto, o por el de secrestos, por ser de más qualidad que las de familiares y comisarios y importar que se hagan con mucho cuydado y diligençia. 23. En esta Inquisición ha hauido y ay costumbre inmemorial, confirmada por muchos actos positiuos, como también la ay en las demás Inquisiçiones, que los ofiçiales de ella, en todas sus causas criminales y çiuiles, así siendo actores como reos y conuenidos, tratan todas sus causas ante los inquisidores y en su Tribunal. Y, de dos años a esta parte, no más ay en esto alguna alteración y mudança, por ocasión de los encuentros y diferençias que don Alonso del Castillo, gouernador de esta Prouinçia, a tenido con la Inquisición. Y, desde entonces, ha querido pretender que, lo que se les deue a los ofiçiales de la Inquisición, lo han de pedir a los deudores en su Tribunal y no en el de la Inquisición, lo qual es tanta nouedad y tan perjudicial, que los más de los ofiçiales dexan de pedir lo que se les deue, por no consentir en el perjuicio. Y se ha dado muchos días ha quenta al Consejo y embíado por su orden, de aquí toda la claridad y vastísima ynformaçion de esta costumbre inmemorial y prescrita y diuersas vezes confirmada con actos positiuos en contraditorio.

Conuiene mucho que V.Sa IIma mande que esto se torne en su lugar con breuedad, porque padesçen mucho los ofiçiales y les sería de grandísimo daño hauer de pedir sus deudas fuera del Tribunal y forçoso perder mucho de la asistencia que en él están obligados a hazer y tratándolo por procuradores les costaría, las más de las vezes, más de lo que vale lo que piden, que son de ordinario cosas menudas y sería perder muy gran preuilejio y preheminençia a la Inquisición.

24. El juez de bienes de esta Inquisición tiene quexa y la ha dado de las Inquisiciones de que, en las Juntas de Hazienda que se hazen cada vltimo día del mes, no se guarda con él y con el receptor lo que, por la Instruçion del año de 1560 está ordenado, la qual dispone que, en las dichas Juntas, los inquisidores confieran con el juez de bienes y receptor, ante el notario de secrestos, todo lo que ocurriere acerca de la aministraçión de la hazienda y pleytos que pendieren del fisco y lo que la mayor parte allí determinare, aquello se execute. Y que los inquisidores en las dichas Juntas se hazen solamente juezes y no permiten que, del voto del juez de bienes ni receptor, se haga quenta para las determinaciones de lo que se trata, ni tampoco sufren que, en las dichas Juntas, se trate y confiera cosa ninguna de lo que toca al empleo de los dineros que se dan a çenso y a la seguridad que en ellos sea de reçeuir, y las diligençias que acerca de ello se han de hazer, conforme a las dificultades que ocurriesen, siendo estas cosas en que, más que en otras algunas, consiste la buena o mala administración y conseruaçión de la hazienda. Y los inquisidores pretenden que esto es propio suyo y les toca particularmente y no puede ni se ha de entrometer en ello el juez de bienes, ni otra persona alguna. Y así, el orden que en ello tienen, es que, quando alguna persona pide dineros a çenso, presenta ante los inquisidores memorial de los bienes sobre que se ha de imponer y si determinan que se le dé, mandan hazer ynformaçión al notario de secuestros sobre el abono de los bienes, 
por thenor de vn interrogatorio que para ello ordena el abogado. Y vista en el Tribunal la ynformaçión, le dan o deniegan el dinero.

Pareçe que es justo que, en lo que toca a que los votos del juez de bienes y receptor hagan número y entren en quenta para la determinación de las cosas de la administración de la hazienda que se confieren y tratan en las dichas Juntas, se les guarde lo que la Instruçión ordena, pues tan claramente está dispuesto por ella. Y asimismo pareçe no sería yncombeniente que lo de los empleos de çensos se conferiese y tratase con los dichos juez de bienes y receptor, pues es cosa que toca a la administración de la hazienda y lo más importante de ella y en que por mucha seguridad que al tiempo del empleo se represente, se descubren de ordinario con el tiempo baxios e inconuenientes de que le resultan al fisco pleytos dificultosos y de mucha pesadumbre y quanto con más personas se tratare y comunicare al tiempo del ymponer el çenso más fácilmente se descubrirán las faltas que en el abono de los bienes huuiere y todo lo demás tocante a la seguridad mayormente que como el juez de bienes y receptor, casi comúnmente son naturales de este lugar, o de la comarca, tienen más particular notiçia de las personas y haciendas de ella y de muchas cosas encubiertas que en ellas suele hauer.

V.Sa IIma mandará lo que fuese seruido. Y también me pareçe deue V.S Ilma mandar al juez de bienes esté muy aduertido en no entrometerse en cosas fuera de su jurisdicción, ni en dar liçençias y mandamientos para redemir los çensos que ouieren redimirse, ni en hazer ynformaçiones, ni dar mandamientos de prisión contra personas que pretende le han hecho alguna ofensa a él o criados suyos, como lo ha hecho y haze algunas vezes. E ymporta cargarle en esto la mano, porque muestra demasiada afición a quererse authorizar y estender su jurisdicción a cosas bien agenas de ella y tiene poco respecto a los inquisidores.

25. Asimismo pretende el dicho juez de bienes que los inquisidores le hazen agrauio en que los mandamientos de execución que él da para el alguazil del Oficio, si açierta a estar ausente o inpedido, los inquisidores al pie del dicho mandamiento mandan que, por la ausencia o impedimento del alguacil, lo execute otra persona que ellos nombran y no permiten que el dicho juez, por impedimento del alguazil a quien va dirigido el mandamiento, nombre otra persona que lo execute. En esto no pareçe que pide cosa justa ni razonable, porque demás que por la Instruçión está dispuesto que, estando el alguazil impedido, el nombrar persona que en su lugar haga el ofiçio toca a los inquisidores y no a otro, en este caso particular de los mandamientos de execuçión que el juez de bienes da para executar cosas de la Hazienda, ay orden expresa dada por el Consejo por Carta receuida en xxii de septiembre del año de 157,9 por la qual se dispone que los mandamientos de execución se den al alguazil $y$, estando impedido, a la persona que por él nombraren los inquisidores. Y así, en esto no tiene que ver ni entrometerse el juez de bienes, lo que en este particular conuiene remediar, es que, por muchos mandamientos que el dicho juez de bienes ante mí ha presentado, pareçe que el nombramiento que los inquisidores hazen no está por la orden que debría, porque pone el inquisidor de su mano, en el 
mandamiento, execute este mandamiento fulano, sin que pase ante notarios ni escriuano ninguno, ni se haga con orden del tribunal.

Y así, conuiene que V.Sa Ilma mande que estos nombramientos no los hagan los inquisidores cada vno particularmente, sino por orden del Tribunal y ante uno de los notarios, para que se guarde lo que el Consejo tiene mandado y no se pueda pretender nulidad de la execuçión, por hauerse hecho el nombramiento sin la orden $\mathrm{y}$ forma deuida.

26. El scriuano del Juzgado acontece muchas vezes estar ausente del lugar quando algunos litigantes vienen de lugares de la Comarca a presentar peticiones en pleytos que tratan con el fisco y el juez, porque no se detengan y hagan gasto en negocios que ordinariamente son de poca importancia y de cosas menudas, reçiue las peticiones y haze los auctos ante algún otro scriuano que más a mano tiene y le nombra para ello. Y asi mismo pretende que, quando su scriunao tiene algún impedimento de enfermedad larga o muere y vaca el oficio, que el nombramiento de scriuano para su Juzgado, durante el impedimento o mientras V.Sa Ilma prouee el $^{\text {ma }}$ ofiçio, le toca a él. Y que así lo han hecho sus predeçesores en el oficio y él también lo hizo en la vltima vacaçión que ha hauido por muerte de Hernando Ruuiato. En esto los inquisidores le han ydo y van a la mano, pretendiendo que les toca a ellos el nombramiento y ansi en el que hizo en esta vltima vacaçión, mandaron al receptor no pagase el salario al scriuano que el dicho juez auía nombrado, ni se le pago hasta que V.Sa Ilma y el Consejo lo mandaron.

Y así, para atajar las discordias y diferençias que sobre esto cada día se puedan ofreçer, conuiene que V.Sa Ilma dé orden çierta de lo que se ha de hazer y pareçe se podría componer con que, en los casos que el ausencia y impedimiento fuese breue y de pocos días, se le permitiese al juez que para el buen espidiente de su Tribunal y para que no tuuiese cada hora de acudir al Tribunal para que le den scriuano, lo pudiese nombrar él y, en casos de impedimento largo conosçidamente o de vacaçión del oficio, le nombrasen los inquisidores. V.Sa Ilma mandará lo que más convenga.

27. La mayor quantidad de çensos que esta Inquisición tiene en Badajoz, Alburquerque, Valençia de Alcántara y su Comarca, son çensos heredados y confiscados, los quales, como desde el principio no se impusieron en fauor de la Inquisición, y los deudores no están obligados a los pagar o embiar a su costa a ella, ni sometidos al fuero del juez de bienes, todas las vezes que el alguazil los va a executar ay grandes pasiones y pesadumbres con ellos sobre las costas y salarios del camino si se han de lleuar, pues no están obligados a pagar fuera de sus propias casas, por que la orden que se tiene en dar estos mandamientos, es la misma que en los demás de execuçión, saluo que va añadido en cada vno de ellos que, si luego antes de la execución o próximamente después de ella pagaron lo que deuen no se les lleue salario de camino alguno, y sobre si es próximamente hecha la paga o no, ay grandes quexas y murmuraciones contra el Oficio, las quales pareçe podrían remediarse con que V.Sa Ilma diese liçençia y orden que estos çensos se redimiesen, que por la mayor parte son menudos y de poca quantidad y es hazienda de mucha pesadumbre y de poco prouecho para el fisco, y se entiende que cada uno de los çensatarios holgaría 
de los redemir si se los reduxesen a deudas líquidas y esperándoles por vno o dos años por ellas, que viene a ymportar poco a la Inquisición respecto de se deshacer de tan menuda y mala Hazienda. Y, aunque el año pasado de 1582, el juez de bienes, en la salida que hizo a cosas de la relaçion por mandado de V.S Il $^{\text {ma }}$ y del Consejo, hizo redemir algunas de estas partidas, fueron pocas, porque la comisión que tuuo fue de partidas muy menudas. Y conuendría, por lo que está referido, que se estendiese a todas las partidas de esta qualidad, o a lo menos a las que no subiesen de duzientos ducados arriua.

28. El alguazil de esta Inquisición, por Prouisión del Consejo, lleua de salario quatroçientos y çinquenta maravedíes en cada vn día de los que se ocupa quando sale a executar mandamientos de la audiencia del Juzgado de bienes donde no huuiere dezima y donde la huuiere la pueda lleuar, sin embargo de que, por las Leyes del Reyno, en las execuçiones de los maravedíes y hauer de Su Magestad, no se pueden lleuar más derechos de treinta al millar, so color de la qual Prouisión a aconteçido, y acontece algunas vezes, que los executores que, por ausencia o impedimento del alguazil propietario, se embían, lleuan enteramente el dicho salario por una parte y por otra la décima de algunas partidas que son gruesas y quantiosas. Y ay en esto confusión y mala orden, de que resulta nota e infamia a las cosas de la Inquisición y mucha pesadumbre con los deudores, porque el alguacil, si las partidas son menudas y le pareçe que sacará más vtilidad de lleuar el salario pide el salario y si de la décima, lleua la décima y algunas vezes, como dicho es lo vno y lo otro.

Pareçe que el remedio para quitar todos los incombenientes sería que al alguazil se le señalasen quinientos maravedíes de salario en cada vn día, el qual esté obligado a cobrarle de todas las personas que aquel día executare, repartiéndolo igualmente entre ellas y no cobrando de cada vno el salario entero, como se entiende que algunas vezes se ha hecho, cobrando con este fraude dos y tres salarios en vn mismo día. Y que, contentándose el alguazil con este salario, no lleue ni pueda lleuar dézima ninguna. A los menos conuiene mucho para quitar grandes pesadumbres que, de execuçiones menudas que fueren de diez mil maravedíes avaxo, no la lleue. Y que, lleuándola en las de diez mil arriua, salga a su riesgo y ventura por ella y no pueda en ninguna manera lleuar salario, porque acontece de ordinario que, después de hechas las execuçiones en vn lugar, se detiene en él esperando que pasen las 24 oras de la execución y si en ellas no pagan, lleua la décima y si dentro de ellas pagan, les lleua el salario que ellos no deuen de aquel día natural que se detuuo sin necesidad y sólo por su pretensión y prouecho. Y así se les hazen y lleuan demasiadas y exçesiuas costas.

29. El receptor embía a executar las deudas que le deuen dos o tres vezes al año, a lo qual sale el alguazil con los dichos 450 maravedíes de salario en cada vn día. Y con él va el mismo receptor, o otra persona con poder suyo, para cobrar y reçeuir los maravedíes que se le pagan y se va deteniendo en cada uno de los lugares donde se hazen las execuçiones, o en hazer quentas con los deudores, o en algunas prouanças $\mathrm{y}$ otras diligençias que tocan a su oficio de receptor, en lo qual se gastan y ocupan 
algunos días y de todos ellos lleua su salario el alguacil, no empleándose en cosas tocantes a la execución que ya él tiene hecha. De manera que, en cada vno de estos caminos que hazen, se detiene el alguazil vnas vezes quarenta días, otras çinquenta y algunas vezes más tiempo, según los negoçios y ocupaçiones que el receptor lleua, que viene a ser la mitad, o las dos terçias partes más de tiempo que es necesario y se ocuparía el alguazil si sólo se ocupase en hazer sus execuçiones. De donde resulta que se les lleuan y reparten a los deudores executados muchas más costas de las que real y verdaderamente se les deberían repartir, lo qual tiene necesidad de remedio

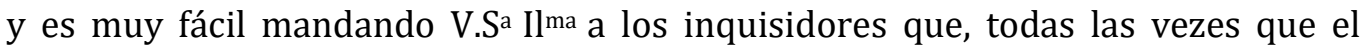
alguazil huuiere de salir a hazer semejantes caminos, le señalen y tasen los días que en las execuçiones se huuiere de ocupar conforme a los mandamientos, muchos o pocos, que lleuare y a la distancia de los lugares a dónde huuiere de salir. Y que de aquellos solos días que se le señalaren lleue salario y no de otro ninguno, lo qual se le mande que ansí lo guarde con muy graues penas.

30. Los abogados de los presos de esta Inquisición se quexan y se sienten muy agrauiados que los salarios que se les dan son tan cortos, que no solo no reçiuen vtilidad ninguna del oficio, pero resultales del muy notable daño y pérdida en sus negocios y hazienda, porque no se les da por cada causa en que aduogan después de feneçida y determinada, que a vezes suele durar tres y quatro años, más de seys reales. Y haziendo defensas, ocho. Y han de venir al Tribunal para cada vna de ellas muchas vezes y algunas a guardar fuera de él toda la audiencia y después boluerse sin efecto alguno, que les es de mucha pérdida, porque ninguno de los procuradores lleua menos a los que litigan en el Tribunal negoçios públicos de seys o quatro reales, por lo menos, de cada petición que presentan y a los aduogado,s al cauo de determinada vna causa, se les haze pago con esta miseria.

Pareçe podría V.Sa Ilma mandar que, de las causas de los que son ricos y tienen hazienda, se les pagase de salario diez o doze reales por cada vna, no siendo el reo menor, ni haziendo defensas y siéndolo o haziendola,s diez y seis, o diez y ocho reales. Y que siendo pobres y hauiéndose de pagar de la Hazienda del fisco, nueue reales, no siendo menor, ni haziendo defensas y doze reales, siéndolo o haziendolas. Y ansimismo que V.Sa Il ma mande a los inquisidores que en ninguno de los pleytos que se trataren en el Tribunal, así de familiares como otros qualquiera, reçiuan petiçion que no sea firmada de alguno de los abogados del Oficio, que de ordinario son los mejores letrados, porque demás que es mucha authoridad para el Tribunal y en esta Inquisición es cosa muy neçesaria, porque sacadas los aduogados de ella, los demás quasi todos son confesos muy notorios y descendientes de condenados y reconçiliados, les resultará a los del oficio alguna vtilidad con que se podrá suplir la tenuidad de los salarios que se les dan.

31. En muchos de los proçesos feneçidos y determinados de diez y doze años a esta parte, e hallado que las execuçiones de las sentencias en ellos pronunçiadas no están asentadas y queda el proceso muy ynperfecto y manco. Y en otras está, asentada alguna parte de la execuçion y faltan las demás. Y en muchas de reconciliados y penitenciados a galeras y a cárçel perpetua, no pareçe el entrego para las galeras, ni 
al alcaide de la cárçel, de lo qual, vltra de la ymperfection del proceso, resulta mucho inconueniente, porque quando V.S ${ }^{\text {Ilma }}$ o el Consejo pide los méritos, no se puede hazer relación çierta del cumplimiento de la penitencia y cosas contenidas en la sentencia. Y avnque la culpa de estos defectos pareçe que justamente podría cargarse al notario del Secreto que asiste a la pronunçiaçión de la sentencia y la asienta y da fee de ella, porque pareçe que a él le yncumbe y toca el cuydado de asentar también toda la execuçión de la dicha sentencia, pero, como muchas vezes la execuçión o parte de ella pasa ante otro notario y algún día o días después de la pronunçiaçión, los notarios en lo que no se halla asentado en los proçesos se disculpan todos diciendo cada vno que no pasó ante él. Y como esto no es posible aueriguarse, menos lo es castigarlo, y es cosa que tiene mucha necesidad de remedio. Este pareçe que podría ser mandando que, el notario ante quien pasare la pronunçiaçión de la sentencia, esté obligado a asistir también a la execución de ella y dar fee y asentarla en el proceso, poniéndolo en toda perfection, con aperçiuimiento que, todo lo que en la dicha razón se quedare en el proceso por asentar, sea a su culpa y cargo y sea castigado por ello, sin que se le admita por disculpa que no pasó ante él si ya no se descargare prouando que los inquisidores mandaron que la execución y algunos actos de ella pasasen ante otro notario. Y, en tal caso, sea obligado a pedir a los inquisidores que manden al notario ante quien pasó de fee y lo asiente en el proceso y hecha esta diligencia quede descargado y se cargue la culpa a los inquisidores, o al otro notario que, por la dicha diligencia, pareçeran hauer sido negligentes.

32. También en muchos de los dichos proçesos he hallado que algunas de las execuciones no a asistido ni asiste notario ninguno, sino que encargan a algún familiar, o al portero, o nuncio, que lleuen el reo a alguna iglesia a oyr una misa, o a hazer otra penitençia y después el notario asienta en el proceso que fulano, familiar o portero, refirió que auía oydo la misa, o cumplido la penitencia que se le mandó, lo qual es muy mala orden y peligroso, de que algunas vezes se dexe de hazer y cumplir la penitencia ympuesta. Y es negocio que no puede el notario fiarlo de otro y en que de necesidad a de asistir él para poder dar fee del cumplimiento. Y avn conuiene que, en todos los casos que se pueden poner testimonios, los ponga para que el aucto tenga entera fee, lo qual no se haze, ni tampoco quando alguno se entrega para galeras, o en la cárçel perpetua, se haze firmar el aucto del entrego del alcaide de la cárçel, o de la persona que lo reçiue, lo qual se requiere para perfeçión de él.

Y asi conuiene que V.S Ilma mande que, en todo esto, se guarde el Derecho y buen estilo de la Inquisición y que, a todas las executiones, asista y de fee de ellas uno de los notarios del Secreto, poniendo testigos en todos los auctos que lo sufrieren y los pudiere hauer. Y que todos los entregos que se hizieren de algún reo, o reos, para galeras, o cárçel perpetua, o otras partes, los firme de su nombre la persona que los reçeuiere sauiendo scriuir y no sauiendo, dé de ello fee el notario.

33. La raçión que se da a los presos para alimentos, es tan tasada que ymporta muchísimo tener gran cuydado que se les dé caual y de buenos mantenimientos y a 
los preçios más acomodados que corren conforme a la temporada, por que, en qualquiera de estas cosas que aya falta, padecen muy notablemente los presos. El remedio que pareçe muy conueniente para que esto vaya puesto siempre en razón, es que se mande muy estrechamente a los inquisidores que, tres o quatro vezes por lo menos cada mes, cada vno por su turno, quando más seguro y descuidado estuuiese el despensero, o proueedor de los presos, vaya a la despensa y por ante vno de los notarios del secreto, informado primero con cuydado de los preçios a que valen en la sazón los mantenimientos, los visite y vea sauiendo a qué preçios se dan a los presos y si son de la qualidad y bondad que conuiene y los pesos y medidas cauales y en lo que hallare fraude o falta lo refiera luego en el Tribunal, el qual lo castigue con mucho rigor porque de no hauer hecho en esto diligencia los inquisidores ni curadose de visitar jamás la despensa ha haudio acerca de ellos muchos inconuenientes y quexas de los presos que lo padecen y no tienen a quien acudir si los inquisidores no lo remedian.

34. En la prouisión del trigo que se compra para los dichos presos y quentas de panadero no ay la buena razón y claridad que conuendría, antes mucha confusión y embaraço, no sin peligro de la conçiençia de los que lo tratan y con mucho daño de los presos. La principal ocasión de esto naçe de que el dicho trigo se va comprando y proueyendo poco a poco por cayzes y hanegas y como se compra en diferentes tiempos, así lo son también los preçios vnas vezes vaxos, otras vezes más subidos y al respecto a los presos se les dan las libras que cada día han de comer, vnas vezes a ocho maravedíes, otras a diez, otras a seys, según cómo es el valor del trigo y con tanta mudança puede hauer poca claridad en las quentas del panadero y los presos comen el pan muchas vezes al doble más caro de lo que lo podrían comer si huuiese la orden que conuiene.

Esta pareçe que sería que, pues el receptor es el que lo a de probeher, que como se va comprando poco a poco y por todos los tiempos del año, los inquisidores, al tiempo de la cosecha y quando más varato vale hechando la quenta del pan, que en todo el año hasta la cosecha siguiente se podrá gastar conforme a los presos que huuiere, o pudiere hauer según la dispusiçión de los negocios, manden al receptor le prouea con la mejor comodidad que le pudiere hallar, empleando en esto el dinero que menester fuere de quales quier maravedíes de su cargo. Y este trigo se ponga en algún aposento acomodado y seguro y hecha la prouisión se conçierte el receptor con el panadero o panadera que mejor pan y más libras diere, haziendo el tanteo con vna o dos hanegas de las libras que por cada vna se pueda y deua dar, con que sea bueno y bien masado y coçido. Y que este conçierto sea firme e ygual para todo el año y conforme a él se asiente el preçio a que, en todo aquel año, han de comer el pan los presos y con esto abrá mucha claridad en las quentas del panadero y los presos comerán todo el año el pan igualmente bueno y a vn mismo preçio, y este el más baxo y acomodado que podrá ser en todo el año, comprándose el trigo todo en el tiempo de más comodidad y barato, y les quedará bastante raçion para las demás que huuieren menester. Lo que a sido tan al reués en algunos de los años pasados, por no hauer hauido en esto la orden que conuenía, que no les sobraua a los presos 
casi ninguna cosa de raçión, pagado el pan. Y todo el dinero que el receptor huuiere gastado para los presos que son ricos y comen de su hazienda, lo yrá cobrando del probehedor de las libranças que para sus alimentos se le dieren, sin que reçiua daño el fisco ni su hazienda. Y admitirse le ha al receptor que, en ninguna manera, permita que una misma persona haga oficio de panadero y proveedor, por que por la experiencia se a visto muy claramente que de ello resultan muy grandes inconuenientes en daño de los presos.

35. En el dar libranças para el receptor para alimentos de presos como pobres pareçe que ha hauido mucha facilidad y no el cuydado que conuenía, porque ha algunos presos se les han dado alimentos a quenta del fisco que a parecido tenían hazienda ellos, o sus padres, o personas que tenían obligación de los sustentar para poderlos alimentar. Espeçialmente pareçe que vn Pero Gutiérrez, estudiante, vezino de Montanches, que ha estado mucho tiempo preso, tiene padre rico y scriuano público que gana muy bien en su oficio y se trata honradamente y ha comido todo el tiempo de la hazienda del fisco. Y asimismo vn Gabriel de Torres, vezino de La Parra, que después de larga prisión y hauer en toda ella comido a costa del fisco, a sido penitenciado en pena pecuniaria de quarenta ducados y si este hera persona de qualidad y hazienda que pudo ser condenado en esta pena, muy más deuidos le son al fisco los alimentos que ha comido, que no ella.

Para remedio de estos y semejantes yncombenientes, pareçe que V.S Il $^{\text {ma }}$ deue mandar que los inquisidores no puedan dar libranças para presos pobres, sino es constando, por euidente notoriedad, que lo son como gente soltera y vagamunda, o preçediendo legítima y bastante ynformaçión de que, ni ellos ni sus padres, ni otras personas, que estén obligadas a sustentallos, tienen hazienda para los poder alimentar. Y que, de esta información, conste por fe de vno de los notarios en el Libro donde los dichos libramientos se registran y que lo que de otra manera se librare, lo paguen los inquisidores de su hazienda.

36. Los libros que conforme a Instruçiones han de tener el alcaide de las cárçeles secretas, notario de secrestos y despensero de las entradas de los presos y gasto de ellos, no se han traído, ni traen con la orden y claridad que conuiene y por las dichas Instruçiones está ordenado, porque en el Libro del alcaide solamente se asienta el día de la entrada del preso y lo que consigo trahe y la raçión que se le señala, estando mandado por las Instruçiones que, demás de esto, en el dicho libro se ponga la hora de la entrada del preso y todo lo que va gastando, así en la raçión ordinaria, como en extraordinarios por visitas de los inquisidores y reçeptas del médico, y asimismo que se asiente el día y ora que el reo sale y la ropa que saca de la cárçel, o queda en ella, para que en todo aya claridad y buena quenta y razón. Los Libros del despensero y del notario están sin orden alguno mezclado y revuelto el gasto con el reçiuo con mucha confusión, estando ordenado por las Instruçiones que estos libros se traygan como libros de caxa por deue y ha de hauer poniendo en la vna plana el día y ora que el preso entra y la raçión que se le señala y lo que trahe consigo de ropa y dinero y todo lo demás que se ba librando, o en el receptor si es preso pobre, o en el depositario del secreto si tiene hazienda. Y asi mismo, el día que sale y lo que lleua 
y en la otra plana todo lo que va gastando en ordinario y extraordinarios, para que todos estos tres libros vayan siempre conformes y con toda claridad y se pueda ver, siempre que conuenga, la quenta líquida de cada vno.

El no hauerse guardado esta orden como conuenía ha nasçido de no sauer cada uno de estos ofiçiales lo que acerca de esto a de hazer, ni tener la notiçia que están obligados de las Instruçiones que a su oficio tocan. Y así para remedio de esto sea asentado por el secretario de esta visita en el principio de cada vno de los dichos libros toda la orden que conforme a Ynstruçiones y Visitas pasadas y lo que más de nueuo ha parecido añadir cada vno de los dichos oficiales, está obligado a guardar y se les ha notificado la cumplan y guarden y puesta la notificaçion en los dichos libros y en el Libro de las Instruçiones, para que no puedan alegar ni pretender ynorancia. Y queda ordenado y mandado a los inquisidores que lo mismo se haga para adelante con cada vno de los ofiçiales que de nueuo se requieren a alguno de los dichos oficiales. V.Sa Ilma si fuere seruido podrá mandar que esto así se guarde y cumpla.

37. Andando viendo con cuydado las quentas del gasto de los presos, he aduertido que a ninguno de ellos, avnque sean ricos y coman de su hazienda, se les quenta cosa ninguna de lo que el médico reçepta en la botica para sus enfermedades, sino que todo se paga a quenta del fisco. Y queriendo sauer la ocasión de esto, me dizen que se ha hecho y haze para que no se entienda en la votica quien son los que están presos en las cárçeles secretas y por esto en las reçeptas no se pone nombre ninguno, solamente se dize para la Inquisición y así después a la quenta, como no se saue particularmente quien gastó las medicinas, sino en general a nombre de Inquisición, se libra toda la quenta del boticario en el receptor y lo paga el fisco.

Esto pareçe que no es justo pase adelante, ni que la Hazienda reçiua este daño, mayormente siendo como es tan façil de remediar el incombeniente que hasta agora en estos se ha hallado. Y para remedio de ello quedó mandado que, de aquí adelante, en todas las reçeptas que el médico ordenare para pobres o para ricos se les ponga algún nombre, el qual sea nombre disfraçado y desconocido de cosas que no sean nombres de persona y este nombre que se pusiese a qualquier preso para la votica le asiente luego el alcaide en su libro en la margen de la hoja donde está asentado el nombre de aquel preso diciendo este en la votica se llama fulano y lo mismo hagan el despensero y notario de secrestos cada vno en su libro y quando se tomare la quenta al boticario, se haga de por sí a cada vno de los presos por sus reçeptas y lo que le cupiere, tasado por el médico, lo asienten a su quenta en sus libros el alcaide, despensero y notario, quedando las reçeptas, pasada la quenta, en poder del notario de secrestos, el qual las ponga por su orden en el aposento de sus papeles. Y lo que fuere de presos ricos se cobre de su hazienda, dando de ello mandamiento al despensero para los depositarios de los secrestos y cobrado de ellos lo pague al boticario tomando de él cartas de pago debaxo de los mismos nombres disfraçados que han tenido los presos en la votica, para que no entienda el boticario quien son. Y lo de los pobres solamente se libre en el receptor, so pena que, lo que de aquí delante, de reçeptas de presos ricos se librase en el receptor y se pagare de la 
Hazienda del fisco, lo pagarán los inquisidores de la suya. Esto queda así ordenado hasta que V.S IIma mande otra cosa.

38. En muchos proçesos feneçidos de penitenciados y reconciliados he aduertido que, hauiendose por Prouisión de V.S ${ }^{\text {a }}{ }^{\text {ma }}$ o del Consejo, sacado los méritos de ellos y embiado, no pareçe en el proceso la Prouisión en cuya virtud se sacaron y en algunos no queda borrador, ni original de los méritos que se sacan y,en los que quedan, no ay firma ni señal de ninguno de los inquisidores, ni de notario, ni tanpoco se asienta si se han embiado al Consejo, ni quándo. Y en muchos, hauiendose mandado comutar a los reos los hábitos y carçelerías en otras penitencias, no pareçe por los proçesos razgón de lo que en ello se ha hecho. Todo lo qual, es gran manquedad e ymperfection de los proçesos y muy grande inconueniente para la claridad de los negocios y certeza y buena orden que ha de hauer en los de la Inquisición, para que por el proceso se pueda ver todo lo que en él ha pasado.

Y así queda mandando a los inquisidores y notarios, mientras V.Sa Ilma no ordena otra cosas que, siempre que por prouisiones de V.Sa Ilma 0 del Consejo se sacasen méritos de algún proceso, se cosa en él la Prouisión en cuya virtud se sacan, con día, mes y año de ls Prousión y al tiempo que se embiaren quede siempre en el proceso el original de los dichos méritos que se sacaren, firmado o señalado por los inquisidores que residieren y el notario que los despachare asiente en el fin del dicho original el día que se embiaron al Consejo. Y así mismo, quando se presentare alguna Prouisión para comutaçión de algún hábito y carçelería en otras penitencias, se cosa originalmente en el proceso todo lo que por virtud de ella se hiziese con el reo.

39. Lo que en esta Inquisiçión se ha hecho y haze que a los reos que no sauen scriuir sus defensas se les a permitido y permite que el notario de secrestos o vno de los del Secreto trate y comunique con ellos a solas en vna de las salas de la audiencia y vea el trasladado de la publicación que se le ha dado y le ordene y scriua sus defensas, es de mucho inconueniente y directamente contra la Instrucción por la qual se prohiue que ninguna persona, avnque sea el inquisidor, pueda tratar ni comunicar a solas con el reo en ninguna manera, saluo el alcaide a quien solamente se permite.

Y así queda mandado a los inquisidores, hasta tanto que V.S ${ }^{\text {a }}{ }^{\text {ma }}$ otra cosa ordene, que de aquí adelante no se de lugar a que ni notario del Secreto, ni de secrestos, ni otro oficial, ni persona algun,a trate ni comunique con ningún reo preso a solas, sino el alcaide y si el reo a quien se diere publicación y quisiere hazer defensas dixere que no saue screuir, llámese su letrado a la audiencia y trayendo a ella el reo, en presencia del inquisidor y notario del Secreto, ynforme a su letrado de todo lo que quisiere para su defensa, el qual allí en papel que para ello se le dé rubricado del notario scriua todos los apuntamientos que el reo dixere para sus defensas y los lleue a su casa para ordenarlas y quadno las truxere buelua todos los pliegos de papel que huuiere lleuado contados y rubricados juntamente con el traslado de la publicación si le ouiere lleuado y lo entregue todo al notario del Secreto en el Tribunal en presencia del inquisidor sin que en su poder quede cosa alguna, como lo manda la Instruçión. 
40. Ansimismo lo que en esta Inquisición se vsa que para hazer audiencia con vn reo asisten de ordinario los tres inquisidores, o los dos juntos, demás que es contra lo que en todas las otras Inquisiciones se acostumbra, es en muy gran daño de la expedición de los negocios y causa mucha dilaçión en ellos, porque se ocupan tres inquisidores, o dos, en lo que puede y ha de hazer vno solo y ordinariamente lo hará mejor, porque los que asisten más le embaraçan por no dexarle con liuertad que le ayudan y en el mismo tiempo que se haze aduiencia con vn reo, se puede hazer con dos otres, o despacharse otras cosas que importan.

Ase ordenado a los inquisidores, entre tanto que V.S Ilma $^{\text {ma }}$ otra cosa manda, que, de aquí adelante, las audiencias ordinarias con los reos, las haga vn solo inquisidor, el que más instructo estuuiere en el negocio y los demás hagan otras audiencias, o saquen publicaciones o acudan a otras cosas que se ofreçieren, saluo si fuere algún negoçio muy graue y de dificultad que parezca conuiene asistan todos los inquisidores o los dos de ellos, que en este caso que pocas vezes acontecerá, será bien se haga lo que pareçiere conuenir. Y también quando algún inquisidor nueuo viniere, que no tenga notiçia de las cosas de Inquisición, ni del estilo y modo de proceder en ella, conuendrá que algunos meses asista con el colega o colegas para instruirse en ello. Pero fuera de esto, conuiene que lo haga vn inquisidor sólo para que los negoçios corran y aya la deuida expedición en ellos.

41. A algunos de los reconciliados que están condenados a hábito y carçelería en la casa de la penitencia, o cárçel perpetua, han acostumbrado, de mucho atrás, los inquisidores de esta Inquisiçión dar liçençia, o permitirles que biuan con el hábito en casas propias de sus moradas, con que todos los domingos y fiestas acudan a la cárçel perpetua y de allí con los demás penitentes vayan con el alcaide a la iglesia mayor. Y de esta manera hay oy en esta villa tres reconçiliados, el vno mesonero y los dos çapateros. Esto por vna parte pareçe de algún yncombeniente, porque no asistiendo en la casa de la cárçel perpetua, no se puede tener certidumbre de cómo cumplen sus penitencias. Por otra parte, es también de consideración que, teniendo oficiales que no pueden exerçitarlos en la casa de la penitencia, se les quite del todo la forma de poder biuir y sustentar su muger e hijos y también que, teniendo muger e hijas doncellas, no pueden sin peligro biuir entre tantos penitenciados y dexandolas en otra casa todas las noches solas también es cosa peligrosa. Y pues todos los domingos y fiestas acuden con los demás penitentes a la iglesia, pareçe que se cumple con lo que más ymporta de la penitencia y solamente difiere de los demás en que las noches no se recogen en la casa de la cárçel perpetua porque los días, ansí los vnos como los otros, andan por donde quieren buscando su vida.

Por estas razones, no he querido alterar cosa ninguna, ni mandar a estos tres que biuen en sus moradas que se recogiesen a la cárçel perpetua por concurrir en ellos todas las qualidades referidas, sino dar quenta de ello a V.S Il $^{\text {ma }}$ para que mande lo que sea seruido y pareçe se podría ordenar a los inquisidores no diesen de aquí adelante semejantes liçençias sin orden de V.Sa Ilma o del Consejo o a lo menos que fuesen muy raras vezes y en caso de muy preçisa y vrgente neçesidad. 
42. Los asientos que los inquisidores y oficíales tienen en la Yglesia mayor quando ban a ella a asistir a los oficios, no han estado con la authoridad y decentia que conuenía, ni han tenido forma çierta, antes los inquisidores por su particular pareçer los han ydo trocando y mudando y en diferentes maneras y de todas ellas han resultado inconuenietnes y quexas entre los inquisidores y oficiales. $Y$ han venido algunos de ellos a no querer acompañarlos, por pretender se les haze agrauio en el lugar que se les señala y que el Oficio no está con la authoridad y desçençia que conuiene, ni con comodidad paa poder oyr los ofiçios y sermón, hauiedno de boluer al tiempo de él los propios inquisidores sus sillas con mucha descompostura, y acauado tornarlas a boluer al altar. He mirado por vista de ojos la dispusiçión del sitio y, conforme a él, platicado con los inquisidores y con el prouisor y curas que en esto pareçe podrían tener voto, queda en conformidad de todos dada traça çierta y perpetua, por la qual están los asientos de los inquisidores con toda la authoridad y desçençia que conuiene y comodiad para oyr los oficios y sermón sin hauer de hazer ninguna mudança y los de los ofiçiales consecutiuamente por la orden que cada vno en el Oficio tiene sin que pueda pretender agrauio ni perjuicio alguno y queden todos en choro çerrado en la capilla mayor a la parte del Ebangelio, sin que persona alguna pueda entrar allí a dar inquietud ni pesadumbre, como antes solía, para que esta orden y conçierto quede perpetuamente asentado, será V.Sa Ilma seruido mandar que no puedan los inquisidores, particularmente ni el Tribunal, sin expresa liçençia de V.S ${ }^{\text {a }}{ }^{\text {ma }}$ o del Consejo, mudar ni alterar esta forma de asientos y que al mismo respecto se guarde en las otras yglesias donde se asistiese con forma de Oficio.

44 [sic.]. En las casas de la Inquisición vieja, donde agora se a pasado el Oficio, no ay aposento ni lugar ninguno para audiencia del Juzgado de bienes, ni para poner los papeles de él, ni tanpoco los del oficio de notario de secuestros. Y así, a sido forçado por la necesidad tomar vna casilla arrimada a la Inquisición donde, como de prestado, se han puesto. V.S I Ima será seruido mandar dar en esto la orden que conuiene para que estos papeles, que son todos los que tocan a la Hazienda, estén con la buena orden y seguridad que conuiene.

44. Asimismo falta cárçel de familiares y es muy neçesaria, porque como el distrito es tan grande y ay en él muchos, siempre han de estar algunos presos. Pareçe que podría V.Sa Ilma mandar que ésta se traçase en el lugar que paresçiese conueniente y se juzgase por alarifes lo que abría de costas y esto repartido entre todos los familiares del distrito para quien ha de seruir, como en algunas otras partes se a hecho. Y como los familiares son tantos, les cabría a muy poco a cada vno y tendrían cárçel buena y acomodada. Y también será V.Sa Ilma seruido declarar a cuyo cargo a de estar la guarda y custodia de la cárçel de los familiares, porque el alcaide de las cárçeles secretas puede mal acudir a esto y así se excusa de hazerlo mayormente sin ningún salario. Pareçe se podría esto encargar al nuncio o portero con algún moderado salario. V.Sa Ilma mandará lo que más fuere seruido. = El Doctor Luis de Copones. $=$

[AHN, Inquisición, leg. 1989, exp. 11, ff. 4r-17r] 
IV.5. Advertencias que resultaron de la visita que se hizo en la inquisición de Llerena en 1620

Advertencias que resultaron de la Visita que se hizo en la Inquisición de Llerena el año de 1620. Mandadas guardar por el IImo Sr Inquisidor General, confesor de Su Magestad y Señores del Consejo de Inquisición.

1. Que aya libro de testificados donde se asienten por las letras del A.B.C. los que se mandaren llamar y prender.

2. Que se vean y recorran todas las visitas del distrito desde el año de 1600 y las testificaciones que hubiere desde el dicho año y que se execute lo que cerca de ellas no lo estuviere.

3. Ítem que se despachen las comisiones de las diligencias que se mandan hacer luego sin dilación, porque de dilatarse se suelen perder los negocios de fee y otros de consideración = Y para que no haya descuido, se manda que el notario del secreto ante quien pasaren los decretos o al que cometieren el despacho, eche su rubrica y señalai para que se sepa a quien se encomendó y que este despache luego las comisiones o cartas para que se hagan las diligencias y que, no lo cumpliendo, dentro de dos días, sin nuevo avisto, incurra en pena de cuatro reles por cada falta que hiciese y se le descuenten de su salario. = y que se haga un libro en el cual se ponga por el notario en relación las prouiciones letras comisiones, cartas y otros despachos que se hicieren poniendo el dia, mes y año y la sustancia del negocio y a qué comisario se despachó, para que se vea si el comisario lo remitió y habiéndole remitido se ponga en la margen de cada despacho el recibo. Y dilatándose la respuesta, el mismo notario del secreto cuide de que se vuelva a escribir y el fiscal hacer recuerdo si el tal notario tuviere descuido para que se vuelva a escribir al comisario. Y que el notario que faltare en poner la dicha relación ende dicho libro, pague, cada vez, cuatro reles y se le descuenten de su salario. Y que el fiscal haga memoria de las faltas y penas en que incurrieren y las refiera a los inqusidiroes al tiempo de la paga del tercio para que provean al receptor que se las descuente. Y que los inqusidiorss hagan executar y ejecuten todo lo contenido en este capitulo. Y que el fiscal habiendo falta en ello dé cuenta al Consejo para que se averiguen los descuidos y faltas que hubiere.

4. Ítem que en la relación de causas despachadas que cada año se envía al Consejo, se envie relación aparte de las testificaciones que aquel año huviere habido, ansi en cosas de fe, como en procesos y causas de comisarios y familiares y notarios, con claridad de lo que en cada uno de ellos se hubiere hecho y del estado que quedan.

5. Íten que, en los procesos y causas criminales contra comisarios familiares y notarios que están pendientes, se notifique a las partes que las prosigan si quisieren. Y si no las siguieren, vean los inquisidores los que son de calidad de poder los seguir el fiscal y ordenen que los siga y den cuenta al Consejo de lo que en esto se hiciere.

6. Íten para que se sepa facilmente las personas que están notadas y testificadas, ansi en los registros del Santo oficio, visitas y cuadernos y procesos de él y en otras cualesquier escrituras del secreto, se haga un repertorio general de todos ellos que comprenda de veinte años a esta parte y se vaya continuando, porque haciéndose asi, no podrá quedar 
testificación sin sacasrse a luz y de que no se pueda aprovechar el fiscal contra las personas notadas.

7. Iten todos los votos de captura y de difinitiva en causas de fee se pongan originales en el Libro de votos y allí los publiquen los inquisidores y los de definitiva inquisidores, ordinario y consultores. Y de allí se saque copia autentica a los procesos, sin que en manera alguna se pongan originales en ellos.

8. Iten en las causas criminales de familiares y ministros, los votos de captura y de sentencia definitiva sean de poner en otro libro y de allí se han de sacar a los procesos. Y la sentencia defintiva se hara conforme al tenor del autor. Y si los inquisidores fueren discordes y motivaren, no se han de sacar mas de los votos de la mayor parte sin motivos, porque tiene muchos inconvenientes sepan las partes de la discordia y motivos de los inquisidores. Y habiendo de ir el proceso al Consejo, se sacarán los votos de los inquisidores a la letra con sus motivos. Y lo mismo se guardará en cualquier aucto interlocutorio en que hubiere discordia de votos y motivos, asi en casusas criminales como civiles de las que conoce el Tribunal y de provisiones de memoriales, o peticiones, que a las partes no se les a de hacer notoria la discordia, sino solo el Decreto de la mayor parte.

9. Ítem que las provisiones de oficios de gracia se hagan concurriendo todos los inquisidores que no estuvieren ausentes de ausencia larga. Y el que no fuere admitido por alguna causa no pueda después ser admitido, sino es concurriendo en su provision todos los inquisiores que se lo denegaron, no habiéndose mudado o muerto el inquisidor que no vino en ello. Y que todas las peticiones que presentaren los pretendientes a quienes no se dieren los tales oficios, se guarden en legajo aparte, poniendo en ellas como se les denegó, sin expresar causa y si se les deniega algunos, en concurrencia de otros a quien se proveyó el tal oficio, se ponga en las peticiones de los que se dio esta familiatura u oficio a fulano.

10. Ítem que el inquisidor que saliere a la visita no nombre familiares comisarios ni otros, sino que si le pidieren algo en razón de estos oficios envíe relación al Tribunal de las personas que le parecieren más a propósito para los tales oficios y se haga lo que el Tribunal acordare, teniendo consideración a lo que el inquisidor visitador aprobare. Y que la Comision para hacer las informaciones la despache el tribunal.

11. Íten que asista un inquisidor al examen de los testigos que se recibieren en el Tribunal, ansi de causas criminales de familaires, como de informaciones de genealogías, y al recibir la confesión y declaración del reo, pues es acto judicial y no se debe fiar de notario cosa de tanto prejuicio. Y se encarga sobre esto la conciencia a los inquisidores, para que ansi lo hagan y cumplan.

12. Ítem se ordena que ningún inquisidor en particular pueda prender a ninguna persona por ningún caso de cualquier calidad que sea, sin que todos traten de ello y lo confieran y conformes, habiendo precedido información, lo manden prender y preso soltar. Y, si el caso toca a algún inquisidor, o a sus criados, no tenga voto en el tal caso, ni asista al tratar de ello, porque sus colegas con libertad provean lo que convenga y por que muy de ordinario, creyendo las quejas que dan sus criados de los que venden mantenimientos de que no les dan lo que piden, sin mas averiguación de la verdad, los 
prenden y hacen padecer en cárcel algunos días. Se ordena, ansi mismo, que no los puedan mandar prender sin que preceda información y que concurran en estas prisiones los votos y pareceres de todos como queda referido y no siendo causa de fee no pongan en cárceles secretas a ningún preso, que es exceso digno de gran castigo. Lo cual anssi se cumpla, so pena de excomunión y de viente ducados por cada vez que contraviniesen los inquisidores. Y el fiscal dará aviso al Consejo todas las veces que contravinieren a lo dispeusto en este capítulo, para que se execute la pena y se provea de mas fuerte y eficaz remedio.

13. Ítem que las relaciones las dicte el inquisidor mas antiguo, no estando impedido, y las publicaciones las escriban o dicten uno de los inqusidiores. Y las proposiciones las saque uno de los inquisidores y se califiquen en el Tribunal, firmando las calificaciones los calificadores; y el fiscal no se entrometa en sacarlas, ni los notarios las relaciones de procesos de fee, ni publicaciones, sino solo escribirlas, dictándolas los inquisidores. Y el fiscal, sino se hiciere, dará cuanta al Consejo.

14. Ítem se ordena que haya un Libro registro donde se escriban, continúen y registren los consultores, calificadores, abogados, comisarios, notarios y familaires y otros ministros de la Inquisición, poniendo el día, mes y año y los inqusidores que los prebeyeron. El lugar para donde son admitidos y por muerte de quién y de cómo se les recibió y el juramento de fidelidad y secreto acostumbrado y se les despachó el titulo por tal notario, poniendo el que se halló presente a la creación y juramento del tal ministro y en las informaciones, cómo fueron admitidos y criados y juraron y en qué audiencia y ante qué inquisidores y de que hizo el juramento de fidelidad acostumbrado, todo estendido dando fee de ello el notario ante quien pasare. Por que es mucho defecto poner solo en membrete fue admitido y juro. Y se manda que los notarios del Secreto lo cumplan y guarden en la dicha forma, sin que en ello haya descuido. Y abiendole lo castiguen los inquisidores, penando al que contraviniere, cada vez en cuatro reales, que se les descuente de su salario.

15. Ítem que, en los negocios públicos civiles y criminales, se provea por el más antiguo que se hallare presente abiertas las puertas; y si no se conformaren se reserve para tomar resolución a solas después de las tres oras que están en el Tribunal, entrando los procuradores y las partes al ver y proveer sus peticiones. Y que en los despachos que se hacen, se pongan los derechos que el notario del Secreto lleva. Y cuando se vote algún pleito publico en difinitiva, o sobre alguno artículo, se citen las partes para que se hallen al ver el tal negocio, y se le dé luego noticia de todo lo que se provee, sin retardarles el despacho de estos negocios.

16. Ítem que se guarde la carta del Consejo, de 20 de mayo de 1610, en razón de las visitas que an de hacer los inquisidores.

17. Ítem que el inquisidor más antiguo ordene que, en vacaciones o fiestas, si se ausentare alguno notario del Secreto, no falte uno siempre para lo que se ofreciere.

18. Ítem que, en muchas cartas del Consejo que se remiten con los procesos, se suelen dar órdenes de lo que se debe guardar en casos que se ofrecen semejantes y las cosen originales en los procesos, de que se siguen inconvenientes, por no se tener noticia de ellas. Se ordena que se copien y pongan en el proceso y las cartas originales se cosan en 
el Cuaderno de cartas del Consejo. Y cuando se hace alguna conmutación de penas y penitencias por el Sr. Inquisidor General y Consejo, se ponga la razón en el proceso y cómo se executó. Y si fue de dinero, a quién se dio y entregó, porque, de no lo cumplir ansí, falta muchas veces claridad de lo que tanto importa.

19. Ítem los presos de cárceles de familiares y comunes no oyen misa las fiestas y en esto ha habido mucha falta. Y ansí se ordena que la oigan todos los días de fiesta en la sala del Tribunal, donde asista con ellos el alcaide, que de ordinario suele haber misa las fiestas para el inquisidor que vive dentro de la inquisición. Y quando no la hubiere, los presos paguen la limosna de la misa; $y$, si fueren pobres, uno de los capellanes la diga y el alcaide cuide de esto, de suerte que no se queden los presos sin missa; y los inquisidores tengan cuidado de saber si se cumple y de castigar al alcaide si en esto hubiere descuido. Lo cual se cumpla si el delicto de cada uno diere lugar a ello.

20. Ítem se ordena que en el Libro del alcaide donde se asientan los presos que vienen a las cárceles, se asiente el día y ora que entra el preso en la cárcel y la ropa que trae, con toda distinción, y el día que sale de la cárcel y la entrega de la ropa y la que queda, para hacer de ella cargo al receptor, y la ración que se le señala, lo cual ha de asentar uno de los notarios del Secreto y la entrega de la ropa o la que queda; $y$ todo lo que gasta cada mes por mayor ordinario y extraordinario por partidas y receptas de medicinas, ha de asentar en el dicho libro con toda claridad y distinción, con el día, mes y año, y los inquisidores tengan cuidado de ver el dicho libro y si hubiere falta lo castiguen.

21. Ítem el notario de secrestos ha de tener otro libro que vaya en la misma forma que el del alcaide, asentando el día y ora que entra el preso y el dinero y ropa que trae consigo y la ración que se le señalare y el día que sale de las cárceles y la hora y la ropa que se le restituye, o se queda, para que se haga cargo al receptor; y en una plana se ha de poner lo que se libra y en otra el gasto; y los inquisidores tengan cuidado de reconocer este libro y ver si se guarda el dicho orden y si hubiere falta la castiguen.

22. Ítem al fin de cada mes se ha de tomar la cuenta al despensero por el notario de secrestos, con asistencia de uno de los inquisidores, alcaide y receptor y la cuenta y alcance se hará con los cuadernos del gasto del despensero y el Libro del notario de secrestos se rematara así mismo y se firmará por el notario y despensero; y los recaudos del despensero, que diere para pagarle los gastos extraordinarios de botica, medico, prouisión de visita, los pondrá el notario de secrestos por orden de cada año en el aposento de sus papeles, de suerte que se hallen si en algún tiempo fueren menester; y cuando sale el preso de la cárcel, se junten a hacer la cuenta los suso dichos y se le lea todo lo que hubiere gastado, ansí de raciones, como de gastos extraordianrios y que declare si se le ha dado y gastado y se satisfaga del gasto y recibo y que va lo que le alcanzan o alcanza del dinero que se entrego de su Hacienda; y aunque sea pobre conuyene que tenga presencia se haga la cuenta, para que se sepa si se le ha dado toda la ración y que si ha ahorrado algo de ella se le entregue; y se encarga a los inquisidores la conçiencia que hagan cumplir todo lo contenido en este capítulo con puntualidad.

23. Ítem se ordena que el Juez de bienes acuda a su Tribunal a tener audiencia cada día a las dos de la tarde, para que, bajando los procuradores de presentar peticiones en el Tribunal ante los Inquisidores, acudan a la audiencia del Juzgado. Y no pueda hacer 
ausencia de la villa en días de audiencia sin licencia del tribunal, so pena de incurrir en las penas establecidas contra los ministros asalariados del Santo oficio que hacen ausencias sin licencia. Y no lleve derechos algunos de autos, ni sentencias, ni otra cosa que proveyere como tal Juez de Bienes mas que los del arancel, pues lleva salario y está prohibido por Instrucciones del Santo Oficio a los oficiales asalariados de él no lleven derechos algunos; y si el dicho Juez los llevare, incurra en las penas impuestas contra los tales en las Instrucciones y Cartas Acordadas. Y no nombre substituto sin aprobación del Tribunal. Y los inquiaidores tengan particular cuidado de que ansí se cumpla lo contenido en este capítulo, y no lo cumpliendo el Juez de bienes y hauiendo algunas quejas de no despachar con diligencia los negocios, darán aviso al Consejo para que se ejecuten las penas y se ponga el remedio necesario y se les encarga en todo las conciencias.

24. Ítem que el Juez de bienes no admita demandas del receptor, sino que verifique que las deudas que pide proceden de bienes confiscados pertenecientes por esta razón al fisco, por que sin atender a esto pide el receptor ante el Juez de bienes hacienda suya y no del fisco y admite muchas cesiones y deudas de diferentes personas en su cabeza sin tocarle al fisco y las introduce en la audiencia del Juzgado, sin tener el fisco action ni parte en ellas. Y por este camino se hacen muy grandes vejaciones y se hacen a la audiencia del Juzgado pleitos en gran daño y perjuicio de los del distrito y de la Jurisdiccion Real y no se debe admitir demanda alguna si no fuere por hacienda del fisco, pues no tiene jurisdicción para ello. Y asi se le encarga la conciencia al Juez de bienes y que, no lo cumpliendo, será castigado conforme al exceso.

25. Ítem que no tenga el receptor administración alguna, ni el Juez le pueda nombrar, so pena de privación del oficio a ambos.

26. Ítem las haciendas que deben al fisco réditos de censos corridos y hecha ejecucion y aplicados al fisco por réditos y principal, por no saber quién las compra, nombra el receptor persona que las administre, arriende y cobre las rentas, y este tal ansi nombrado por el receptor lo arrienda, sin que el receptor entienda en ello, ni se de cuenta a los inquisidores. Y el tal administrador lleva de quince uno y tiene obligación de pagar y cobrar aquello en que arrienda. Y de estas administraciones hay muchos delitos contra los administradores y otros contra los arrendadores y tarde se cobra. Y ansí se ordenó que pudiéndose vender las tales haciendas, se vendan, aunque se pierda en la venta de ellas, poniéndolas a pregón, rematándolas a candela al más dante. Y que, para la disposición de esas haciendas, el receptor de cuenta a los inquisidores en Junta de hacienda y que con su acuerdo haga lo que mas convenga al beneficio de la hacienda y no se pongan en administración, sino que por orden del receptor se arriende la tal hacienda en seguras y las cobre de los arrendadores y se excusara lo que lleva el administrador y los pleitos que los dichos administradores causan por no pagar y los arrendamientos los haga el receptor precediendo pregones y a la candela ante el escribano y hechos los tales arrendamientos se pondrá la razón en el libro de la hacienda del fisco por el notario de secrestos, para que se tome cuenta al receptor de lo que de la dicha hacienda procediere. $Y$ en ninguna manera permitan los inquisidores que se ponga en administración hacienda que esté obligada al fisco, sino que se arriende a 
persona segura por cuanta del receptor y, si hay mas interesados, con asistencia de todos, para que no haya engaño y se haga con toda satisfacción. Y ansí lo hagan guardar y cumplir los inquisidores, como les corre obligación.

27. Ítem atento las personas que van a hacer las execuciones con mandamiento del Juez de bienes por rentas del fisco, en cada lugar que hay muchos deudores llevan de cada deudor por entero el salario, de suerte que si llevan diez mandamientos contra diferentes personas y cada uno debe de salario a quinientos maravedíes, los lleva de cada uno enteramente, lo cual es grande agravio para los deudores. Y ansí se ordena que los días que tardo de llegar al tal lugar y los que en el se ocupó, se repartan en cada deudor pro rrata y según la cantidad que cada uno debiere; y que el repartimiento se haga ante escribano y recibida la paga de carta de pago en los papeles del repartimiento y los mismos deudores ante el escribano digan que no han pagado más. Y estos papeles se presenten ante los inquisidores, para que vean si se hizo agravio a los deudores y habiéndolo le castiguen y satisfagan a los agraviados haciendo justicia. Y en todos los mandamientos ponga el notario el salario que se le debe, conforme a la escritpura de obligación.

28. Ítem se ordena que, de aquí adelante, ningún inquisidor en particular para sí, ni para otro ministro, pueda dar licencia para cortar leña en las dehesas, sino que se pida en el Tribunal y los inquisidores la den expresando en ella las cargas que han menester para su casa el inquisidor o oficial que pidiere la licencia; y que la haya de traer criado suyo y con su cabalgadura, u otro por su alquiler y no de otra persona. $Y$ que guarden en cortar las Ordenanzas, sin exceder, y que la licencia que no fuere del Tribunal y refrendada de uno de los notarios del secreto, no se obedezca y se dé noticia de ello a los dichos lugares. Y que al criado que hiciere daño y cortare contra las Ordenanzas, le castiguen los inquisidores, de suerte que echen de ver los dueños de las dehesas que se castigan los excesos y no puedan prender a las guardas, ni llamarlas al Tribunal por las relaciones de sus criados que, de ordinario, son falsas y dan ocasiones a las guardas a que hagan demostraciones con ellos. Lo cual cumplan y hagan cumplir los inquisidores con toda puntualidad, sin dar lugar a que haya más quejas, pues tanto importa a la autoridad del Santo Oficio y suya que no las haya; no dando ocasión a que se les quite la permisión que hay de que puedan traer leña con sus cabalgaduras y criados.

29. Ítem ansimismo ha habido grandes quejas de la libertad con que vivían los criados de los inquisidores y el poco cuidado que tienen en reprimirlos y hacer que vivan con recogimiento sin ofender a nadie; y que exceso ninguno de sus criados castigan y que, ansimismo, sus despenseros en las carnicerías y pescaderías y demás lugares públicos, sobre las preuisiones de mantenimiento de las casas de sus amos, hacen grandes excesos, no contentándose con llevar la carne para sus amos sin hueso, sino que toman cantidad para proveer las casas de especieros y bodegueros y de otras personas y por llevársela sin hueso llevavan cada mes un tanto y para cumplir con estas obligaciones, después de haber llevado para sus amos, quitan con la autoridad y nombre de los inquisidores, la carne, pescados y otros mantenimientos que la Justicia y Regimiento tienen señalados para las personas principales de la villa; y los sábados llevan las cabezas, menudos y lenguas de vacas, diciendo que todo es para sus amos; y porque los 
carniceros y demás personas del Gobierno de la villa ven que no es para los inquisidores, sino para los bodegoneros y tenderos y los reprehenden, se quejan a sus amos diciendo no les quieren dar lo que han menester para sus casas, y creyéndoles prenden a los carniceros y proveedores de bastimentos y los maltratan sin averiguar la verdad, de que se siguen muchas pesadumbres y encuentros con las Justicias. Y para que cesen, se encarga a los inquisidores que procuren reprimir sus criados y que no hagan agravio y viban con el recogimiento que deben y que sus despenseros no puedan conmprar mantenimeintos algunos sino para sus amos y castiguen al que lo contrario hiciero y porque algunos dan crédito a lo que sus criados les dicen y más de semejantes quejas estén advertidos de no las creer. Y cuando el caso pide reparo, den cuenta a sus colegas para que, hecha información, se ponga el remedio necesario. Y porque de ordinario por los criados de los inquisidores suelen suceder muy grandes disgustos y contenciones y hacen entre los mismos inquisidores, se les encarga mucho los castiguen y repriman cualquier exceso, pues tanto importa que no haya quejas de los inquisidores y ministros del Santo Oficio y sus criados, como hasta aquí las ha habido.

30. Ítem porque las quejas que ha habido de no hacer Justicia en los daños que hacen los oficiales con sus ganados y en cortes de leña, se ordena que, de aquí adelante, hagan justicia a cualquier persona que pidiere en la Inquisición cualquier dado guardando las Ordenanzas de la villa que guarda la Justicia Real en la administración de estos casos. Y que envíen cada año, con la relación de las causas, aparte relación de qué pleitos ha habido de penas y qué se ha proveido en ellos, para que el Consejo sepa lo que se hace. Y hagan noticia a la Justicia real y Regimiento como, en esta conformidad, se administrará justicia. Y que fuera de estos ganados y labranza, no puedan tener otros tratos ni contratos los oficiales de la Inquisición.

31. Ítem que lo que hubieren de meter los oficiales de la Inquisicion para sus bastimientos y de sus casas, lo metan por la puerta de la villa que meten los demás y que, en el vino de sus cosechas, no oculten la sisa de Su Magestad, pues la paga el que lo compra.

32. Ítem que el gobernador y Regimietno de la villa de Llerena se han quejado de que los inquisidores no dan lugar a que el hortelano que tiene arrendada la huerta de la Inquisición le ponga postura en el precio de la fruta y lo demás que en ella coge, sino que venda a como pudiere. Y que ansí mismo se recoge en la huerta gente perdida y facinerosa a jugar todos juegos y que no dan lugar que entren los ministros de Justicia a prenderlos, y de todo se siguen grandes daños.

Se ordena que no impidan que al hortelano se le pongan las posturas a los precios de la misma manera que a los demás hortelanos, sin que por ser el hortelano de huerta de la Inquisición sea mas vejado, ni mas exento que los demás. Y que ansí mismo, no permitan los inquisidores en la dicha huerta, entrar a jugar, ni a otras cosas, y juntarse gente perdida y facinerosa, y si los ministros reales pidieren licencia para sacar los de la dicha huerta, se los permitan sacar sin impedimento alguno; pues el Tribunal del Santo Oficio no ha de encubrir en sus casas gente de tal condición, ni impedir la buena administración de la Justicia. 
33. Ítem atento que por los procesos de fe parece que los adbogados, concluidas las causas, se conciertan con los reos en razón de sus salarios y dan cédula en que dicen se tienen por contentos de la protección del tal preso, sin decir lo que llevan y que es una introduction no usada en causas de fee en el Santo Oficio.

Se ordena que, de aquí adelante, no den lugar los inquisidores a que los advogados pidan sus salarios a los presos, sino que, cuando se manda hacer la cuenta de cada preso, señalen los inquisidores lo que an de cargar al preso para el abogado por mano del despensero, recibiendo carta de pago para que se ponga en el proceso.

34. Ítem porque se ha introducido en esa Inquisición echar algunas penas pecuniarias a algunas personas por algunos excesos para gastos de la capilla y se gasta en lo que a los inquisidores parece y conforme a las ordenes y Instructiones del Santo Oficio, todas las penas pecuniarias que se echaren, han de ser para gastos del Santo Oficio.

Se ordena que, de aquí adelante, no puedan imponer penas pecuniarias, sino para gastos del Santo Oficio, de donde se proveen los gastos necesarios para el altar y ministerio de la misa; guardando las Instructiones y Cartas Acordadas.

35. Ítem porque han introducido los inquisidores dar a los oficiales que tienen grangerías de ganados, licencia y mandamientos para que sus ganados puedan andar libremente por todo el distrito de la Inquisición y repostar en todos los pastos, sin pena alguna, como si fueran vecinos de cada lugar de toda la provincia, no obstante que, por carta del Consejo, de 26 de agosto de 1609, están prohibidas semejantes licencias y mandamientos y por no haberse cumplido ha habido grandes quejas de los agravios que han recibido muchos lugares del distrito de la dicha Inquisición.

Se ordena que, de aquí adelante, no se den semejantes licencias y mandamientos y que los notarios del Secreto no los refrenden.

36. Ítem atento que las escritpuras de censos, pheudos y otras rentas de la dicha Inquisición, a muchos años que no se han reconocido por los censalistas y deudores, y con el discurso del tiempo faltan las hipotecas y los obligados y pasan las haciendas en otros poseedores y ha habido en esto gran descuido.

Se ordena que, con toda brevedad, hagan los inquisidores que se reconozcan por las partes todas las dichas escritpuras y se renueven las hipotecas que se tuvieren perdidas y que ansí la razón de los censos, como de los pheudos, se ponga en un libro asentando en él principal y réditos y el día de la paga, mes y año, y la persona que ha de pagar y si la cobranza es en salario y la cantidad de él, poniéndolo con toda claridad para que de este Libro pueda sacarse la razón para cobrar y hacerse las diligencias necesarias y tengan los inquisidores un quaderno de la razón de esto, para que, visto en la Junta de hacienda, sepan lo que falta por cobrar y la causa; y el receptor tendrá otro y el libro principal adonde ha de estar la claridad de todo, le ha de tener el notario de secrestos y se encarga mucho se cumpla con puntualidad por que ha habido muy gran falta en esto. Los quales capítulos se han de leer y publicar estando todos juntos en la Sala del Secreto, para que llegue a su noticia y nadie pueda pretender ignorancia y cada uno observe por su parte lo que le tocare de ellos y de su lectura y notificación se enviará testimonio al Consejo. En Madrid, 24 de noviembre de 1620.

[AHN, Inquisición, libro 1231, ff. 204r-213r] 
IV.6. Recomendaciones del visitador Fabián de Cabrera en 1697

De la Sumaria de la Visita que he hecho en la Inquisición de Llerena, por mandado de V.A. y de lo que fui extrajudicialmente informado y reconoçí a vista de oxos, me a parecido proponer a V.E. los reparos siguientes, sobre que probeherá V.A. lo que más fuere servido:

1

que se comience el offo con la misa sin dilasion en la primera hora de Audiencia 2 hágase assi 3 hágase

4 moderanse los quarenta reales a dos ducados
Lo primero, que sin hallarse vn Inquisidor presente en la Sala del Tribunal, a cuyo lado derecho está el altar algo más de a la mitad de la Sala, no se comience a decir la misa y que, si por hauer tardado en llegar al principio de la ora en que ajustadamente deue començar la misa se dilatare el deçirla, aya atención a adelantar la asistencia a los despachos del Oficio el tiempo que se atrasó la misa por no hauer se començado al principio de la ora.

Que los hedictos de libros que se mandan recoger o corregir, se remitan a los lugares del distrito de la dicha Inquisición, por lo menos a los mas populosos, pues de no hazerse así y de leherlos solo en Llerena, o en muy pocos de su partido, no se cumple el intento de V.A. y la causa que lo motiva se queda en su mismo ynconbeniente.

Q los reconçiliados, que están en carçel de penitencia cumpliendo la que les a sido ynpuesta, no vayan solos a oyr misa los días de fiesta, pues el alcayde de dicha cárçel, que lo es el portero, y tiene posada en ella, debe él llebarlos a cunplir semexante obligación, como lo solía hazer. Y que los áuitos petinenziales los traigan sienpre sobre sus vestiduras dichos penitenciados, por hauerse reconozido omisión y defecto en lo contenido en este capitulo.

Que supuesto que no pagándose en todas Inquisiciones de los más de pretendientes derecho alguno a la Cofradía de San Pedro Martir y que en la de Llerena, hauiéndose pagado doçe reales de cada pretendiente para este fin hasta los diez y siete de Julio de 638, por Auto del Tribunal ha subido este derecho a quarenta reales, se escuse de aquí adelante que vno de los Inquisidores, despues de despachados dichos pretendientes, en los llame a su quarto y pida graciosamente nueba cotribuzion para la dicha Cofradía, por pareçer açción muy gravosa en la miseria de estos tiempos y cortedad de caudales, especialmte en los lugares de aquel distrito, que hauiendo dado con efecto dichos quarenta reales ayan de contribuir de nuevo a quatro y a seis ducados cada uno de dichos pretendientes, como se a introduzido de dos a tres años a esta parte. 
5

como se dize

6

como se dize

7

como se dize
Que no se despachen comisiones de prueuas de limpieza de sangre a los ministros que las an de hazer sin que primero conste al pie de la zédula de déposito, acordado por el Tribunal, del resçibo del depósito de ellos y que esta materia no se gouierne en confiança, por fauor o crédito de oficia,l o persona superior del Tribunal, con aperçiuimiento que el notario del Secreto que hiziere dicho despacho y el juez que lo firmare, serán executados por la cantidad de maravedíes que se ouieren causado de costas en dichas informaciones, no hauiendo remitido dicha zédula al depositario y que del suso dicho se hará la misma cobranza si ouiere puesto el arescibo de dichos maravedíes, avnque no le ayan sido entregados siruiendo se V.A. de estrechar más este mandato sobre los que hasta aquí an venido en esta razon por V.A.

Que ningún oficial de la dicha Inquisición se encargue de cobrar por los comisarios o notarios los derechos que le sean deuidos de informaciones, ni reciban dinero ninguno de los pretendientes con pretexto de dexarlo en poder de qualquiera de dichos oficiales para quando se les mande depositar, pues pueden dichos pretendientes valerse de otro medio para en la dicha sazón, sin el inconveniente que se a reconoçido yrresulta de lo contrario, en conformidad de lo dispuesto por Carta acordada de veinte y uno de Henero de 620.

Que por quanto está dispuesto por Instruziones i Cartas Acordadas que a las prisiones con sequestro de vienes se hallen el receptor y notario de secrestos con el alguacil mayor y de no practicarse lo mesmo en las que se mandan hazer de carçeles secretas con envargo de vienes, se a rerconozido, hauiéndose hecho dichos envargos sin autoridad de notario, la presunzión de que se ocultaron en parte los dichos vienes, de manera que, gastados en alimentar al reo, a suplido la hazienda del fisco lo necesario para sustentarlo hasta que se despacha su causa, siendo lo este defecto de que el receptor Juan Gómez Escudero pusiese demanda de doce mil seiscientos y veinte y tres maravedíes a don Diego de Chabes, alguacil mayor, porque hauiendo preso a Francisca Sánchez Saluadora, vezina de Llerena, con envargo de vienes, no hizo dicho envargo con autoridad de notario y suplió el fisco dicha cantidad en alimentar a la rea despues de gastados los vienes que la fueron hallados, se sirua V.A. de mandar que dichas Instruziones i Cartas Acordadas se entiendan así mismo en las prisiones de cárceles secretas con envargo de vienes, o que por lo menos el Tribunal prouea de notario ante quien pasen los dichos envargos, pues quando de ellos no resulte vtil al fisco, es notorio lo que se les sigue de no grauarle en los maravedíes que escusará de suplir si se entiende hazerse los envargos con dicha 
8

como se

dize, renouando

las zensuras

y penas de

las cartas

acordadas

9

como se dize

10

como se dize

con fiança

bastante a

arbitrio del

tribunal

11

como se dize solemnidad en mayor seguro de que pueda hauer mas vienes con que alimentar los reos.

Que siendo precisa la Junta de Hazienda el vltimo día de cada mes, para sauer el estado de ella y de sus pleytos, cobranzas y los tienpos que puede ser a propósito para la mexor disposición de los frutos de las canongías de Plasenzia, Ziudad Rodrigo, Coria y Vadajoz, como parte tan sustancial en caja administración y conferencia de los ministros, se asegura más el acierto y cada qual de ellos se governara atento al cumplimiento de lo que le tocare en orden a este fin tan preuenido para su inviolable obseruancia por Instruziones y Cartas Acordadas de V.A, de 19 de agosto de 569, 19 de nouiembre de 588 y 2 de mayo de 622 . Y hauiendo se reconocido notable omisión en esto, sea seruido V.A, de mandar se cunplan con efecto dichas Cartas Acordadas, con las zensuras late sentençie de la referida de 19 de nouiebre de 588, pues en la conseruazión de la hazienda del fisco queda asegurado en sustento de los ministros, que con su asistençia y trabajo sirben tanto a Nuestro Señor y a V.A.

Que los procesos de fe y causas criminales e Ynformaziones de limpieza, cuya notizia es forçoso tengan el fiscal y notarios del Secreto para quando se les pida razon de ellos y ayan de proseguirse y fenecerse, estén en la Cámara del Secreto como lugar deputado para esto y demás seguridad, sin que se permita puedan estar menos que debaxo de las tres llabes de dicha Cámara, por hauer se reconoido el abuso de tener el Inquisidor maás antiguo de Llerena, en su caxón de la mesa del Tribunal, muchas causas y papeles de la calidad referida, sin ningun fruto y con muchos inconvenientes en la contingencia de quebrantarse dicho caxón experimentada en la causa criminal que ha seguido el fiscal de aquella Inquisición contra Agustin Vidal, portero de ella y que V.A. se sirva mandar de nuevo con çensuras y pena pencuniaria se obserue materia tan importante.

Que las alajas del Tribunal, los ornamentos y plata de su Capilla, cuyo manexo ha corrido hasta aquí por el portero, no se le entreguen sin fiança respectiba al valor de ellas, porque deterioradas o en la falta de alguna de dichas alajas por su culpa, es dificultosa la satisfacción respecto de ser cortos sus gajes y preciso al parecer el socorrerle con ellos por ser alimentos y no tener de ordinario otro caudal los que van a seruir el dicho oficio, reconoziéndose este inconveniente en la causa que el fiscal a segudio contra el dicho oortero zerca de dichas alajas.

Que por hauer se introduzido en la dicha Inquisición, de dos años a esta parte, el despacho de peticiones solo en los lunes, miércoles y viernes de la semana, con el inconveniente que resulta de la dilazión 
12.

como se dize

13

como se dize

14

como se

dize,

con pena de

veinte

ducados al

que faltare a

cumplimient

o de lo

referido en

dichos

capítulos

por lo que

les tocare la

obseruançia

de ellos de las causas y excesiva costa de los litigantes y en especial de los que se hallan fuera de sus casas, vexados y molestados con semexante gouierno, se a seruido V.A. de mandar se reforme esta nouedad y guarde la costumbre antigua de despachar dichas peticiones todos los días.

Que los procuradores de dichas causas no entren personalmente en el Tribunal las peticiones de sus partes, pues en ellas se refiere lo que puede decir y alegar, antes bien se hordene al portero lasrreciba y entregue en el Tribunal, haziendo para ello señal con la canpanilla de afuera. Y los Inquisidores cuyden mucho de despachar las quanto antes aya lugar y que el notario del Secreto ante quien se decretaren, las dé a dichos procuradores luego que salga del oficio, para que les conste el estado de sus pedimientos y los prosigan como más les convenga.

Que no se reçepten ni admitan en las casas de la Inquisición o huerta de ella, ni en otras de los oficiales, que, por serlo, son de autohoridad y respecto, personas retraídas por delictos que ayan cometido siruiéndose V.A. de renouar con aprieto la disposizión de la Carta Acordada de 24 de nouiembre de 620, en conformidad del capítulo 32 de la Visita que en dicho año hizo el inquisidor doctor Don Miguel Sanctos de Sanpedro en la dicha Inquisició,n con que se escusarán graues inconvenientes y estará por este medio mas sigura la buena administración de Justizia

Que con efecto y sin dilazion ni escusa alguna disponga el Tribunal se reconozcan por las partes los censos del fisco y se renueben sus ypotecas, por hauer se reconoçido de la práctica la ynspección hecha en esta ultima Visita de los Libros de su Contaduría que están por reconozer ochenta y dos censos y que la misma diligencia se haga con los que se reconoçieron de veinte años a esta parte por las contingencias de hauer pasado a tercero poseedor la obligacion de pagarlos. Y que asimismo aya particular cuidado en reconoçer i conseruar las fincas de veinte censos que están en administración por el fisco, para que, por este medio, se asegure más la cobranza de ellas, siruiendo se V.A. de mandar, con la estrecheza posible, el cumplimiento de todo lo referido en esta propuesta por las raçones que obligan y ser los dichos censos la parte más sustancial de la hazienda de la dicha Inquisicion. 
15

véase la

carta del

conde de

Saluatierra, comendador

de los

Santos, del

Horden de

Santiago,

fol. 685 de la

Sumaria

véase a Don

Diego de

Chaues, fol.

299 de la

sumaria

iten a Juan

de Vera, fol.

651 de la

Sumaria

Juntense los

papeles que

ay en el

Consejo en

esta razón

para

proueer lo

que más

convenga
Por quanto en los años caros, por la cortedad de los frutos, los inquisidores de Llerena an hecho para sí y los demás oficiales repartimiento del trigo y ceuada en los diezmos de las encomiendas, con notable quexa de los que las poseen, porque administradas por ellos, o dadas en arrendamiento, se reconoce con euidencia la quiebra de su valor, subjetándolas a dicho repartimiento y de ordinario están dichas encomiendas en los grandes y títulos de estos Reynos y como dignidades eclesiásticas, parece deben limitar en ellas la ezepcion que en las preuendas que constan de frutos de la misma calidad sea seruido V.A., pues la distancia de los que pertenezen a las quatro canonjías de Plasenzia, Ciudad Rodrigo, Coria y Vadaxoz, no dá lugar a valerse de ellos, pagándolos a la tasa, de mandar a los Inquisidores que, de aquí adelante, ofreciéndose el caso de continuar dichos repartimientos, sean y se entiendan con las personas en quienes los an hecho asta aquí y escusen a las dichas encomiendas de semexante pensión, por euitar los enpeños con el Tribunal y el enbarazo que pueden causar a V.A. los dichos comendadores, que oy con modestia lo sienten y representan y se a reconocido por carta del conde de Saluatierra de diez y siete de diziembre de 639, a fol. 685 de la Sumaria de esta Visita, quejándose del agrauio hecho de horden de aquel Tribunal adminisrador de su encomienda de la Villa de los Santos, seis leguas de Llerena; y consta de la deposizion de don Diego de Chaues, f. 299 y el alcalde Juan de Vera, vezino de esta, administrador de la encomienda de Medina de las Torres, f. 651, de dicha sumaria de que he dexado de hazer cargo a los inquisidores remitiendo a la consideracion de V.A., para el remedio que fuere seruido poner en esta materia. $=$ Fabián Cabrera.

$=$ 